\title{
A Decomposition of Growth of the Real Wage Rate for South Africa: 1970 - 2000
}

\author{
Dipak Mazumdar \\ University of Toronto \\ E-mail: mazumdar@chass.utoronto.ca
}

Dirk van Seventer

Trade and Industrial Policy Strategies

E-mail: dirk@tips.org.za 


\section{Abstract}

This paper examines the potential trade-off between growth in employment and growth in wages. In order to assess the trade-off between employment growth and real wage growth, we make use of a simple decomposition model, following Mazumdar (2000), in which real wage growth is determined by growth in real value added, employment growth, a trend in the wage share of value added and a relative price effect.

\section{Acknowledgements}

This paper is the eighth in a series of research outputs related to a two-year project entitled Understanding Labour Demand Trends and Patterns in South Africa, housed within the Development Policy Research Unit. This research paper is funded by USAID and administered by the Joint Centre for Political and Economic Studies Inc. under Subcontract No. JCNAT98-954-08-00 from Nathan Associates Inc. Their generous financial assistance in this regard is acknowledged.

We would like to thank Haroon Bhorat and Rashad Cassim for their helpful comments and suggestions.

The views expressed herein are those of the authors and not necessarily those of the DPRU or USAID.

Development Policy Research Unit Tel: +27216505705

Fax: +27216505711
Information about our Working Papers and other published titles are available on our website at: http://www.uct.ac.za/depts/dpru 


\section{Table of Contents}

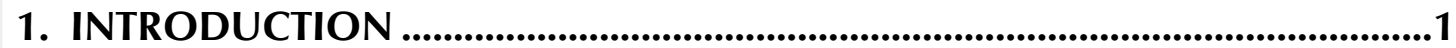

2. A REAL WAGE GROWTH DECOMPOSITION MODEL..................................1

3 RESULTS OF THE DECOMPOSITION OF REAL WAGE GROWTH IN SOUTH

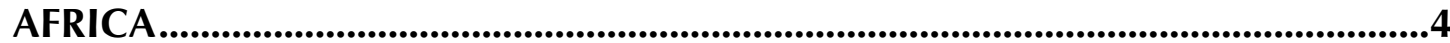

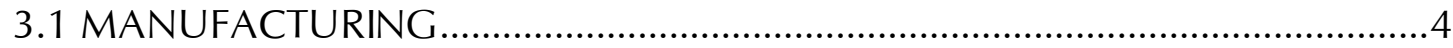

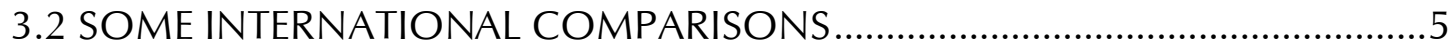

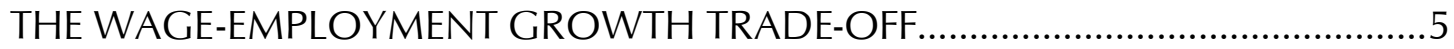

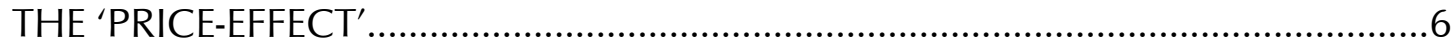

3.3 EXPLAINING CHANGES IN THE WAGE-EMPLOYMENT TRADE-OFF .............7

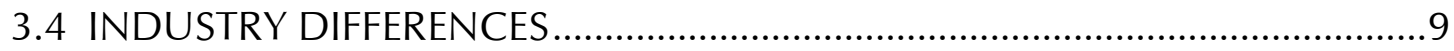

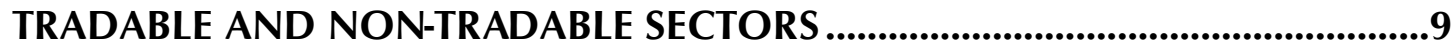

DIFFERENT GROUPS WITHIN THE MANUFACTURING SECTOR..................... 13

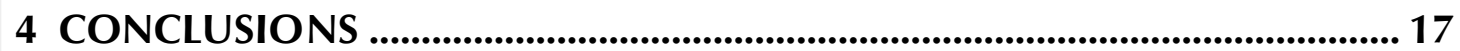

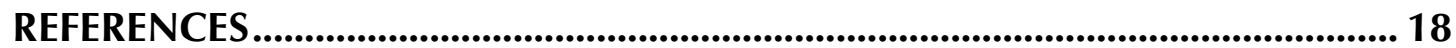

APPENDIX A: DETAILED INDUSTRY RESULTS ........................................................1 


\section{Introduction}

Recent experience with economic liberalisation and globalisation in South Africa has, according to some economic observers, contributed to the phenomenon of "jobless growth". While several external explanations have been advanced, a central issue is the potential trade-off between growth in employment and growth in wages. In this regard, a very crude distinction can be made between neoclassical views of the SARB and the World Bank and demand or wage led growth models of the MERG (Gibson, 2000). In the former, the crucial issue is getting prices right, i.e., in line with factor availability. If wages rise beyond the increase in labour productivity, entrepreneurs will substitute capital for labour in a seamless way and employment growth will respond through an inverse functional relationship underpinned by the principals of micro firm behaviour and the associated production function.

In demand or wage led growth models, the causality runs the opposite way. With low capacity utilisation, so that demand matters, rising wages could become the engine of growth in itself, although this will depend on a number of other factors such as the strength of the accelerator mechanism of investment and inflationary expectations and the impact on export competitiveness (Gibson, 2000: 146). Other considerations are labour market institutions and macroeconomic policy.

Although these concerns require a general equilibrium framework for proper evaluation, it is perhaps also useful to examine past trends in the South African economy. In order to assess the trade-off between employment growth and real wage growth, we make use of a simple decomposition model, following Mazumdar (2000), in which real wage growth is determined by growth in real value added, employment growth, a trend in the wage share of value added and a relative price effect.

We start with an exposition of the decomposition model in the next section. This is followed by a presentation of the results. We conclude with some summary remarks and suggestions for further research.

\section{A Real Wage Growth Decomposition Model}

The relationship between the wage bill, $S_{w}$ and value added, $V$, both in current prices, can be expressed in the following way:

$$
S_{w}=V^{\alpha}
$$

in which $\alpha$ is a technological and behavioural parameter which is assumed to remain constant over the period of observation. If $\alpha$ is equal to unity the share of wages remain constant, while a value higher than unity suggests that the wage bill increases relatively to value added and the share of gross operating surplus declines. In relative terms we can then write: 
(2)

$$
\frac{d S_{w}}{S_{w}}=\alpha \frac{d V}{V}
$$

or

$$
\hat{S}_{w}=a \hat{V}
$$

So that if $\alpha$ is equal to unity, the nominal wage bill grows just as fast as nominal value added, while a value higher than unity suggests that the wages bill grows faster than value added and the share of the wage bill in value increases relative to the share of gross operating surplus or capital.

Growth in nominal value added can also be written as the sum of growth in real value added and the change in the producer price index. Using the same percentage change notation as in equation (2), this can be expressed as follows:

$$
\hat{V}=\hat{v}+\hat{P}
$$

In which $\hat{v}$ is the growth in real value added and $\hat{P_{p}}$ the change in the producer price index, or the producer price inflation rate. Similarly, growth in the nominal wage bill can also be written as the sum of the growth in the real wage per worker, the change in the consumer price index and growth in employment, hence:

$$
\hat{S_{w}}=\hat{w}+\hat{P_{c}}+\hat{L}
$$

In which $\hat{w}$ is the growth in the real wage rate, $\hat{P}_{c}$ the change in the consumer price index, or consumer price inflation and $\hat{L}$ the growth in employment. Combining equations (2) and (3) we can write:

$$
\hat{S_{w}}=\alpha\left(\hat{v}+\hat{P_{p}}\right)
$$

and combining equations (4) and (5) yields: 
(6)

$$
\begin{aligned}
& \hat{w}+\hat{P_{c}}+\hat{L}=\alpha\left(\hat{v}+\hat{P_{p}}\right) \\
& \hat{w}=\alpha\left(\hat{v}+\hat{P_{p}}\right)-\left(\hat{P_{c}}+\hat{L}\right) \\
& \hat{w}=\alpha \hat{v}-\hat{L}+\left(\alpha \hat{P_{p}}-\hat{P_{c}}\right)
\end{aligned}
$$

Growth in real wages per worker can thus be seen to be equal to an output effect, $\alpha \hat{v}$, minus an employment effect, $\hat{L}$, and a price effect, $\alpha \hat{P_{p}}-\hat{P_{c}}$. The latter can be further decomposed so that equation (6) can be rewritten as:

$$
\hat{w}=\alpha \hat{v}-\hat{L}+(\alpha-1) \hat{P_{p}}+\left(\hat{P_{p}}-\hat{P_{c}}\right)
$$

in which $(\alpha-1) \hat{P_{p}}$ is known as the wage share effect, while $\hat{P_{p}}-\hat{P_{c}}$ is seen as the domestic real exchange rate. The third term of equation (7) is only negative if $\alpha$ is negative, i.e., if the wage share of value added is declining. This means that real wage growth is negatively effected since, with a declining wage share, the increase in the producer price, $\hat{P_{p}}$, is to a larger degree appropriated by capital, in the form of gross operating surplus. If, in the fourth term, consumer price inflation (which is associated with non-tradable goods) is higher than producer price inflation (which is associated with tradable goods, hence the term domestic real exchange rate), real wage growth is also eroded.

To recap, real wage growth can be decomposed into 4 additive elements:

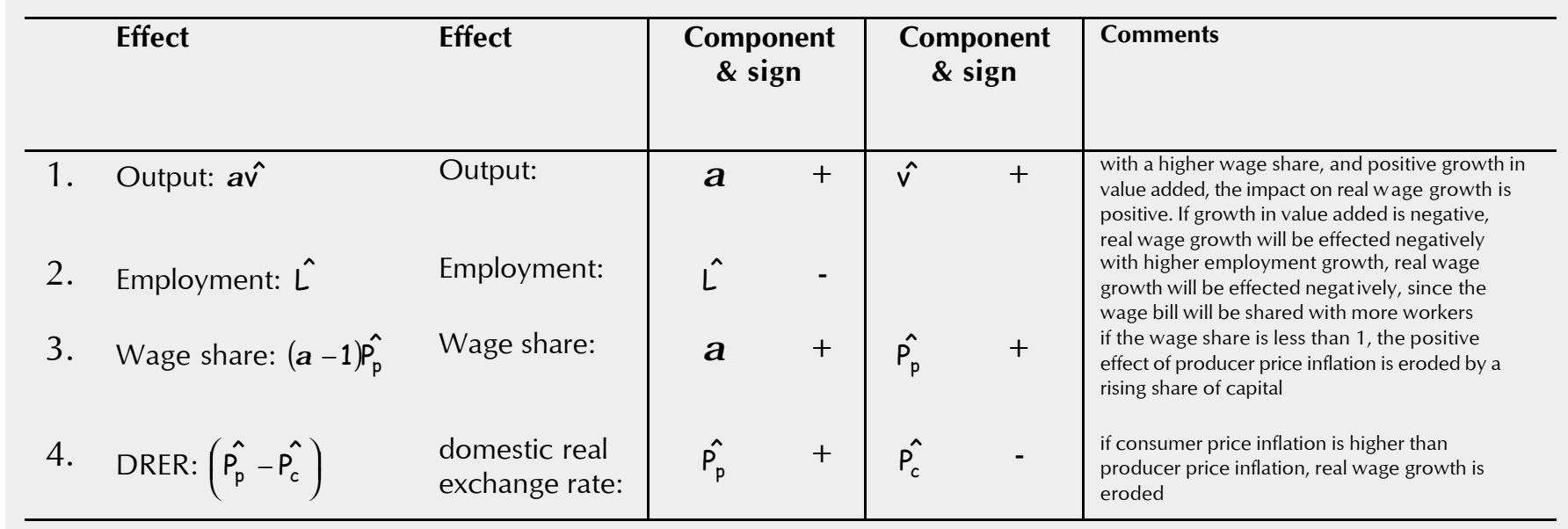




\section{Results of the Decomposition of Real Wage Growth in South Africa}

In this section we discuss the results of the decomposition of real wage growth in South Africa. We start with an analysis of the South African manufacturing sector as a whole. This is followed by an international comparison after which we attempt to explain the changes in the wageemployment trade-off at a more detailed sub-sector level. For reasons of convenience, we present weighted average annual growth rates for the 1970s, 1980s the $1^{\text {st }}$ half of the 1990 s and the $2^{\text {nd }}$ half of the 1990s.

\subsection{Manufacturing}

We start our discussion of the decomposition of real wage growth over the period 1970 to 2000 by examining the results for manufacturing as a whole. From Table 1 it appears that the major change after the 1970s is the sharp decline in the growth rate of real output, falling to a low positive value in the 1980s, and becoming increasingly negative in the 1990s. Over time, the labour market reacted to the falling output by moving away from the 1970s scenario of distributing the gains of real output rather equally between employment increase and wage increase. The distribution tilted increasingly to real wage growth of those in employment at the cost of a slower expansion of employment. In the 1980s the shift, although clearly perceptible, was moderate in extent. It can be seen that there was a slight growth in employment during this period, as real wage growth was negative in response to the growth rate of output falling to just about a quarter of its value in the 1970s. If one takes account of the 'price-effect ', the markedly lower real output growth was almost reduced to zero. The economy's response to the nearly constant size of the 'cake' to be divided between wage and employment growth was to achieve a slightly positive employment growth ate of $0.3 \%$ per annum, offset by an almost equivalent rate of decline of the real wage.

In the decade of the 1990s, however, the trade-off changed increasingly towards real wage growth. In the first half of the 1990s a nearly identical rate of 'net' output growth led to a negative employment growth rate of $1.2 \%$ per annum, balanced by a real wage growth rate of an equivalent amount. This trend was reinforced in the second half of the 1990s. In spite of an even smaller rate of output growth $(0.5 \%)$ - reinforced by an adverse price-effect - real wage increase was bumped up to a whopping $3.9 \%$ and had to be balanced by a fall in employment. The increased share of wages in value added could do no more than slightly mitigate the rate of fall in employment - given the high rate of real wage growth. The result was a very sharp decline in the rate of employment - at the rate of $3 \%$ per annum. However, with falling domestic demand or external processes such as trade liberalisation leading to higher competitiveness - are we correct to argue that the very sharp decline in the rate of employment is indeed "the result" of the high rate of real wage growth and not due to factors originating in the product markets? We have one answer already and that is that the decline in employment growth was much larger than the fall in the growth rate of output. 
Table 1: Decomposition Exercise for Real Wage Growth, All Manufacturing

\begin{tabular}{|c|c|c|c|c|c|c|c|c|c|}
\hline Period & $\hat{w}$ & $\hat{v}$ & $\hat{L^{n}}$ & $\hat{P_{p}}$ & $\begin{array}{c}\text { DRER }= \\
\hat{P}_{p}-\hat{P}_{c}\end{array}$ & $\alpha$ & $\begin{array}{c}\text { Output } \\
\text { Effect }\end{array}$ & $\begin{array}{l}\text { Wage } \\
\text { share } \\
\text { effect }\end{array}$ & $\begin{array}{c}\text { Price } \\
\text { Effect } \\
(5)^{+} \\
(8)\end{array}$ \\
\hline & 1 & 2 & 3 & 4 & 5 & 6 & 7 & 8 & 9 \\
\hline $1970 \mathrm{~s}$ & 2.6 & 4.5 & 2.4 & 12.1 & 0.8 & 0.85 & 4.4 & -0.3 & 0.5 \\
\hline 1980s & -0.4 & 1.1 & 0.3 & 15.2 & 0.4 & 0.90 & 1.0 & -1.5 & -1.1 \\
\hline 1990s I & 1.0 & 1.1 & -1.2 & 9.9 & -0.2 & 0.91 & 1.0 & -0.9 & -1.1 \\
\hline 1990s II & 3.9 & 0.5 & -3.0 & 5.7 & -0.7 & 1.15 & 0.6 & 0.9 & 0.2 \\
\hline 1990s I and II & 1.8 & $1.5^{*}$ & -1.5 & 7.4 & -0.7 & 0.94 & 1.4 & -0.4 & -1.1 \\
\hline
\end{tabular}

Source: TIPS South Africa Standardised Industry Data Base and own calculations.

Note: Variables with a "hat" denote percentage annual rate of growth

Secondly, it can be seen from column (6) that the elasticity of the wage-bill, with respect to value added (the $\alpha$ value), rose slightly in the 1980s and early 1990s, but became larger than unity only in the second half of the 1990s. Compared to the other periods, this made the wageshare effect (shown in column 8) support a faster increase in real wages. The increase in the share of wages in value added, which this trend implies, suggests a change in labour market conditions. Possible reasons for this important phenomenon, in the second half of the 1990s in particular, require more detailed research. Some notes on the various hypotheses are given later.

How did the DRER or the relative rates of increase of producer and consumer price indices behave over the different periods, and did the trends change over the three periods distinguished? It is seen from column (5) that the consumer prices began to rise faster than producer prices as from the first half of the 1990s, reversing its earlier trend, and that this phenomenon was exacerbated in the latter half of the 1990s. This was an important change which implied that ceteris paribus employment growth had to be reduced more to sustain a given growth rate of real wage. In fact, it can be seen from column (9) that, in the second half of the 1990s, the DRER effect practically wiped out the positive wage share effect.

\subsection{Some International Comparisons}

\section{The Wage-Employment Growth Trade-Off}

It has been shown in Mazumdar (2001) that the different regions of the world have shown important divergences in the way the trade-off between wage growth and employment growth has been worked out in their manufacturing labour markets in the 1970s and the 1980s. East Asia, which had the highest rate of growth in real value added in manufacturing, tended to divide its output growth - net of the 'price-effect' - equally between wage and employment growth as indeed South Africa had done in the 1970s. Of the other regions, EEC and Sub-Saharan Africa stood at opposite ends of the spectrum. The outcome of labour market trends in the EEC in both the 1970s and the 1980s was very much in favour of real wage growth: with a modest real output growth in manufacturing the significant increase in real wage growth could only be achieved at the cost of a negative rate of growth of employment. The experience of Sub-Saharan Africa was diametrically opposite. Also in both decades, the region was characterised by a significant positive growth rate of employment. Given the limited output growth, net of the 'price-effect', this meant that the trends of real wage growth were negative in both decades. Indeed the bias towards employment growth at the cost of falling real wage seems to have been exacerbated in the 1980s. 
South Africa in the 1970s behaved much like the East Asian region. Although output growth in manufacturing was nowhere near the level of East Asia, it would appear that South Africa divided the fruits of economic growth equally between wage and employment increase. In the next two decades however, the economy seems to have moved increasingly to the EEC pattern of favouring wage growth for those already in employment, rather than the expansion of employment. As we have seen, this shift really gathered momentum in the 1990s, and became very strongly biased to real wage growth at the cost of employment decline in the second half of the decade. Before coming to some suggestions concerning research, which is needed to throw light on this change in labour market outcomes in the 1990s, we should pay some attention to the impact of the 'price - effect' and, in particular, how South Africa compares with other regions of the world on this point.

\section{The 'Price-Effect'}

We have seen from the algebra of the decomposition analysis that the rate of price increase enters the equation in two different ways. First, the wage share effect is positive or negative as the value of $\alpha$ is greater than or less than unity. But the magnitude of the effect - whether positive or negative - depends on the rate of increase of producer prices. Secondly, the DRER effect is governed by the increase in consumer price (as it affects the workers' real wage) relative to that of the producer price (which affects the producers' real cost of labour).

The first point to note about the South African experience is that the rate of price increase has been moderate. In the 1970s the producer prices increased at more or less the same rate as the median value for Sub-Saharan Africa (Mazumdar 2001,Table 3), but in the 1980s it had pulled ahead. The 1990s saw a deceleration of the price inflation. The impact of this moderate level of price inflation on the wage share effect can be seen by contrasting it with the case of the Latin American and the Caribbean (LAC) region. The value of $\alpha$ in LAC at 0.97 was only slightly less than unity, both in the 1970 s and the 1980s, but because of the high rate of inflation the "leakage" from the real wage bill available to workers was substantial (in excess of $4 \%$ per annum in the 1970s). In South Africa the wage share effect was at its maximum negative value $(-1.5 \%$ per annum) in the 1980s, in spite of the wage elasticity $\alpha$ being so much lower at 0.9 .

A second difference with many other regions is that the DRER effect in South Africa has been so much smaller, because the rate of increase in consumer prices keeping fairly close to the rate of increase in producer prices. In the 1980s, in particular, the rate of increase of consumer prices ran away faster than the increase in producer prices to the extent of $2.9 \%$ per annum in East Asia, $1.6 \%$ in OECD, $4.1 \%$ in LAC, and $3.2 \%$ in SSA (other than South Africa). Against this background, the South African experience of the consumer price increase actually trailing behind the producer price index, albeit to moderate extent of $0.4 \%$ per annum, is positively unusual.

The economics behind this phenomenon - which clearly has to do with the structure of the economy as well as the macro-economic policies - deserves more intensive research. It is worthy to note that in the 1990s South Africa seems to have caught up with the 'usual' experience of consumer prices rising faster than producer prices, but the difference was quite modest even in the second half of the decade. 


\subsection{Explaining Changes in the Wage-Employment Trade-off}

The observation, that the impact of the 'price-effect' on the labour market outcomes is of minor importance, offers us the opportunity to examine the reasons for the changes in the employmentwage trade-off over the last three decades, largely in terms of the changing behaviour of labour markets in South African manufacturing. To recall: the major issues are the increasing share of wages in value added over time (increasing value of $\alpha$ ); and the associated tilt to wage increase at the expense of employment increase. Note that the two phenomena might not go together. If, for whatever reasons wages are pushed up, in a neo-classical model employment will fall, other things remaining equal, but the share of wages in value added will fall only if the elasticity of employment with respect to a wage increase is more than unity. Alternatively, in the Kalecki type of framework, where the share of wages depends on the 'mark up' margin in a cost-plus price model, the wage increase squeezes the margin and leads to a decrease in wage share with no large change in the employment level (The 'degree of monopoly' diminishes). Several hypotheses to explain the tilt to wage increase are possible:

1. There is an increase in capital intensity (the use of capital per unit of labour). This raises the marginal product of labour and hence the wage level, with an inelastic supply of labour, but lowers the share of wages if the elasticity of substitution of labour to capital is more than unity. The increase in capital intensity could be partly explained because of the changing composition of industry (see below). If, however, the increase is pervasive over a wide range of industries, we need to look for explanations of factors which might induce substitution of capital for abour. This is very unlikely because the supply price of at least unskilled labour can hardly have increased with growing unemployment. However, capital might be a substitute not for unskilled but skilled labour. A relative shortage of skilled labour might indeed have developed-in this case the effect merges with the group of factors suggested by the next hypothesis (2). Another possible and perhaps more plausible explanation in the South African context, is a high rate of capital deepening technical progress as reported by Edwards (2000). This might be due to the introduction of new technology, more export orientation, etc. As a result, the productivity of unskilled labour could have increased more than that of skilled labour, which explains, at least to some degree, why the real wage, according to Lewis (2001) has increased more than that of highly skilled labour.

2. There is an increased demand for skilled labour relative to the supply of such labour, pushing up the relative wages of skilled labour. We then need to look at data for skill differentials, and also evidence of the skill composition of the workforce in manufacturing. These trends are confirmed in the next figure.

3. A variant of the skill-based hypothesis is the idea that efficiency wage considerations are pushing the wage up, above the supply price of unskilled labour. Wages might be increasing as the post-apartheid labour policy might be encouraging the development of a better trained and better motivated black labour force.

4. The third group of explanations is institutional. In the crudest form, trade unions or a combination of trade unions and government labour policies might be pushing up wages at the cost of employment expansion. The intention is of course not to reduce employment, but policies might have underestimated the impact of wage increase on employment.

5. A related point is that institutional interventions like labour legislation might have increased the cost of dismissals or layoffs, inducing employers to obtain their labour flow, by increasing 
wage per worker and hoping that the supply of efficiency units of work per worker would increase at least to some extent.

\section{Figure 1: Demand for Labour by Skill Group}

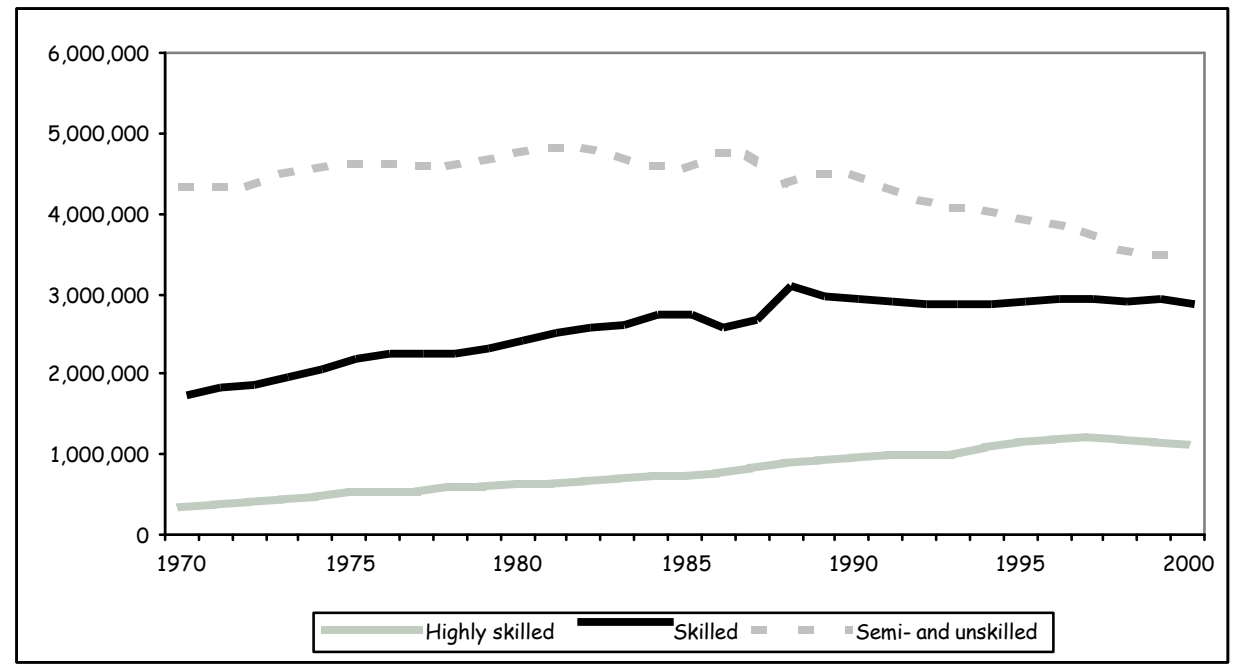

Source: TIPS South Africa Standardised Industry Data Base

The average annual growth rates associated with these trends are shown in the next table.

Table 2: Average Annual Growth Rates in the Demand for Labour by Skill

$\begin{array}{lccc}\mathbf{1 9 7 1 - 2 0 0 0} & 3.9 \% & 1.6 \% & -0.8 \% \\ \mathbf{1 9 7 0 s} & 5.9 \% & 3.2 \% & 0.9 \% \\ \mathbf{1 9 8 0 s} & 4.7 \% & 2.0 \% & -0.8 \% \\ \mathbf{1}^{\text {st }} \text { half } \mathbf{1 9 9 0 s} & 4.0 \% & 0.1 \% & -2.1 \% \\ \mathbf{2}^{\text {nd }} \text { half } \mathbf{1 9 9 0 s} & -0.7 \% & -0.2 \% & -2.8 \%\end{array}$

Source: TIPS South Africa Standardised Industry Data Base:

Highly skilled labour is defined as workers with at least two years of education and training (usually formal) after Standard 10 and includes all professional and semi-professional workers, management and administrative workers and technicians. Skilled labour comprises workers in occupations for which at least a number of weeks or months of training is required in or outside the work environment. In most cases an educational qualification of at least Standard 7 or 8 is required for appointment in these occupations, which usually include clerical, sales and service workers, artisans, apprentices and supervisors. Semi-skilled labour are those workers for which the required expertise is acquired after a short training period (a few days or weeks). Candidates must possess basic literacy and numeracy skills prior to training, while primary education is sufficient as an entry requirement for training. Unskilled occupations are those for which no formal education or training is required. In these occupations induction or orientation courses are not regarded as training. Semi-skilled and unskilled occupations are usually lumped together under the heading lower-level personnel. 
A substantial discussion of the relative importance of the alternative hypotheses given above require detailed research, and is beyond the scope of this paper'. We might, however, draw attention to the conclusion from the evidence on wage behaviour in recent years, pointed out by Lewis (2001) who observes the extraordinary rise in the real wages of the unskilled labour in the recent decade relative to the increase in real earnings of the skilled. "In 1999, real remuneration per highly skilled worker was at $90 \%$ of the 1970 level, while real remuneration per skilled worker increased to $110 \%$ of the 1970 level. In contrast, real remuneration per unskilled and semi-skilled worker in 1999 had grown to $250 \%$ of the 1970 level (p.14). At the same time, the unemployment rate for the unskilled and less skilled groups had climbed relentlessly since the mid-1980s (ibid, Figure 2.2), suggesting that the rapid increase in real wages for these groups took place in spite of the availability of a large elastic supply of such labour. We may then conclude that points 1 and 2 in the list of possible hypotheses given above, explaining the tilt in the tradeoff to wage increase, must be rejected. We are then left with the last three hypotheses, based on efficiency wage mechanisms or institutional factors. These two forces often go hand in hand. It is therefore difficult to separate their relative importance without much detailed statistical and historical research, making use of firm level data as well as industry-wide time series. It has been found in research, reported for other parts of Sub-Saharan Africa, that even though institutional factors might appear to be dominant as proximate causes of the wage increase, efficiency wage considerations might be more important than appears at first sight (Mazumdar 2002, especially chapters 6, 14 and 16). Separate analysis by firm size groups is an important step in disentangling the causal factors behind wage growth.

\subsection{Industry Differences}

We now discuss the possibility hat the results discussed above for all manufacturing might be different across industry groups.

\section{Tradable and Non-tradable Sectors}

A basic difference is sometimes made between the tradable and the non-tradable sectors in the economy. The idea is that the tradables (comprising agriculture, mining and manufacturing) are more exposed to foreign competition and hence wage behaviour might be more sensitive to market pressures. Non-tradables (including electricity, construction and services), are expected to be much more influenced by domestic institutional pressures. This distinction in the South African context is at best marginal. With a protectionist trade policy, which has only recently been liberalised, it is doubtful how much of the tradable sector was really part of the world market. Secondly, the service sector includes some types of activities that are increasingly part of the external sector. Nevertheless, in so far as competitive pressures might differ to some extent between these broad sectors, it is interesting to see if the wage-employment trends were any different between the sectors. This is especially true in so far as the growth rates of the two sectors, having run fairly close together in the 1970s, began to diverge in the 1980s, and became large in the 1990s as the tradable growth rate fell off.

\footnotetext{
${ }^{1}$ For a review of the theories in the labour literature on the way the trade-off between employment and wage increase might work out, see Mazumdar (2001)
} 
Table 3: Growth Rates of Real Value Added by Sectors.

\begin{tabular}{lcccc}
\hline Industry & $\mathbf{1 9 7 0 s}$ & $\mathbf{1 9 8 0 s}$ & $\mathbf{1 9 9 0 s - 1}^{\text {st }}$ half & 1990s-2 $^{\text {nd }}$ half \\
\hline Tradables & 2.7 & 1.0 & 0.4 & 0.2 \\
Manufcaturing & 4.5 & 1.1 & 1.1 & 0.5 \\
Mining & -0.6 & -0.6 & 0.4 & -0.6 \\
Agriculture & 2.9 & 3.0 & -2.4 & -0.5 \\
Non-tradables & 3.1 & 1.5 & 2.2 & 3.7 \\
\hline
\end{tabular}

Source: TIPS South Africa Standardised Industry Data Base and own calculations

How did the trends in the different variables differ between the tradable and the non-tradable sectors in the 1970s, when both sectors were growing at similar healthy rates? The exercise undertaken for the manufacturing sector and reported in Table 1, is now applied to the tradables and non-tradable sectors for the decade of the 1970s. We also report separately the results for the components of the tradable sector - mining, agriculture, and manufacturing.

Table 4: Decomposition of Real Wage Growth in the 1970s, Selected Sectors

\begin{tabular}{|c|c|c|c|c|c|c|c|c|c|}
\hline Period & $\hat{w}$ & $\hat{v}$ & $\hat{L}$ & $\hat{P_{p}}$ & $\begin{array}{l}\text { DRER= } \\
\hat{P_{p}}-\hat{P}_{c}\end{array}$ & $\alpha$ & $\begin{array}{l}\text { Output } \\
\text { Effect }\end{array}$ & $\begin{array}{c}\text { Wage share } \\
\text { effect }\end{array}$ & $\begin{array}{c}\text { Price } \\
\text { Effec } \\
(5)+(8\end{array}$ \\
\hline & 1 & 2 & 3 & 4 & 5 & 6 & 7 & 8 & 9 \\
\hline Tradables & 4.8 & 2.7 & 1.4 & 16.4 & 5.1 & 0.91 & 2.5 & -1.4 & 3.7 \\
\hline Mining & 10.8 & -0.6 & 2.1 & 28.1 & 16.7 & 0.88 & -0.5 & 3.4 & 12.4 \\
\hline Manufcaturing & 2.5 & 2.9 & -0.2 & 10.5 & -0.9 & 1.02 & 2.9 & 0.2 & -0.7 \\
\hline Agriculture & 2.6 & 4.5 & 2.4 & 12.1 & 0.8 & 0.88 & 4.4 & -0.3 & 0.5 \\
\hline Non-tradables & 0.2 & 3.1 & 2.4 & 11.5 & 0.1 & 0.95 & 3.0 & -0.5 & -0.4 \\
\hline
\end{tabular}

Source: TIPS South Africa Standardised Industry Data Base and own calculations

A major difference in the nature of the wage-employment trade-off is seen between the tradable and the non-tradable sectors. The latter behaved very much like the expectation in the traditional Lewis model - employment growing at a steady rate with a more or less constant real wage. It conforms to the picture of a surplus labour model with an elastic supply of labour to the modern (formal) sector. We have already seen, by contrast, that the manufacturing sector showed some evidence of sharing the gains of output growth equally between employment increases and wage increases. Furthermore, the results given Table 4 show a substantial difference between the tradable sector as a whole and the manufacturing component of it. The trade-off in the former seems to be heavily weighted in favour of wage growth. In fact, the rate of real wage increase is well above the rate of growth of output and this in spite of a modest rate of increase of employment. A glance at the table will show that this was possible only because the terms of trade moved in favour of the tradable sector, with the producer price increase running way ahead of the consumer price increase. The major player in this scenario seems to have been the mining sector where the product prices increased at a whopping $28 \%$ per annum. The windfall accruing to mining due to this price increase was shared out with the existing body of workers. For example, the 1972 wildcat strikes in Durban led mining houses to be more reactive to wage

demands. Also prior to this, African wages had been relatively constant in nominal terms for some 30 years, so that this was seen at the time as more of a 'catch-up' wage increase. Real earnings increased at a spectacular $11 \%$ rate and even a small rate of increase in employment was possible without eating into profit rates. The share of wages in value added actually fell, as in manufacturing. 
In sum: the experience of the 1970s suggest that, while the non-tradable sector behaved much like the predictions of the Lewis model with an unlimited supply of labour, the tradable sector was already showing the signs of sharing its output gains with those already in employment in the form of wage increases. The importance of efficiency wage and/or profit sharing is clearly relevant here, since presumably during this period, the influence of the institutional issues had not become that strong. Particular interest can be attached to the behaviour of the mining sector, where, as we saw the windfall gains due to the sharp increase in producer prices, were largely distributed to the workers in the form of large real wage increase.

While the behaviour of the non-tradable labour market was much closer to a competitive model, given the surplus labour conditions in the economy, what has been the experience since the 1970s when the South African formal sector experienced a much-reduced rate of growth?

Figure 1 and Figure 2 depict the decomposition results in the tradable and non-tradable sectors respectively for the three periods: the 1980s, the first half of the 1990s and the second half of the 1990s.

\section{Figure 2: Decomposition of Growth in the Real Wage Rate of 'tradables (agriculture, mining \& manufacturing)' (SIC: 1-3)}

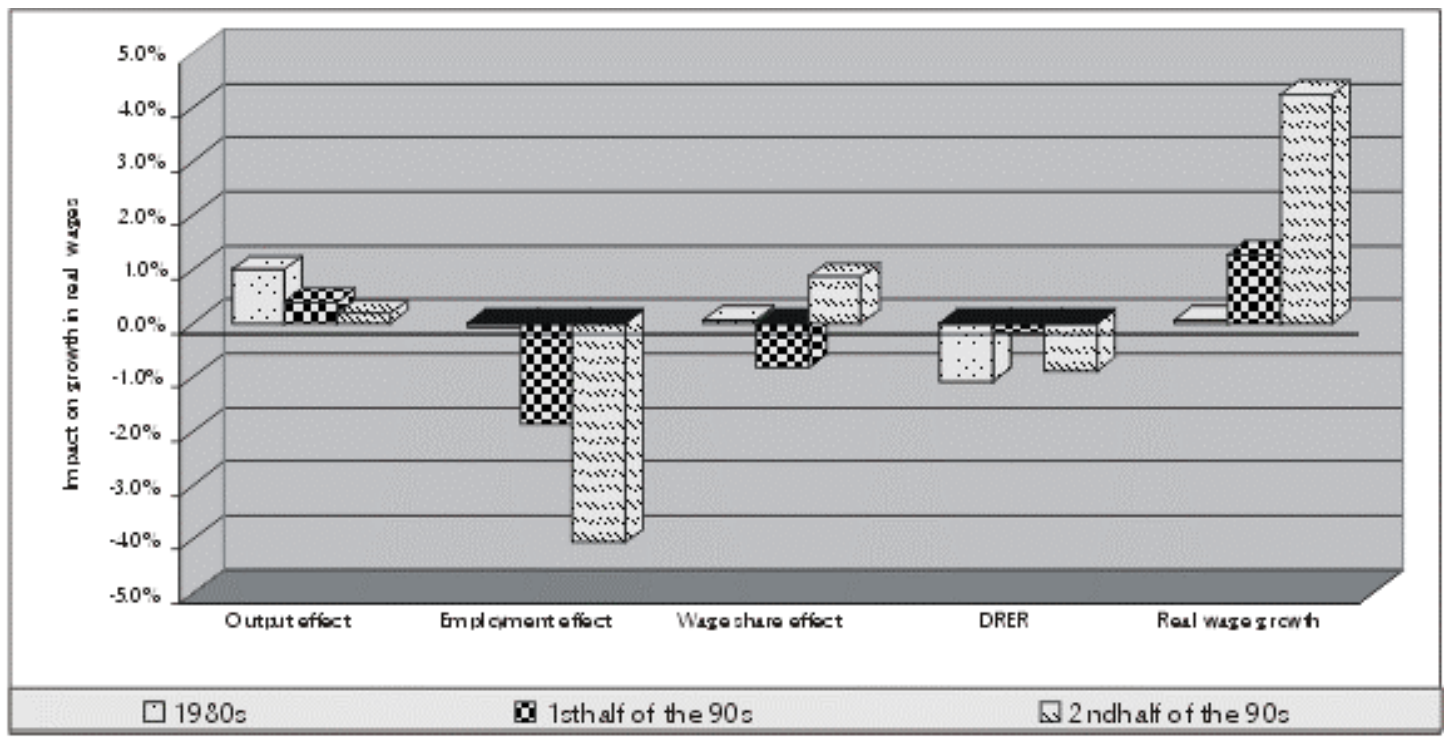

Source: TIPS South African Standardised Industry Data Base and own calculations

A glance at the two diagrams should be sufficient to convince the reader that the difference between the two sectors in the wage-employment determination, which existed in the 1970s, had disappeared. The nature of the 'trade-off' is remarkably similar for the two sectors. It shifted over the two decades towards real wage growth at the expense of employment; the shift becoming increasingly stronger through the 1990s. There is a quantitative difference between the sectors, in so far as the real output growth was higher throughout in the non-tradable sector and the difference in its favour increased over the period. The fact that the DRER also was positive for the non-tradables, but not for the tradables, meant that a larger part of the 'cake' was available for distribution between wage and employment growth in the non-tradables. Thus non-tradables were able to achieve a higher rate of real wage increase than the tradable with a smaller rate of employment decline. We conclude that the labour market outcome became much more uniform throughout the economy. It favoured wage growth rather than employment increase. The 
pervasiveness of this preference suggests that the forces influencing this particular labour market outcome have been very similar throughout the different sectors of the labour market.

\section{Figure 3: Decomposition of Growth in the Real Wage Rate of 'non-tradables (electricity, construction \& services)' (SIC: 4-9)}

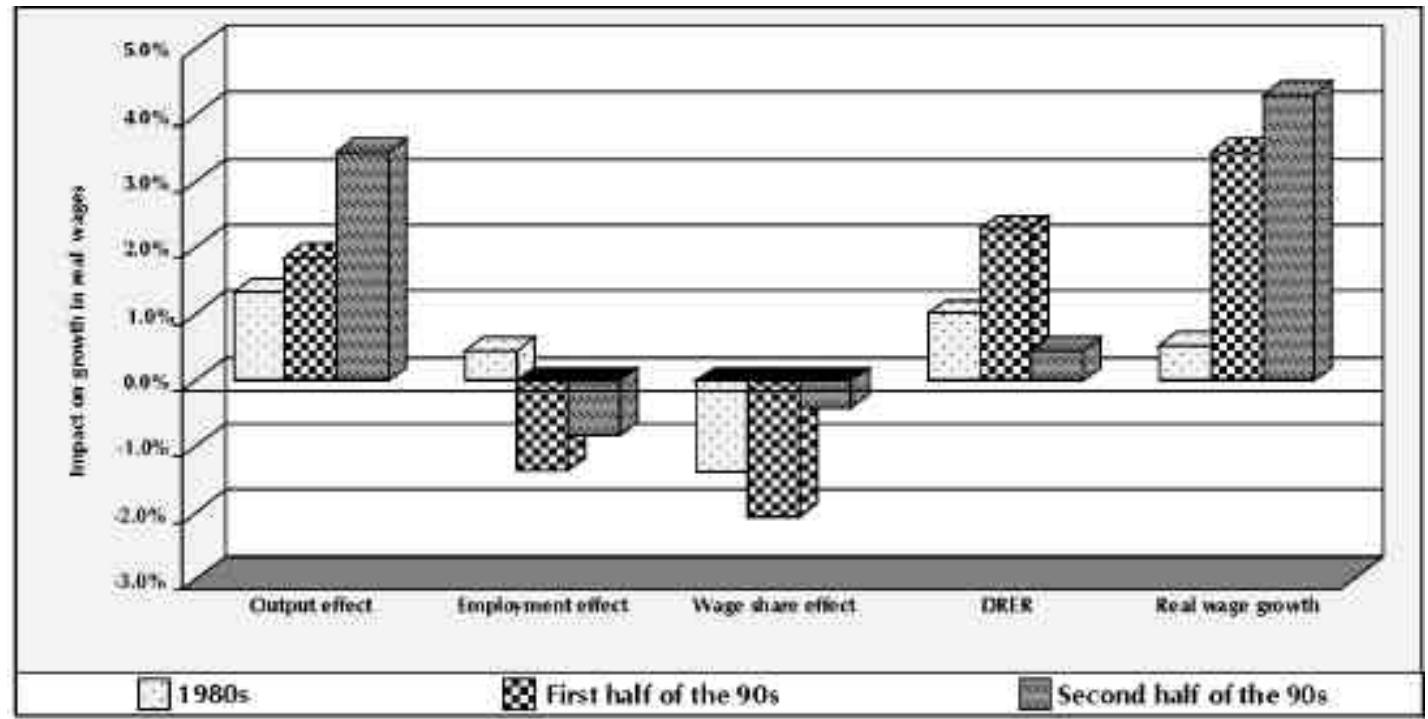

Source: TIPS South African Standardised Industry Data Base and own calculations

What happened to the mining sector, which, we have seen, had achieved a very high rate of real wage growth in the 1970s while still maintaining a low positive rate of employment growth? Figure 3 portrays the outcome over the three periods distinguished. The strong DRER effect, which had increased the size of the 'cake' to be shared between wage and employment increase, had disappeared after commodity market booms of the 1970s and early 1980s. In fact, the product prices were increasing at a lower rate than consumer prices in the 1980s and the first half of the 1990s, and increased only at a slightly higher rate in the second half of the 1990s. Given the very small rate of increase of real value added, the increasingly higher rate of real wage increase could only be maintained at the cost of an increasing higher rate of decline of employment. The experience of the mining sector, inclining strongly to wage increase in the second half of the 1990s, was no different to the rest of the tradables sector. 
Figure 4: Decomposition of Growth in the Real Wage Rate of 'all mining' (SIC: 2)

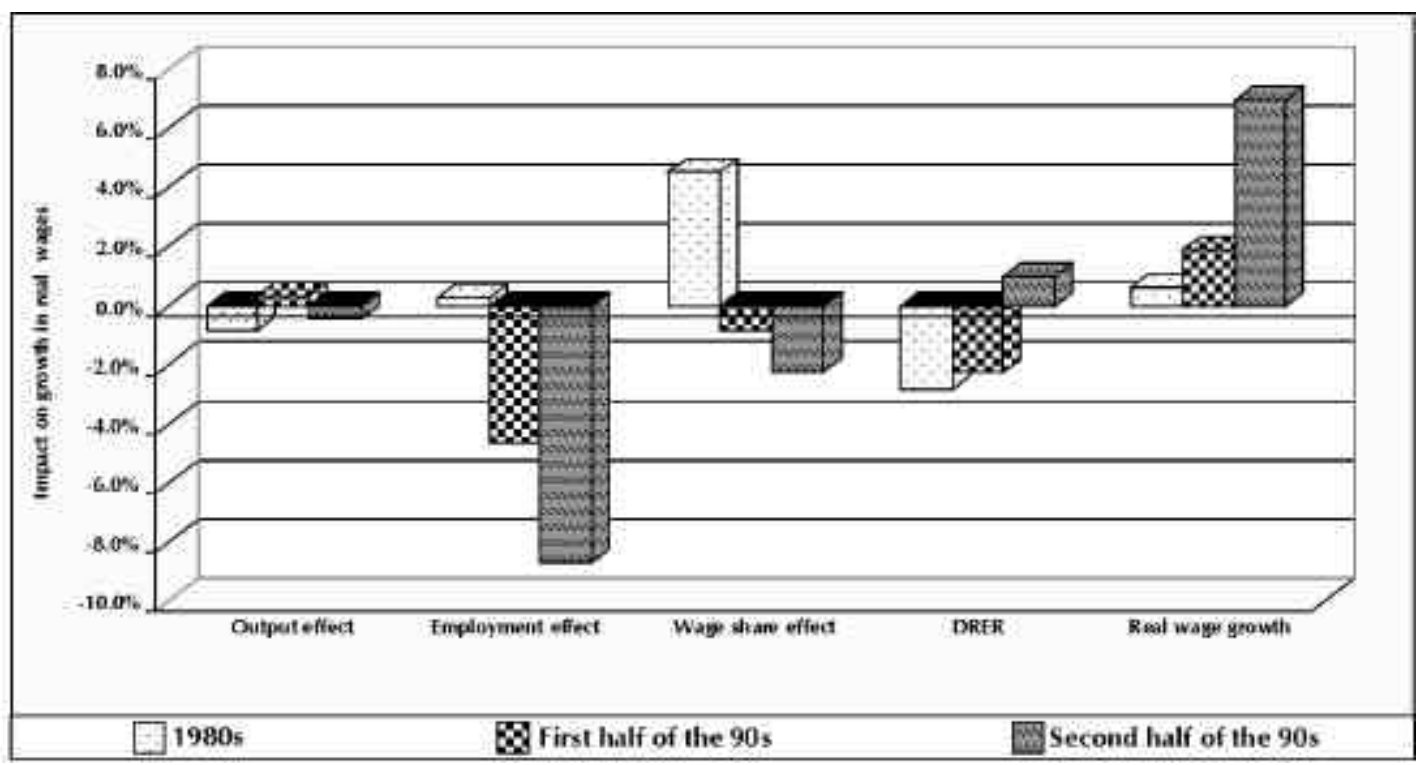

Source: TIPS South African Standardised Industry Data Base and own calculations

\section{Different Groups within the Manufacturing Sector}

Let us now look at the experience of the sub-groups within manufacturing. Manufacturing industries can be grouped into three classes. The manufacturing sub groups loosely follow the factor content of the means of production. Hence, we distinguish labour intensive industries (food, beverages, tobacco, textiles, clothing, leather, footwear, plastic products, glass products and furniture producers), capital intensive industries (wood, paper, chemicals, other non-metallic minerals and basic and fabricated metals producers) and technology rich industries (machinery, electrical machinery, electronics, professional and scientific and other industries as well as printing and recorded media producers).

Table 5: Growth rates (real value added) for manufacturing groups

\begin{tabular}{|l|c|c|c|c|}
\hline Group & $\mathbf{1 9 7 0 s}$ & $\mathbf{1 9 8 0 s}$ & $\mathbf{1 9 9 0 s}^{\text {st }}$ half & 1990s-2 $^{\text {nd }}$ half $^{\text {s. }}$ \\
\hline Light manufacturing & 5.3 & 1.6 & 0.5 & -0.5 \\
\hline $\begin{array}{l}\text { Heavy } \\
\text { manufacturing }\end{array}$ & 4.0 & 1.6 & 1.9 & 0.0 \\
\hline $\begin{array}{l}\text { High tech } \\
\text { manufacturing }\end{array}$ & 4.5 & 0.1 & 0.5 & 2.2 \\
\hline
\end{tabular}

Source: TIPS South African Standardised Industry Data Base and own calculations

In Table 5 it can be seen that in the 1970s the light-manufacturing sub-group, which benefited most from the inward industrialisation policies of the day, was leading in terms of real growth rate, but then it gradually fell off ending up with a negative growth rate in the second half of the 1990s, as it started to feel the pinch of South Africa's trade liberalisation measures. The heavy industries held up a respectable positive rate of growth in the 1980s and the first half of the 1990s, although at a much more reduced rate than in the 1970s, but were stagnant in the latter 
half of the 1990s. The technology group is the only one which has been increasing its growth rate in the 1990s although it had also shared in the general reduction of growth in the 1980s. In

the second half of the $1990 \mathrm{~s}$ it increased its rate of growth to $2.2 \%$ which was four times the average growth for manufacturing as a whole.

Are the trends in the different variables in the decomposition exercise different for these subgroups than what was noticed for all manufacturing above? First, Table 6 presents the values of the relevant variables for the decade of the 1970s. It will be recalled that the major conclusion with respect to total manufacturing was, that the fruits of output growth were shared almost equally between wage growth and employment growth.

Table 6: Decomposition Exercise for Sub-groups in Manufacturing, 1970s (\% growth per year)

\begin{tabular}{|l|c|c|c|c|c|c|c|c|c|}
\hline Sub-group & $\hat{w}$ & $\hat{v}$ & $\hat{L}$ & $\hat{P_{p}}$ & $\begin{array}{c}\text { DRER= } \\
\hat{P_{p}}-\hat{P_{c}}\end{array}$ & $\hat{\alpha}$ & $\begin{array}{c}\text { Output } \\
\text { Effect }\end{array}$ & $\begin{array}{c}\text { Wage } \\
\text { share } \\
\text { effect }\end{array}$ & $\begin{array}{c}\text { Price } \\
\text { Effect } \\
(5)+(8)\end{array}$ \\
\hline & 1 & 2 & 3 & 4 & 5 & 6 & 7 & 8 & 9 \\
\hline $\begin{array}{l}\text { Light } \\
\text { manufacturing }\end{array}$ & 2.0 & 5.3 & 2.4 & 10.5 & -0.9 & 1.0 & 5.3 & -0.1 & -0.9 \\
\hline $\begin{array}{l}\text { Heavy } \\
\text { manufacturing }\end{array}$ & 3.7 & 4.0 & 2.4 & 14.1 & 2.8 & 0.99 & 3.7 & -0.5 & 2.3 \\
\hline $\begin{array}{l}\text { High tech } \\
\text { manufacturing }\end{array}$ & 1.8 & 4.5 & 2.4 & 11.3 & -0.1 & 0.95 & 4.3 & -0.1 & -0.2 \\
\hline $\begin{array}{l}\text { Total } \\
\text { manufacturing }\end{array}$ & 2.6 & 4.5 & 2.4 & 12.1 & 0.8 & 0.88 & 4.4 & -0.3 & 0.5 \\
\hline
\end{tabular}

Source: TIPS South African Standardised Industry Data Base and own calculations

The figures show that heavy manufacturing stands out from the others. Its rate of output growth was the lowest of the sub-groups, but the DRER effect increased the rate of increase of the real wage bill to a higher level than the other groups, because its product prices had a rate of increase significantly higher than the consumer price increase. With this larger rate of growth of the 'cake' this sub-sector tilted the distribution in favour of real wage growth rather than employment growth. Thus, while the rate of employment growth increased at the same rate in all sectors (truly by coincidence), heavy industry had a higher rate of real wage increase. Apart from this difference in the price effect, the general pattern of the 1970s of sharing output growth equally between wage and employment growth is valid for al three sub-sectors as for manufacturing as a whole. 
Figure 5: Decomposition of Growth in the Real Wage Rate of 'labour intensive manufacturing' (SIC: 301-302, 391)

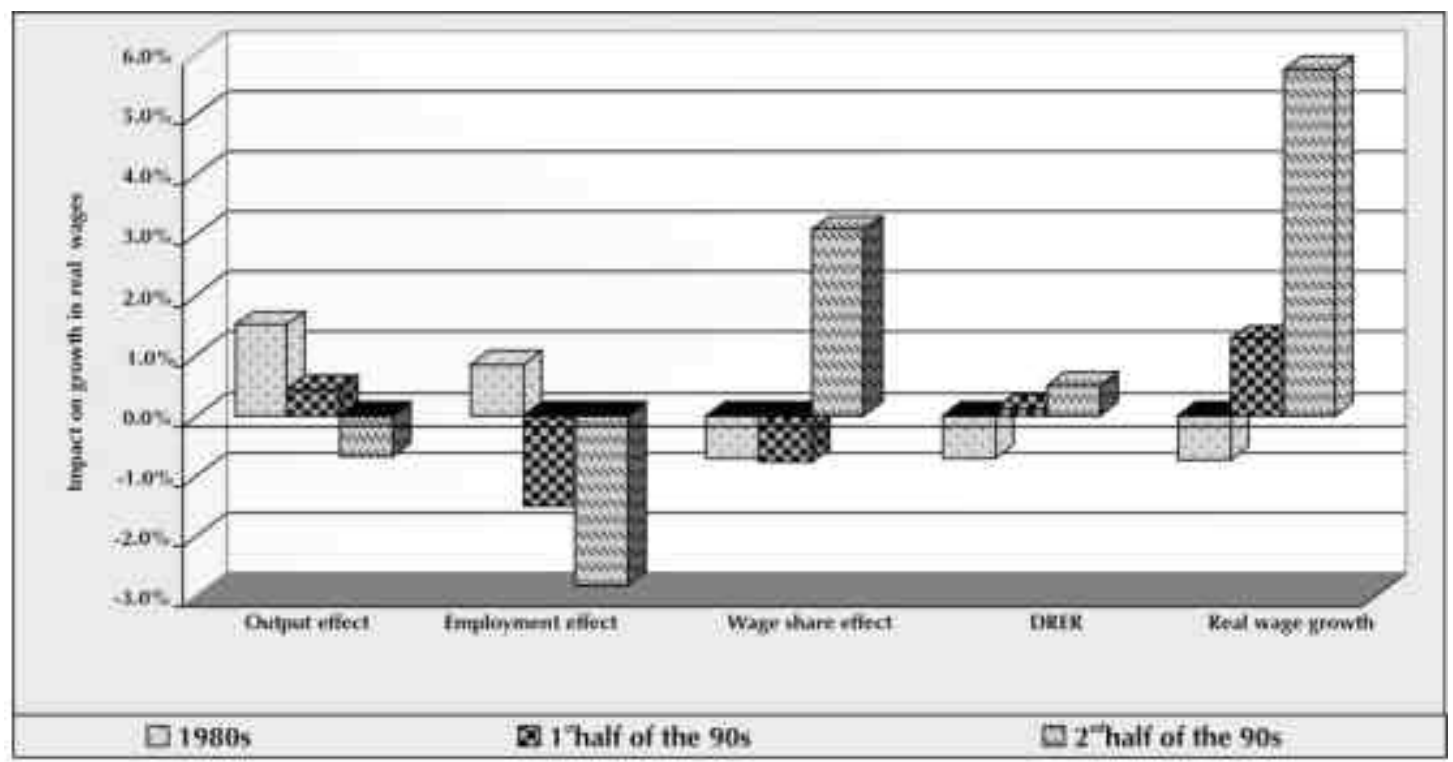

Source: TIPS South African Standardised Industry Data Base and own calculations

Against this background, we now turn to the picture as it unfolded in the 1980s and the 1990s. The development is portrayed in Figure 5, Figure 6, and Figure 7.

Figure 6: Decomposition of Growth in the Real Wage Rate of 'capital intensive' manufacturing' (SIC: 323, 331-355)

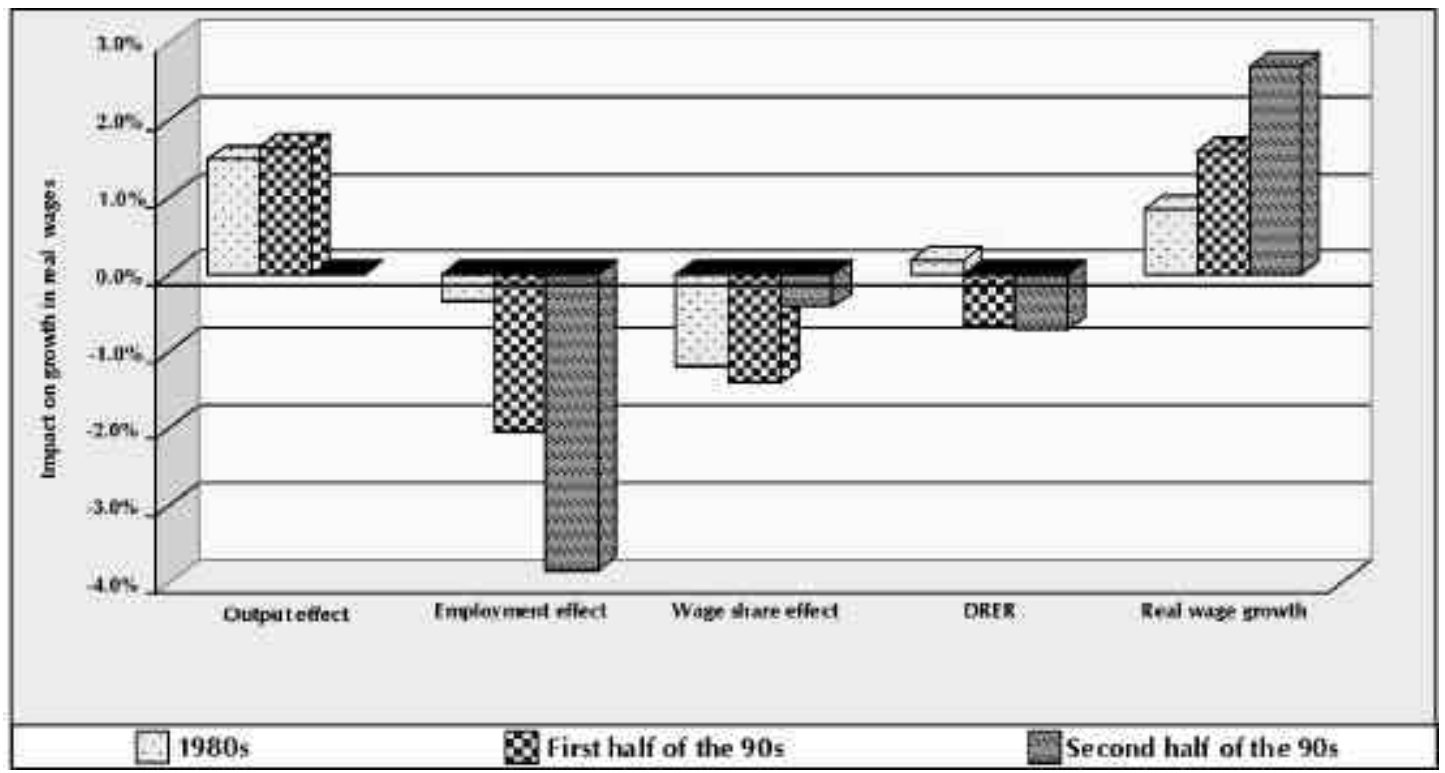

Source: TIPS South African Standardised Industry Data Base and own calculations 
The picture and its evolution in the three periods shown, is very much the same for total manufacturing apart from minor quantitative differences. As the time period rolled on, the distribution of the fruits of output growth was increasingly slanted in favour of wage growth rather than employment increase. This bias resulted in a pronounced decrease in employment in the first half of the 1990s and more so in the second half. All three sub-sectors had similar experience. The high tech sub-sector was the only one that managed to have an increasing rate of output over the period. This was partly offset by an adverse movement of the DRER with product prices falling relative to consumer prices. Nevertheless, the output growth enabled this sub-group to have a rate of employment decline in the second half of the 1990s that was the lowest of the three sub-sectors, in spite of a rate of real wage increase as high as or even higher than the other sub-groups.

Figure 7: Decomposition of Growth in the Real Wage Rate of 'high tech manufacturing' (SIC: 324-326, 356-387, 392)

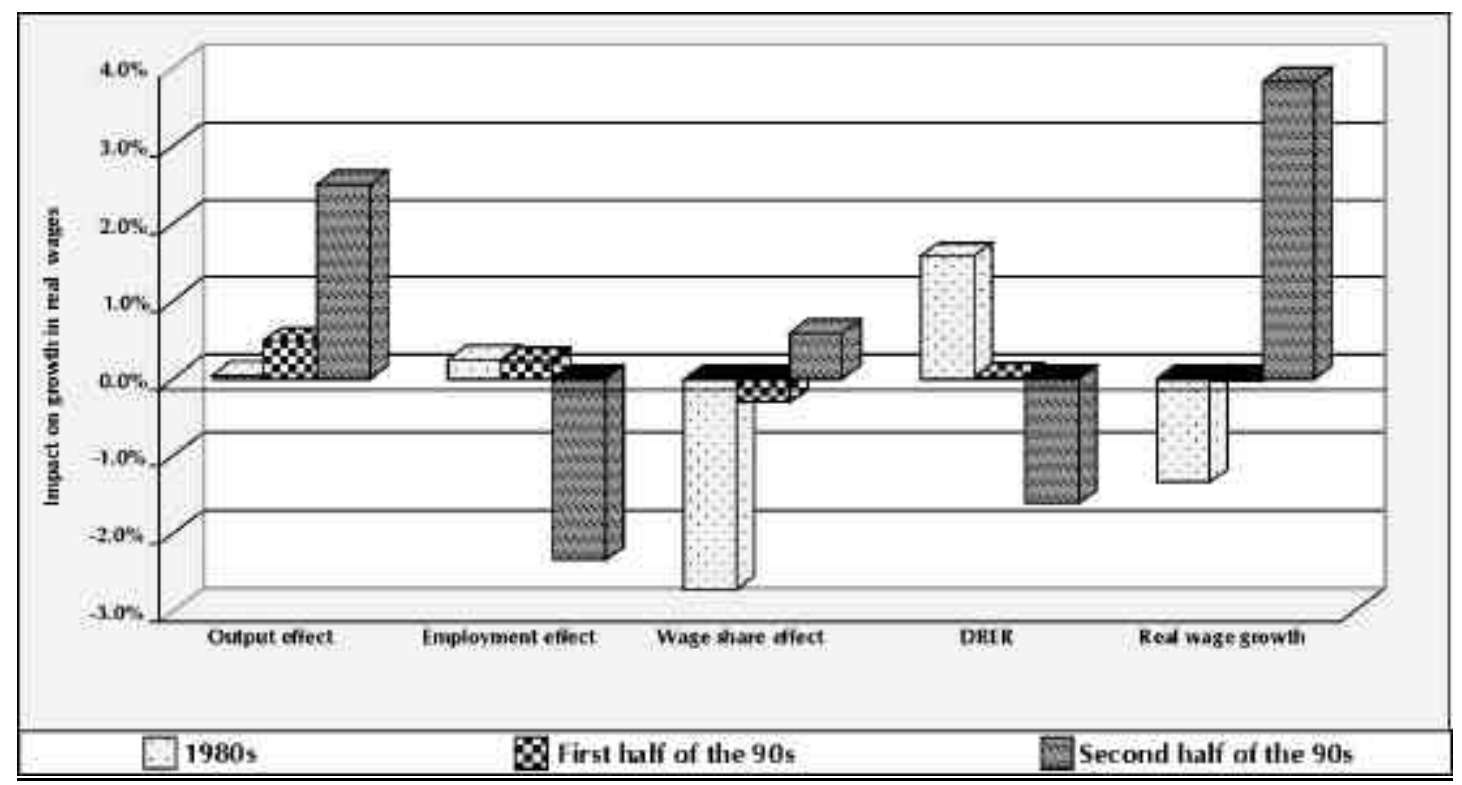

Source: TIPS South African Standardised Industry Data Base and own calculations 


\section{Conclusions}

In the 1970s the process of wage determination differed significantly between the tradable and the non-tradable sub-sectors of South Africa's formal economy. An elastic supply of labour appeared to prevail in the non-tradable sector, consistent with surplus labour conditions in the economy. Thus, in spite of the respectable rate of growth in the sub-sector, real wages remained more or less stagnant, and all of the increase in output and wage bill was taken in the form of employment increase. By contrast, the manufacturing component of the tradable sector divided the increase in output almost equally between real wage growth and employment increase. Other sub-sectors within the tradable group, particularly mining, had a bonanza in the form of a huge increase in its relative product prices. Consistent with the prevalence of profit sharing forces, the impact of this 'price-effect' was to cause real wage increase of a substantial amount even while real output growth was stagnant, and employment increased only at a slow rate.

The trade-off between wage growth and employment growth began to shift towards wage growth in all sectors in the 1980s and became strongly biased towards wage growth as the 1990s progressed, even as the rate of growth of real output declined sharply. The difference between the tradable and the non-tradable sectors also disappeared. Different industry groups within manufacturing also showed roughly similar patterns of bias towards wage increase - which became very obvious in the second half of the 1990s.

The pervasiveness of the bias towards wage increase in the division of the fruits of output growth between wage and employment increase, suggests that the underlying forces causing this type of development in the labour market are economy-wide, at least as far as the formal sector is concerned. Some suggestions about possible causes - both economic and institutional - have been made above. The choice between these possible hypotheses or an evaluation of the relative strength of each, require more detailed research.

The outcomes in the manufacturing labour market for formal manufacturing in South Africa can be compared with results found for other regions of the world (for the 1970s and the 1980s) in earlier work by Mazumdar (2001). In the 1970s South Africa followed the East Asian model of roughly equal division of the fruits of output growth between wage and employment increase. But then the pattern shifted, gradually through the 1980s and into the 1990s, towards the European model which favoured real wage growth even at the cost of employment decline. The experience contrasts strongly with the experience of the rest of Sub-Saharan Africa where the bias has been consistently towards employment growth, even at the cost of a significant declining trend in real wages. Another important distinction between South Africa and the other regions of the world is the very limited role of the 'price-effect' on the 'real cake' to be shared between wage and employment increase. This is partly because of inflation rates being substantially lower than in several other regions, notably Latin America. Another reason is that unlike several other regions the DRER effect has mostly been minimal, since product prices have tended to increase close to the rate of increase of consumer prices. 
It must be realised that we have applied our decomposition analysis at the sectoral level as well as for a select number of clusters of sectors such as tradables and non-tradables. Although one could consider clustering at different levels it may seem useful to consider a size class clustering around small, medium and large firms. Moreover, with appropriate data it makes sense to investigate a decomposition of real wage growth by population group or skill level [using survey data to assist you here? The latter may be far fetched given data constraints but could still be considered if only a few data points were available.

\section{References}

Gibson, B. 2000: Will lower wages cause faster growth in South Africa, Journal for Studies in Economics and Econometrics, vol 24, no 3: 143-163.

Lewis, JD. 2001: Policies to promote growth and employment in South Africa, TIPS Annual Forum

Mazumdar, D. 2000: Trends in employment and the employment elasticity in manufacturing 197192: an international comparison, TIPS 2000 Annual Forum.

Mazumdar, D. 2001: Trends in Employment and the Employment Elasticity in Manufacturing 1971-92: An International Comparison, Cambridge Journal of Economics, forthcoming.

Mazumdar, D (with Ata Mazaheri) 2002: Wages and Employment in Africa, Asgate Academic Publishers, Aldershot, UK, forthcoming. 


\section{Appendix A: Detailed Industry Results}

In this appendix we show detailed results for a fair number of industries (following the classification of TIPS' South Africa Standardised Industry Data Base) and aggregates thereof in the South African economy, based on time series data for the period 1970 and 2000 available at TIPS. As in the main text, we make a simple distinction between tradable and non-tradable industries, with the former covering the primary and manufacturing sectors, while the latter includes electricity, construction and the services. With regard to services this may not be entirely correct these days as a number of services can now be considered as tradable. The manufacturing sub groups loosely follow the factor content of the means of production. Hence, we distinguish labour intensive industries (food, beverages, tobacco, textiles, clothing, leather, footwear, plastic products, glass products and furniture producers), capital intensive industries (wood, paper, chemicals, other non-metallic minerals and basic and fabricated metals producers) and technology rich industries (machinery, electrical machinery, electronics, professional and scientific and other industries as well as printing and recorded media producers). For reasons of display, we present weighted average annual growth rates for the 1970s, 1980s the first half of the 1990s, the second half of the 1990s, the 1990s and the whole period. The ingredients to the application of equation 7 are shown in the next four tables 
Table A 1: Growth in Nominal Value Added

\begin{tabular}{|c|c|c|c|c|c|c|c|c|c|c|c|c|c|}
\hline & & & & & & & $\hat{V}$ & & & & & & \\
\hline$\overline{\mathrm{Nr}}$ & Description & $\overline{\mathrm{SIC}}$ & $\begin{array}{c}1970 \mathrm{~s} \\
1\end{array}$ & $\begin{array}{c}\text { rank } \\
2\end{array}$ & $\begin{array}{c}1980 \mathrm{~s} \\
3\end{array}$ & $\begin{array}{c}\text { rank } \\
4\end{array}$ & $\begin{array}{c}1^{\text {sh half } 90 \mathrm{~s}} \\
5\end{array}$ & $\begin{array}{c}\text { rank } \\
6\end{array}$ & $\begin{array}{c}2^{\text {nd }} \text { half } 90 \mathrm{~s} \\
7\end{array}$ & 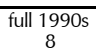 & $\begin{array}{c}\text { rank } \\
9\end{array}$ & $\begin{array}{c}\text { full period } \\
10\end{array}$ & $\begin{array}{c}\text { rank } \\
11\end{array}$ \\
\hline 1. & Plastic products & 338 & $24.5 \%$ & 4 & $18.3 \%$ & 15 & $10.6 \%$ & 35 & $18.8 \%$ & $13.9 \%$ & 9 & $18.8 \%$ & 4 \\
\hline 2. & Communication & 75 & $12.6 \%$ & 39 & $24.5 \%$ & 1 & $19.1 \%$ & 3 & $18.8 \%$ & $20.8 \%$ & 1 & $19.7 \%$ & 1 \\
\hline 3. & Water supply & 42 & $16.7 \%$ & 20 & $11.0 \%$ & 42 & $11.9 \%$ & 24 & $18.1 \%$ & $14.9 \%$ & 4 & $13.3 \%$ & 38 \\
\hline 4. & Other mining & $22 / 24 / 25 / 29$ & $27.1 \%$ & 2 & $17.8 \%$ & 17 & $15.0 \%$ & 7 & $17.7 \%$ & $14.0 \%$ & 8 & $15.2 \%$ & 23 \\
\hline 5. & Finance \& insurance & $81-82$ & $17.2 \%$ & 13 & $24.2 \%$ & 2 & $14.2 \%$ & 11 & $15.7 \%$ & $14.6 \%$ & 6 & $18.6 \%$ & 5 \\
\hline$\overline{6 .}$ & Business services & $83-88$ & $11.3 \%$ & 42 & $13.5 \%$ & 34 & $16.8 \%$ & 4 & $13.6 \%$ & $15.5 \%$ & 3 & $16.1 \%$ & 19 \\
\hline 7. & Other producers & 98 & $12.8 \%$ & 38 & $15.8 \%$ & 25 & $14.7 \%$ & 8 & $12.8 \%$ & $14.6 \%$ & 7 & $15.1 \%$ & 25 \\
\hline 8. & Other chemicals & $335-336$ & $20.8 \%$ & 8 & $20.5 \%$ & 9 & $11.7 \%$ & 25 & $12.6 \%$ & $12.9 \%$ & 11 & $19.1 \%$ & 3 \\
\hline 9. & Soc serv: medical & 93 & $14.5 \%$ & 30 & $19.8 \%$ & 11 & $26.7 \%$ & 1 & $12.4 \%$ & $18.5 \%$ & 2 & $19.7 \%$ & 2 \\
\hline 10. & TV \& comms equipm & $371-373$ & $19.0 \%$ & 10 & $17.2 \%$ & 19 & $9.4 \%$ & 38 & $11.0 \%$ & $8.2 \%$ & 30 & $16.4 \%$ & 18 \\
\hline 11. & Print, publ \& rec media & 324326 & $13.5 \%$ & 35 & $15.3 \%$ & 27 & $13.4 \%$ & 16 & $10.6 \%$ & $10.5 \%$ & 17 & $15.2 \%$ & 24 \\
\hline 12. & Wood and products & $321-322$ & $13.6 \%$ & 34 & $16.4 \%$ & 20 & $13.7 \%$ & 13 & $10.4 \%$ & $11.6 \%$ & 14 & $15.2 \%$ & 22 \\
\hline 13. & Mot veh \& access & $381-383$ & $14.7 \%$ & 26 & $21.4 \%$ & 7 & $10.8 \%$ & 33 & $9.9 \%$ & $9.4 \%$ & 23 & $16.8 \%$ & 14 \\
\hline 14. & Soc serv: other & 9496 & $14.5 \%$ & 28 & $15.9 \%$ & 24 & $22.5 \%$ & 2 & $9.6 \%$ & $14.8 \%$ & 5 & $16.4 \%$ & 17 \\
\hline 15. & Basic chemicals & 334 & $16.8 \%$ & 18 & $22.0 \%$ & 5 & $8.2 \%$ & 40 & $9.4 \%$ & $10.6 \%$ & 16 & $17.8 \%$ & 8 \\
\hline$\overline{16 .}$ & Tobacco & 306 & $11.2 \%$ & 43 & $12.8 \%$ & 39 & $15.7 \%$ & 6 & $8.7 \%$ & $13.9 \%$ & 10 & $13.7 \%$ & 34 \\
\hline 17. & Rubber products & 337 & $16.8 \%$ & 19 & $13.4 \%$ & 35 & $11.3 \%$ & 27 & $8.4 \%$ & $7.6 \%$ & 33 & $13.4 \%$ & 37 \\
\hline 18. & Wearing apparel & $313-315$ & $12.6 \%$ & 40 & $14.8 \%$ & 31 & $12.8 \%$ & 19 & $7.8 \%$ & $9.1 \%$ & 25 & $14.0 \%$ & 32 \\
\hline 19. & Transport & $71-74$ & $17.2 \%$ & 16 & $14.8 \%$ & 32 & $12.3 \%$ & 21 & $7.5 \%$ & $10.2 \%$ & 20 & $14.7 \%$ & 30 \\
\hline 20. & Beverages & 305 & $15.9 \%$ & 23 & $19.2 \%$ & 13 & $14.6 \%$ & 9 & $7.5 \%$ & $12.4 \%$ & 12 & $17.0 \%$ & 12 \\
\hline 21. & Furniture & 391 & $13.2 \%$ & 37 & $13.9 \%$ & 33 & $12.3 \%$ & 20 & $7.1 \%$ & $6.8 \%$ & 37 & $14.2 \%$ & 31 \\
\hline 22. & Trade & $61-63$ & $14.3 \%$ & 32 & $17.3 \%$ & 18 & $13.9 \%$ & 12 & $6.7 \%$ & $10.2 \%$ & 19 & $16.0 \%$ & 20 \\
\hline 23. & Civil eng & $52-53$ & $17.2 \%$ & 15 & $11.3 \%$ & 40 & $13.5 \%$ & 15 & $6.5 \%$ & $10.9 \%$ & 15 & $13.6 \%$ & 36 \\
\hline 24. & Leather and products & 316 & $14.5 \%$ & 29 & $18.4 \%$ & 14 & $11.0 \%$ & 30 & $6.5 \%$ & $4.5 \%$ & 40 & $13.9 \%$ & 33 \\
\hline 25. & Glass and products & 341 & $16.0 \%$ & 22 & $18.2 \%$ & 16 & $13.1 \%$ & 17 & $6.2 \%$ & $9.0 \%$ & 26 & $16.9 \%$ & 13 \\
\hline$\overline{26 .}$ & Electrical mach & $361-366$ & $17.7 \%$ & 12 & $13.1 \%$ & 38 & $11.1 \%$ & 29 & $6.1 \%$ & $7.9 \%$ & 32 & $14.8 \%$ & 27 \\
\hline 27. & Other manufact & $392-393$ & $14.4 \%$ & 31 & $22.0 \%$ & 6 & $12.1 \%$ & 23 & $5.5 \%$ & $8.6 \%$ & 27 & $16.6 \%$ & 16 \\
\hline 28. & Machinery & $356-359$ & $16.2 \%$ & 21 & $10.8 \%$ & 43 & $8.5 \%$ & 39 & $5.1 \%$ & $8.4 \%$ & 29 & $12.9 \%$ & 40 \\
\hline 29. & Construction & 51 & $8.2 \%$ & 45 & $14.9 \%$ & 30 & $12.2 \%$ & 22 & $5.0 \%$ & $9.5 \%$ & 22 & $13.6 \%$ & 35 \\
\hline 30. & Cat \& accomm serv & 64 & $9.4 \%$ & 44 & $23.3 \%$ & 4 & $13.7 \%$ & 14 & $4.7 \%$ & $10.3 \%$ & 18 & $17.6 \%$ & 10 \\
\hline 31. & Coal mining & 21 & $36.5 \%$ & 1 & $13.2 \%$ & 36 & $11.5 \%$ & 26 & $4.5 \%$ & $10.1 \%$ & 21 & $16.7 \%$ & 15 \\
\hline 32. & Food & $301-304$ & $16.9 \%$ & 17 & $15.4 \%$ & 26 & $10.3 \%$ & 37 & $4.5 \%$ & $7.2 \%$ & 35 & $14.8 \%$ & 28 \\
\hline 33. & Paper and products & 323 & $15.8 \%$ & 24 & $23.3 \%$ & 3 & $14.5 \%$ & 10 & $4.4 \%$ & $9.2 \%$ & 24 & $17.8 \%$ & 9 \\
\hline 34. & Petroleum products & $331-333$ & $21.4 \%$ & 6 & $16.1 \%$ & 22 & $7.9 \%$ & 41 & $3.5 \%$ & $5.9 \%$ & 39 & $18.3 \%$ & 6 \\
\hline 35. & Electricity & 41 & $24.3 \%$ & 5 & $21.3 \%$ & 8 & $10.9 \%$ & 31 & $3.5 \%$ & $7.0 \%$ & 36 & $17.5 \%$ & 11 \\
\hline 36. & Basic nonferr met & 352 & $19.4 \%$ & 9 & $19.5 \%$ & 12 & $16.0 \%$ & 5 & $3.3 \%$ & $12.3 \%$ & 13 & $17.8 \%$ & 7 \\
\hline 37. & Basic iron \& steel & 351 & $21.3 \%$ & 7 & $16.1 \%$ & 21 & $10.3 \%$ & 36 & $2.9 \%$ & $8.2 \%$ & 31 & $15.1 \%$ & 26 \\
\hline 38. & Metal products & $353-355$ & $17.2 \%$ & 14 & $10.4 \%$ & 44 & $10.8 \%$ & 32 & $2.2 \%$ & $8.5 \%$ & 28 & $12.9 \%$ & 39 \\
\hline 39. & Agriculture & 1 & $13.3 \%$ & 36 & $15.1 \%$ & 29 & $11.2 \%$ & 28 & $0.8 \%$ & $7.5 \%$ & 34 & $12.3 \%$ & 41 \\
\hline 40. & Non-met min & 342 & $14.1 \%$ & 33 & $16.0 \%$ & 23 & $13.1 \%$ & 18 & $0.5 \%$ & $6.7 \%$ & 38 & $14.7 \%$ & 29 \\
\hline 41. & Textiles & $311-312$ & $14.6 \%$ & 27 & $13.2 \%$ & 37 & $3.6 \%$ & 43 & $-1.2 \%$ & $2.9 \%$ & 41 & $11.1 \%$ & 43 \\
\hline 42. & Prof \& sci equipm & 374376 & $12.5 \%$ & 41 & $20.3 \%$ & 10 & $10.6 \%$ & 34 & $-3.9 \%$ & $2.7 \%$ & 42 & $15.4 \%$ & 21 \\
\hline 43. & Gold & 23 & $26.3 \%$ & 3 & $8.7 \%$ & 45 & $2.2 \%$ & 44 & $-4.6 \%$ & $1.0 \%$ & 43 & $10.7 \%$ & 44 \\
\hline 44. & Other trnsp equipm & 384387 & $18.3 \%$ & 11 & $11.2 \%$ & 41 & $1.5 \%$ & 45 & $-7.0 \%$ & $-1.0 \%$ & 44 & $10.0 \%$ & 45 \\
\hline 45. & Footwear & 317 & $15.6 \%$ & 25 & $15.2 \%$ & 28 & $4.4 \%$ & 42 & $-11.3 \%$ & $-3.8 \%$ & 45 & $11.8 \%$ & 42 \\
\hline 46. & Total val add at fct cst & $1-9$ & $16.8 \%$ & & $16.0 \%$ & & $12.8 \%$ & & $8.7 \%$ & $11.1 \%$ & & $15.4 \%$ & \\
\hline 47. & Tradables & $1-3$ & $19.2 \%$ & & $14.7 \%$ & & $10.4 \%$ & & $5.7 \%$ & $8.5 \%$ & & $14.2 \%$ & \\
\hline 48. & Non-trade & 49 & $14.6 \%$ & & $17.3 \%$ & & $14.6 \%$ & & $10.5 \%$ & $12.7 \%$ & & $16.2 \%$ & \\
\hline 49. & Mining & 2 & $27.5 \%$ & & $11.4 \%$ & & $8.2 \%$ & & $6.7 \%$ & $7.8 \%$ & & $13.1 \%$ & \\
\hline 50. & Manufact & 3 & $16.6 \%$ & & $16.3 \%$ & & $11.0 \%$ & & $6.3 \%$ & $8.9 \%$ & & $15.3 \%$ & \\
\hline 51. & Light manf & $301-302,391$ & $15.8 \%$ & & $15.7 \%$ & & $10.7 \%$ & & $6.4 \%$ & $8.5 \%$ & & $14.7 \%$ & \\
\hline 52. & $\begin{array}{l}\text { Heavy manf } \\
\text { Tech manf }\end{array}$ & $\begin{array}{l}323,331-355 \\
324326,356-387,392\end{array}$ & $\begin{array}{l}18.1 \% \\
15.7 \%\end{array}$ & & $\begin{array}{l}16.6 \% \\
16.5 \%\end{array}$ & & $\begin{array}{l}11.4 \% \\
106 \%\end{array}$ & & $\begin{array}{l}5.7 \% \\
7.0 \%\end{array}$ & $\begin{array}{l}9.5 \% \\
8.5 \%\end{array}$ & & $\begin{array}{l}16.0 \% \\
15.1 \%\end{array}$ & \\
\hline
\end{tabular}

Source: TIPS South African Standardised Industrial Data Base and own calculations 
At the top of the ranking we find the plastics products industries with the highest nominal value added growth rates during the second half of the 1990s, followed by the communication services, the water supply sector (which includes distribution) and a few other tertiary sectors. The other chemicals (row 8), TV \& communication equipment (row 10) and motor vehicle producers (row 14) are the only downstream manufacturers in the top 10. All of the sectors mentioned here are on an upward trend in their ranking compared to the first half of the 1990s. At the bottom end of the table, we find sectors such as footwear (row 45, other transport equipment (row 44), gold (row 43), professional and scientific equipment (row 42), textiles (row 41), agriculture (row 39) and the metals cluster containing metal products (row 38), non ferrous metals (row 37) and basic iron \& steel (row 36) machinery and other transport equipment. Sectors that have lost considerable ground compared to the first half of the 1900s are trade (from rank 12, see row 22), catering and accommodation services (from rank 14, see row 30), paper (from rank 10, see row 33 ), non-ferrous metals (from rank 5, see row 37) and agriculture (from rank 28, see row 39). The next table presents growth rates of the same variable, but now in constant (1990) prices. 
Table A 2: Growth in Real Value Added

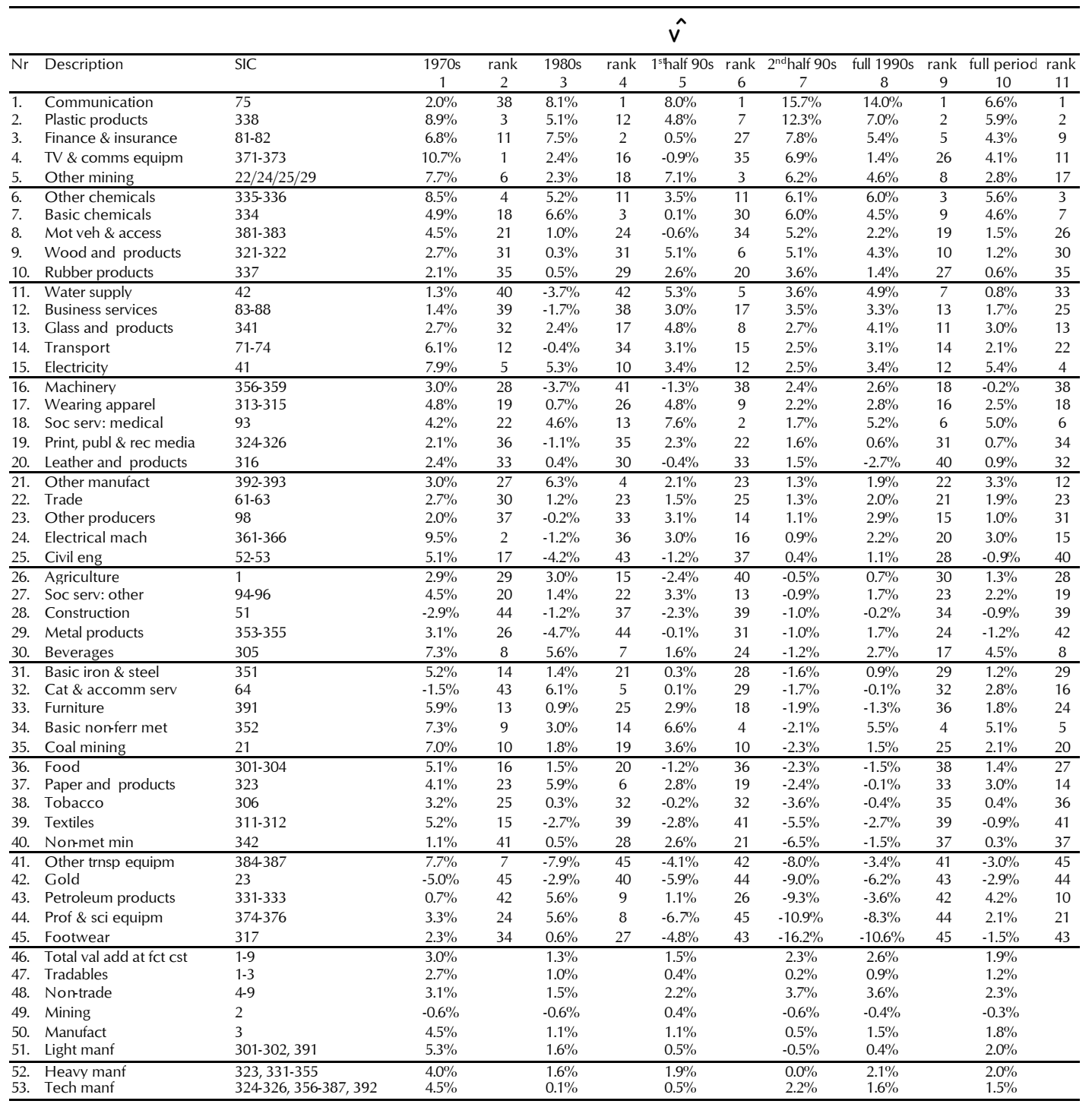

Source: TIPS South African Standardised Industrial Data Base and own calculations 
In row 46 it can be seen that total sectoral value added (excluding government and domestic household services) has grown on average by $2.3 \%$ during the second half of the 1990 s, which compares to $1.5 \%$ during the first half. Comparing Table A 1 and Table A 2 that at the top of the table, the ranking hasn't changed much. Newcomers are sectors such as basic chemicals (row 7), wood and products (row 9) and rubber products (row 10). At the bottom of the table a similar picture appears. It is also worth noting that tradables (defined here as the sum of agriculture, mining, manufacturing - see row 47) have consistently recorded lower real growth rates compared to non-tradables (electricity, construction and services - see row 48). Some services can also be considered as tradables such as communication, financial and business services and they score relatively high as can be seen in rows 1,3 and 12 respectively. In terms of manufacturing it is the technology producing industries (see row 53) that score higher than heavy industries (row 52) and light industries (row 51) throughout the 1990s, but in particular during the second half. Heavy industry is probably suffering from global saturation with commodities having been under pressure for some time, while light industry including food, textiles, clothing, footwear and furniture have started to feel the pinch from the trade liberalisation efforts in South Africa.

Although the real and nominal picture is broadly the same, the change in producer prices which is defined as the difference between the two growth rates, should show some sectoral variation as can be seen in the next table. 
Table A 3: Change in Producer Prices

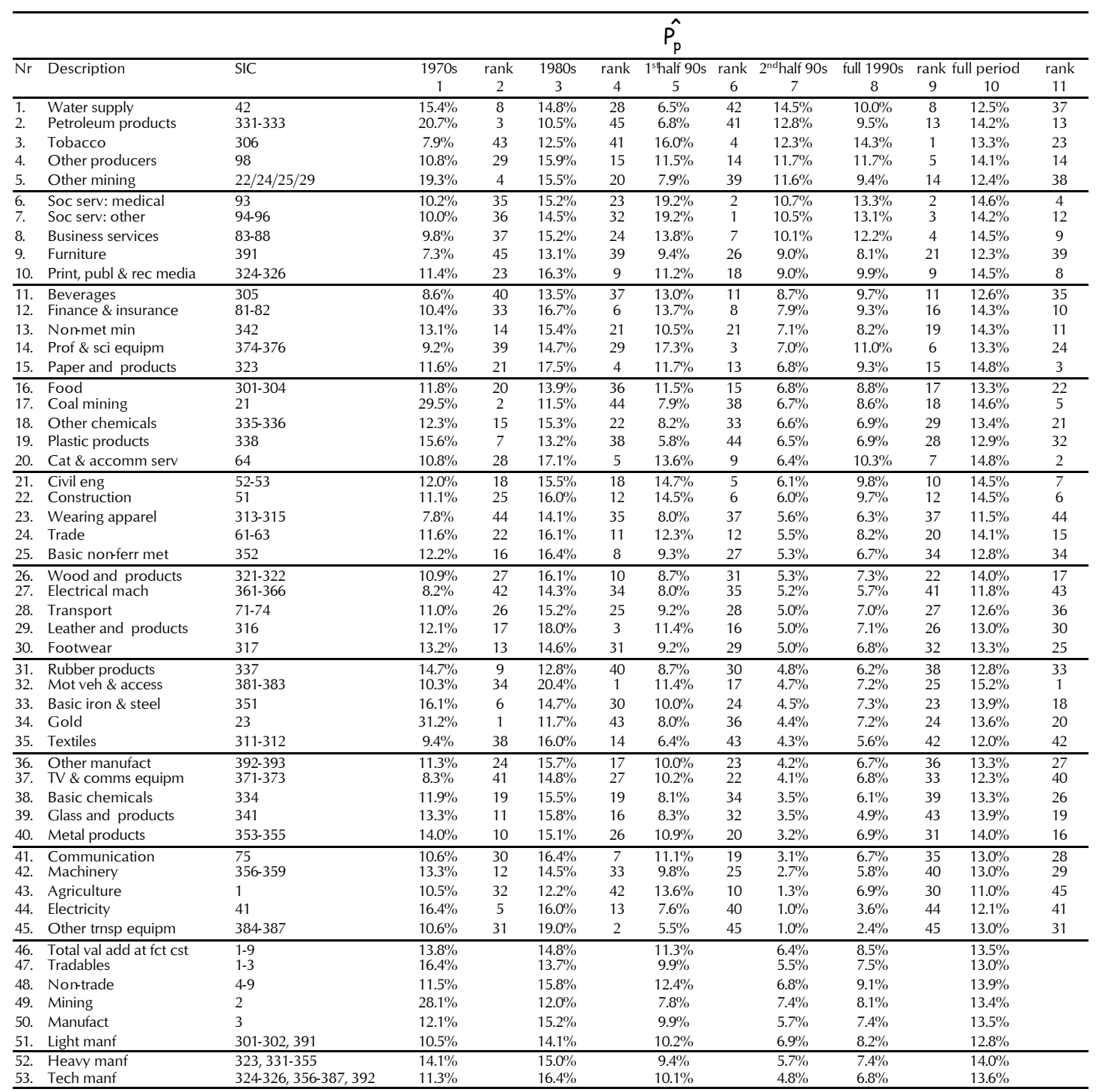

Source: TIPS South African Standardised Industrial Data Base and own calculations 
With an average producer price inflation of $8.5 \%$ in the $1990 \mathrm{~s}$, which, by the way, was lower than the $13.8 \%$ in the 1970 s and the $14.8 \%$ in the 1980 s, the second half of the 1990 s has seen a decline compared to the first half of the 1990s. The water supply, petroleum producers and tobacco products producers have seen the highest increase in producer prices in the second half of the 1990s. In all these industries prices are administered to a more or lesser degree and probably for good reasons. Other high increases in producer prices are recorded for social services, both medical and non-medical (see rows $6 \& 7$ ) as well as business and financial services (see rows $8 \& 12$ ).

Producer prices for electricity (row 44), agriculture (row 43), TV and communication equipment (row 37) as well as textiles (row 35) have been relatively low. In rows 47 and 48 it can be seen that prices of tradables have been rising less than prices for non-tradables. This is in particular true for technology manufacturing.

Nominal wage growth is shown in the next table. Nominal wage bill growth rankings will be the same to the real wage bill rankings; rankings, since in our set-up, the consumer price deflator is identical to all workers. Slight variations could have been considered based on population group variations in the consumer price deflator, while using sectoral employment by population group as the relevant weights. However, it was thought (although as yet not tested) that this would not create sufficient variation in a sectoral consumer price deflator.

A cursory glance at the next table suggests that sectoral ranking of the nominal wage bill is closely associated to that of nominal value added, the correlation coefficient for the actual growth rates for the second half of the 1990s is 0.78 . 
Table A 4: Change in the Nominal Wage Bill

\begin{tabular}{|c|c|c|c|c|c|c|c|c|c|c|c|c|c|}
\hline & & & & & & & $\hat{S_{w}}$ & & & & & & \\
\hline$\overline{\mathrm{Nr}}$ & Description & SIC & $\begin{array}{c}1970 \mathrm{~s} \\
1\end{array}$ & $\begin{array}{c}\text { rank } \\
2\end{array}$ & $\begin{array}{c}1980 \mathrm{~s} \\
3\end{array}$ & $\begin{array}{c}\text { rank } \\
4\end{array}$ & $\begin{array}{c}1^{\text {sh half } 90 \mathrm{~s}} \\
5\end{array}$ & $\begin{array}{c}\text { rank } \\
6\end{array}$ & $\begin{array}{c}2^{\text {nd }} \text { half } 90 \mathrm{~s} \\
7\end{array}$ & $\begin{array}{c}\text { full } 1990 \mathrm{~s} \\
8\end{array}$ & $\begin{array}{c}\text { rank } \\
9\end{array}$ & $\begin{array}{c}\text { full period } \\
10\end{array}$ & $\begin{array}{c}\text { rank } \\
11\end{array}$ \\
\hline $\begin{array}{l}1 . \\
2 .\end{array}$ & $\begin{array}{l}\text { TV \& comms equipm } \\
\text { Plastic products }\end{array}$ & $\begin{array}{l}371-373 \\
338\end{array}$ & $\begin{array}{l}16.8 \% \\
24.2 \%\end{array}$ & $\begin{array}{c}16 \\
3\end{array}$ & $\begin{array}{l}16.1 \% \\
18.4 \%\end{array}$ & $\begin{array}{l}19 \\
11\end{array}$ & $\begin{array}{c}11.2 \% \\
9.5 \%\end{array}$ & $\begin{array}{l}21 \\
29\end{array}$ & $\begin{array}{l}21.9 \% \\
21.6 \%\end{array}$ & $\begin{array}{l}13.2 \% \\
13.8 \%\end{array}$ & $\begin{array}{l}8 \\
5\end{array}$ & $\begin{array}{l}16.4 \% \\
18.4 \%\end{array}$ & $\begin{array}{c}11 \\
2\end{array}$ \\
\hline 3. & Wood and products & $321-322$ & $12.9 \%$ & 39 & $15.4 \%$ & 26 & $13.2 \%$ & 12 & $15.5 \%$ & $13.2 \%$ & 9 & $14.4 \%$ & 27 \\
\hline 4. & Business services & $83-88$ & $13.3 \%$ & 35 & $15.8 \%$ & 24 & $14.6 \%$ & 7 & $15.4 \%$ & $15.5 \%$ & 2 & $16.6 \%$ & 10 \\
\hline 5. & Print, publ \& rec media & $324-326$ & $13.1 \%$ & 36 & $14.2 \%$ & 30 & $11.3 \%$ & 20 & $14.4 \%$ & $10.0 \%$ & 17 & $14.4 \%$ & 28 \\
\hline $\begin{array}{l}6 . \\
7 .\end{array}$ & $\begin{array}{l}\text { Leather and products } \\
\text { Other chemicals }\end{array}$ & $\begin{array}{l}316 \\
335-336\end{array}$ & $\begin{array}{l}13.9 \% \\
21.6 \%\end{array}$ & $\begin{array}{c}27 \\
5\end{array}$ & $\begin{array}{l}14.6 \% \\
20.4 \%\end{array}$ & $\begin{array}{c}29 \\
4\end{array}$ & $\begin{array}{l}8.1 \% \\
8.2 \%\end{array}$ & $\begin{array}{l}34 \\
33\end{array}$ & $\begin{array}{l}13.9 \% \\
13.6 \%\end{array}$ & $\begin{array}{l}7.3 \% \\
10.2 \%\end{array}$ & $\begin{array}{l}32 \\
16\end{array}$ & $\begin{array}{l}12.3 \% \\
18.4 \%\end{array}$ & $\begin{array}{c}41 \\
3\end{array}$ \\
\hline 8. & Soc serv: medical & 93 & $13.3 \%$ & 34 & $24.0 \%$ & 1 & $20.4 \%$ & 1 & $13.0 \%$ & $16.9 \%$ & 1 & $20.6 \%$ & 1 \\
\hline 9. & Finance \& insurance & $81-82$ & $14.8 \%$ & 22 & $20.1 \%$ & 5 & $15.0 \%$ & 5 & $12.9 \%$ & $13.5 \%$ & 6 & $17.6 \%$ & 5 \\
\hline 10. & Other producers & 98 & $12.9 \%$ & 38 & $15.8 \%$ & 25 & $14.7 \%$ & 6 & $12.9 \%$ & $14.7 \%$ & 3 & $15.1 \%$ & 20 \\
\hline $\begin{array}{l}11 . \\
12 .\end{array}$ & $\begin{array}{l}\text { Other mining } \\
\text { Beverages }\end{array}$ & $\begin{array}{l}22 / 24 / 25 / 29 \\
305\end{array}$ & $\begin{array}{l}24.5 \% \\
17.5 \%\end{array}$ & $\begin{array}{c}2 \\
12\end{array}$ & $\begin{array}{l}15.9 \% \\
16.4 \%\end{array}$ & $\begin{array}{l}22 \\
17\end{array}$ & $\begin{array}{l}16.1 \% \\
8.0 \%\end{array}$ & $\begin{array}{c}4 \\
35\end{array}$ & $\begin{array}{l}12.3 \% \\
12.0 \%\end{array}$ & $\begin{array}{l}14.0 \% \\
9.4 \%\end{array}$ & $\begin{array}{c}4 \\
23\end{array}$ & $\begin{array}{l}17.0 \% \\
15.4 \%\end{array}$ & $\begin{array}{c}8 \\
19\end{array}$ \\
\hline 13. & Tobacco & 306 & $18.1 \%$ & 10 & $13.2 \%$ & 36 & $4.2 \%$ & 42 & $11.6 \%$ & $6.8 \%$ & 35 & $13.2 \%$ & 35 \\
\hline 14. & Wearing apparel & 313-315 & $13.0 \%$ & 37 & $13.8 \%$ & 31 & $13.9 \%$ & 9 & $10.8 \%$ & $12.0 \%$ & 10 & $14.2 \%$ & 30 \\
\hline 15. & Electricity & 41 & $18.4 \%$ & 9 & $21.3 \%$ & 2 & $10.0 \%$ & 26 & $10.1 \%$ & $11.5 \%$ & 12 & $17.4 \%$ & 6 \\
\hline $\begin{array}{l}16 . \\
17 .\end{array}$ & $\begin{array}{l}\text { Soc serv: other } \\
\text { Mot veh \& access }\end{array}$ & $\begin{array}{l}9496 \\
381-383\end{array}$ & $\begin{array}{l}13.5 \% \\
13.9 \%\end{array}$ & $\begin{array}{l}33 \\
28\end{array}$ & $\begin{array}{l}19.0 \% \\
17.0 \%\end{array}$ & $\begin{array}{c}9 \\
14\end{array}$ & $\begin{array}{l}16.9 \% \\
9.0 \%\end{array}$ & $\begin{array}{c}3 \\
30\end{array}$ & $\begin{array}{l}9.6 \% \\
9.5 \%\end{array}$ & $\begin{array}{l}13.3 \% \\
9.7 \%\end{array}$ & $\begin{array}{c}7 \\
20\end{array}$ & $\begin{array}{l}16.1 \% \\
14.9 \%\end{array}$ & $\begin{array}{l}12 \\
23\end{array}$ \\
\hline 18. & Rubber products & 337 & $16.6 \%$ & 19 & $13.5 \%$ & 33 & $11.6 \%$ & 17 & $9.4 \%$ & $7.3 \%$ & 33 & $13.2 \%$ & 34 \\
\hline 19. & Communication & 75 & $12.3 \%$ & 41 & $19.6 \%$ & 7 & $10.1 \%$ & 25 & $9.3 \%$ & $10.7 \%$ & 13 & $15.9 \%$ & 15 \\
\hline 20. & Basic chemicals & 334 & $16.2 \%$ & 20 & $20.4 \%$ & 3 & $7.3 \%$ & 38 & $9.2 \%$ & $8.2 \%$ & 26 & $17.3 \%$ & 7 \\
\hline $\begin{array}{l}21 . \\
22 .\end{array}$ & $\begin{array}{l}\text { Paper and products } \\
\text { Furniture }\end{array}$ & $\begin{array}{l}323 \\
391\end{array}$ & $\begin{array}{l}14.2 \% \\
13.7 \%\end{array}$ & $\begin{array}{l}26 \\
31\end{array}$ & $\begin{array}{l}18.7 \% \\
12.7 \%\end{array}$ & $\begin{array}{l}10 \\
38\end{array}$ & $\begin{array}{l}12.8 \% \\
18.7 \%\end{array}$ & $\begin{array}{c}15 \\
2\end{array}$ & $\begin{array}{l}9.0 \% \\
8.5 \%\end{array}$ & $\begin{array}{l}10.0 \% \\
10.6 \%\end{array}$ & $\begin{array}{l}18 \\
14\end{array}$ & $\begin{array}{l}16.0 \% \\
14.2 \%\end{array}$ & $\begin{array}{l}13 \\
29\end{array}$ \\
\hline 23. & Water supply & 42 & $9.9 \%$ & 44 & $11.3 \%$ & 40 & $13.4 \%$ & 10 & $8.1 \%$ & $11.6 \%$ & 11 & $15.6 \%$ & 17 \\
\hline 24. & Food & $301-304$ & $16.8 \%$ & 17 & $16.0 \%$ & 21 & $9.8 \%$ & 28 & $8.1 \%$ & $8.1 \%$ & 28 & $14.9 \%$ & 22 \\
\hline 25. & Transport & $71-74$ & $14.6 \%$ & 23 & $10.8 \%$ & 42 & $10.7 \%$ & 23 & $7.7 \%$ & $10.3 \%$ & 15 & $13.0 \%$ & 36 \\
\hline $\begin{array}{l}26 . \\
27 .\end{array}$ & $\begin{array}{l}\text { Trade } \\
\text { Cat \& accomm serv }\end{array}$ & $\begin{array}{l}61-63 \\
64\end{array}$ & $\begin{array}{l}15.2 \% \\
12.3 \%\end{array}$ & $\begin{array}{l}21 \\
42\end{array}$ & $\begin{array}{l}16.9 \% \\
19.5 \%\end{array}$ & $\begin{array}{c}15 \\
8\end{array}$ & $\begin{array}{l}11.5 \% \\
11.5 \%\end{array}$ & $\begin{array}{l}19 \\
18\end{array}$ & $\begin{array}{l}7.4 \% \\
7.4 \%\end{array}$ & $\begin{array}{l}9.4 \% \\
9.4 \%\end{array}$ & $\begin{array}{l}21 \\
22\end{array}$ & $\begin{array}{l}15.8 \% \\
15.9 \%\end{array}$ & $\begin{array}{l}16 \\
14\end{array}$ \\
\hline 28. & Electrical mach & $361-366$ & $17.9 \%$ & 11 & $13.2 \%$ & 35 & $13.1 \%$ & 13 & $7.0 \%$ & $7.8 \%$ & 30 & $14.8 \%$ & 24 \\
\hline 29. & Agriculture & 1 & $13.6 \%$ & 32 & $12.7 \%$ & 39 & $12.6 \%$ & 16 & $6.0 \%$ & $9.2 \%$ & 24 & $12.5 \%$ & 38 \\
\hline 30. & Machinery & $356-359$ & $17.1 \%$ & 13 & $9.3 \%$ & 45 & $8.4 \%$ & 32 & $5.7 \%$ & $8.3 \%$ & 25 & $12.3 \%$ & 40 \\
\hline $\begin{array}{l}31 . \\
32 .\end{array}$ & $\begin{array}{l}\text { Prof \& sci equipm } \\
\text { Civil eng }\end{array}$ & $\begin{array}{l}374-376 \\
52-53\end{array}$ & $\begin{array}{l}12.5 \% \\
16.6 \%\end{array}$ & $\begin{array}{l}40 \\
18\end{array}$ & $\begin{array}{l}18.3 \% \\
10.4 \%\end{array}$ & $\begin{array}{l}12 \\
43\end{array}$ & $\begin{array}{l}10.0 \% \\
7.8 \%\end{array}$ & $\begin{array}{l}27 \\
37\end{array}$ & $\begin{array}{l}5.6 \% \\
5.0 \%\end{array}$ & $\begin{array}{l}5.9 \% \\
6.3 \%\end{array}$ & $\begin{array}{l}38 \\
36\end{array}$ & $\begin{array}{l}14.7 \% \\
12.0 \%\end{array}$ & $\begin{array}{l}26 \\
42\end{array}$ \\
\hline $\begin{array}{l}32 . \\
33 .\end{array}$ & $\begin{array}{l}\text { Civil eng } \\
\text { Other manufact }\end{array}$ & $\begin{array}{l}52-53 \\
392-393\end{array}$ & $\begin{array}{l}16.6 \% \\
11.4 \%\end{array}$ & $\begin{array}{l}18 \\
43\end{array}$ & $\begin{array}{l}10.4 \% \\
18.3 \%\end{array}$ & $\begin{array}{l}43 \\
13\end{array}$ & $\begin{array}{l}.0 \% \\
13.0 \%\end{array}$ & 14 & $\begin{array}{l}5.0 \% \\
4.3 \%\end{array}$ & $\begin{array}{l}0.370 \\
8.2 \%\end{array}$ & 27 & $15.0 \%$ & $\begin{array}{l}42 \\
21\end{array}$ \\
\hline 34. & Construction & 51 & $7.8 \%$ & 45 & $15.2 \%$ & 27 & $7.9 \%$ & 36 & $4.2 \%$ & $6.1 \%$ & 37 & $12.7 \%$ & 37 \\
\hline 35. & Coal mining & 21 & $28.6 \%$ & 1 & $15.1 \%$ & 28 & $5.5 \%$ & 40 & $3.7 \%$ & $7.7 \%$ & 31 & $16.7 \%$ & 9 \\
\hline $\begin{array}{l}36 . \\
37 .\end{array}$ & $\begin{array}{l}\text { Glass and products } \\
\text { Textiles }\end{array}$ & $\begin{array}{l}341 \\
311-312\end{array}$ & $\begin{array}{l}13.9 \% \\
14.6 \%\end{array}$ & $\begin{array}{l}29 \\
24\end{array}$ & $\begin{array}{l}16.1 \% \\
12.8 \%\end{array}$ & $\begin{array}{l}20 \\
37\end{array}$ & $\begin{array}{l}14.1 \% \\
4.2 \%\end{array}$ & $\begin{array}{c}8 \\
43\end{array}$ & $\begin{array}{l}3.5 \% \\
3.2 \%\end{array}$ & $\begin{array}{l}9.9 \% \\
7.1 \%\end{array}$ & $\begin{array}{l}19 \\
34\end{array}$ & $\begin{array}{l}15.6 \% \\
11.7 \%\end{array}$ & $\begin{array}{l}18 \\
43\end{array}$ \\
\hline 38. & Metal products & $353-355$ & $17.1 \%$ & 14 & $10.1 \%$ & 44 & $10.5 \%$ & 24 & $2.2 \%$ & $7.9 \%$ & 29 & $12.3 \%$ & 39 \\
\hline 39. & Petroleum products & $331-333$ & $19.5 \%$ & 7 & $20.1 \%$ & 6 & $8.9 \%$ & 31 & $1.2 \%$ & $5.3 \%$ & 40 & $17.6 \%$ & 4 \\
\hline 40. & Gold & 23 & $23.3 \%$ & 4 & $15.8 \%$ & 23 & $4.2 \%$ & 44 & $-0.2 \%$ & $3.0 \%$ & 43 & $14.0 \%$ & 31 \\
\hline $\begin{array}{l}41 . \\
42 .\end{array}$ & $\begin{array}{l}\text { Basic iron \& steel } \\
\text { Basic nonferr met }\end{array}$ & $\begin{array}{l}351 \\
352\end{array}$ & $\begin{array}{l}20.6 \% \\
16.9 \%\end{array}$ & $\begin{array}{l}6 \\
15\end{array}$ & $\begin{array}{l}13.6 \% \\
16.6 \%\end{array}$ & $\begin{array}{l}32 \\
16\end{array}$ & $\begin{array}{l}7.1 \% \\
13.3 \%\end{array}$ & $\begin{array}{l}39 \\
11\end{array}$ & $\begin{array}{l}-0.8 \% \\
-2.6 \%\end{array}$ & $\begin{array}{l}4.6 \% \\
5.6 \%\end{array}$ & $\begin{array}{l}41 \\
39\end{array}$ & $13.3 \%$ & $\begin{array}{l}33 \\
25\end{array}$ \\
\hline 43. & $\begin{array}{l}\text { Basic non-terr met } \\
\text { Non-met min }\end{array}$ & $\begin{array}{l}352 \\
342\end{array}$ & $\begin{array}{l}16.9 \% \\
13.8 \%\end{array}$ & 30 & $\begin{array}{l}16.6 \% \\
16.2 \%\end{array}$ & 18 & $\begin{array}{l}13.3 \% \\
10.8 \%\end{array}$ & 22 & $\begin{array}{l}-2.6 \% \\
-3.9 \%\end{array}$ & $\begin{array}{l}3.07 \% \\
4.2 \%\end{array}$ & 42 & $13.8 \%$ & 32 \\
\hline 44. & Other trnsp equipm & 384387 & $19.2 \%$ & 8 & $11.0 \%$ & 41 & $0.4 \%$ & 45 & $-7.8 \%$ & $-2.3 \%$ & 45 & $9.9 \%$ & 45 \\
\hline 45. & Footwear & 317 & $14.4 \%$ & 25 & $13.4 \%$ & 34 & $5.3 \%$ & 41 & $-8.4 \%$ & $-0.6 \%$ & 44 & $11.3 \%$ & 44 \\
\hline $\begin{array}{l}46 . \\
47 .\end{array}$ & $\begin{array}{l}\text { Total val add at fct cst } \\
\text { Tradables }\end{array}$ & $\begin{array}{l}1-9 \\
1-3\end{array}$ & $\begin{array}{l}15.5 \% \\
17.5 \%\end{array}$ & & $\begin{array}{l}15.3 \% \\
14.8 \%\end{array}$ & & $\begin{array}{c}11.1 \% \\
9.5 \%\end{array}$ & & $\begin{array}{l}8.6 \% \\
6.6 \%\end{array}$ & $\begin{array}{l}10.1 \% \\
8.1 \%\end{array}$ & & $\begin{array}{l}14.9 \% \\
14.3 \%\end{array}$ & \\
\hline 48. & Non-trade & 49 & $13.9 \%$ & & $15.8 \%$ & & $12.2 \%$ & & $9.9 \%$ & $11.4 \%$ & & $15.2 \%$ & \\
\hline 49. & Mining & 2 & $24.2 \%$ & & $15.7 \%$ & & $7.4 \%$ & & $4.7 \%$ & $7.0 \%$ & & $15.2 \%$ & \\
\hline 50. & Manufact & 3 & $16.3 \%$ & & $14.7 \%$ & & $9.9 \%$ & & $7.2 \%$ & $8.4 \%$ & & $14.3 \%$ & \\
\hline 51. & Light manf & $301-302,391$ & $15.7 \%$ & & $14.9 \%$ & & $9.9 \%$ & & $9.3 \%$ & $9.3 \%$ & & $14.4 \%$ & \\
\hline 52. & Heavy manf & $323,331-355$ & $17.4 \%$ & & $15.3 \%$ & & $9.7 \%$ & & $5.2 \%$ & $7.7 \%$ & & $14.6 \%$ & \\
\hline 53. & Tech manf & $324-326,356-387,392$ & $15.5 \%$ & & $13.7 \%$ & & $10.3 \%$ & & $7.9 \%$ & $8.4 \%$ & & $14.0 \%$ & \\
\hline
\end{tabular}

Source: TIPS South African Standardised Industrial Data Base and own calculations 
Industries with the highest increases in the nominal wage bill during the second half of the 1990s are TV and communications equipment, plastics and wood and product producers, followed by business services and printing and publishing. Wage bill decreases over the same period are recorded for footwear, other transport equipment, non-metallic minerals and basic metals producers. On the whole, the tradables industries have experienced a lower nominal wage bill increases compared to non-tradable producers. In terms of manufacturing, the heavy and technology products producers have seen a relatively low increase compared to the light manufacturing producers. The services producers have also seen a relatively high increase in the nominal wage bill.

For all sectors (see row 46) the wage bill grew at more or less the same rates than value added (see same row in ). However, in the case of tradables, the nominal wage bill grew at a faster rate, while for non-tradables, the wage bill lagged slightly. This suggests that the functional distribution of income has turned in favour of labour for tradables and in favour of capital, at least during the second half of the 1990s. A comparison of nominal wage growth and nominal value added growth is embedded in the $\alpha$ coefficient defined in equation 2 above. The values are shown in table below. If $\alpha$ is larger than unity, the nominal wage bill has increased at a faster rate than nominal value added. 
Table A 5: Technological and Behavioural Parameter, the Ratio of Nominal Growth in the Wage Bill and Value Added

\begin{tabular}{|c|c|c|c|c|c|c|c|c|c|c|c|c|c|}
\hline & & & & & & & $\alpha$ & & & & & & \\
\hline $\mathrm{Nr}$ & Description & SIC & $\begin{array}{c}1970 \mathrm{~s} \\
1\end{array}$ & $\begin{array}{c}\text { rank } \\
2\end{array}$ & $\begin{array}{c}1980 \mathrm{~s} \\
3\end{array}$ & $\begin{array}{c}\text { rank } \\
4\end{array}$ & $\begin{array}{l}1^{\text {sh half } 90 \mathrm{~s}} \\
5\end{array}$ & $\begin{array}{c}\text { rank } \\
6\end{array}$ & $\begin{array}{c}2^{\text {nd half } 90 \mathrm{~s}} \\
7\end{array}$ & $\begin{array}{c}\text { full 1990s } \\
8\end{array}$ & $\begin{array}{c}\text { rank } \\
9\end{array}$ & $\begin{array}{c}\text { full period } \\
10\end{array}$ & $\begin{array}{c}\text { rank } \\
11\end{array}$ \\
\hline $\begin{array}{l}1 . \\
2 .\end{array}$ & $\begin{array}{l}\text { Agriculture } \\
\text { Electricity }\end{array}$ & $\begin{array}{l}1 \\
41\end{array}$ & $\begin{array}{l}1.02 \\
0.76\end{array}$ & $\begin{array}{l}11 \\
44\end{array}$ & $\begin{array}{l}0.84 \\
1.00\end{array}$ & $\begin{array}{l}37 \\
15\end{array}$ & $\begin{array}{l}1.12 \\
0.91\end{array}$ & $\begin{array}{c}9 \\
22\end{array}$ & $\begin{array}{l}7.32 \\
2.93\end{array}$ & $\begin{array}{l}1.22 \\
1.64\end{array}$ & $\begin{array}{c}10 \\
5\end{array}$ & $\begin{array}{l}1.02 \\
1.00\end{array}$ & $\begin{array}{l}7 \\
15\end{array}$ \\
\hline 3. & Leather and products & 316 & 0.96 & 26 & 0.79 & 44 & 0.74 & 36 & 2.13 & 1.64 & 6 & 0.88 & 42 \\
\hline 4. & Paper and products & 323 & 0.90 & 35 & 0.80 & 41 & 0.88 & 25 & 2.03 & 1.08 & 14 & 0.90 & 38 \\
\hline 5. & TV \& comms equipm & $371-373$ & 0.89 & 36 & 0.93 & 23 & 1.20 & 4 & 1.99 & 1.61 & 7 & 1.00 & 11 \\
\hline $\begin{array}{l}6 . \\
7 .\end{array}$ & $\begin{array}{l}\text { Food } \\
\text { Beverages }\end{array}$ & $\begin{array}{l}301-304 \\
305\end{array}$ & $\begin{array}{l}0.99 \\
1.10\end{array}$ & $\begin{array}{c}18 \\
4\end{array}$ & $\begin{array}{l}1.04 \\
0.85\end{array}$ & $\begin{array}{l}7 \\
34\end{array}$ & $\begin{array}{l}0.95 \\
0.55\end{array}$ & $\begin{array}{l}20 \\
41\end{array}$ & $\begin{array}{l}1.81 \\
1.61\end{array}$ & $\begin{array}{l}1.12 \\
0.75\end{array}$ & $\begin{array}{l}12 \\
37\end{array}$ & $\begin{array}{l}1.01 \\
0.91\end{array}$ & $\begin{array}{c}9 \\
35\end{array}$ \\
\hline 8. & Cat \& accomm serv & 64 & 1.31 & 2 & 0.84 & 38 & 0.84 & 28 & 1.56 & 0.92 & 29 & 0.90 & 37 \\
\hline 9. & Wood and products & $321-322$ & 0.95 & 28 & 0.94 & 22 & 0.96 & 19 & 1.50 & 1.13 & 11 & 0.95 & 30 \\
\hline 10. & Wearing apparel & $313-315$ & 1.03 & 10 & 0.93 & 24 & 1.09 & 10 & 1.38 & 1.32 & 9 & 1.01 & 8 \\
\hline $\begin{array}{l}1 . \\
12 .\end{array}$ & $\begin{array}{l}\text { Print, publ \& rec media } \\
\text { Tobacco }\end{array}$ & $\begin{array}{l}324326 \\
306\end{array}$ & $\begin{array}{l}0.97 \\
1.62\end{array}$ & $\begin{array}{c}22 \\
1\end{array}$ & $\begin{array}{l}0.93 \\
1.03\end{array}$ & $\begin{array}{c}25 \\
8\end{array}$ & $\begin{array}{l}0.84 \\
0.27\end{array}$ & $\begin{array}{l}29 \\
45\end{array}$ & $\begin{array}{l}1.35 \\
1.34\end{array}$ & $\begin{array}{l}0.95 \\
0.49\end{array}$ & $\begin{array}{l}24 \\
43\end{array}$ & $\begin{array}{l}0.95 \\
0.96\end{array}$ & $\begin{array}{l}29 \\
23\end{array}$ \\
\hline 13. & Furniture & 391 & 1.03 & 9 & 0.91 & 28 & 1.52 & 2 & 1.20 & 1.56 & 8 & 1.01 & 10 \\
\hline 14. & Plastic products & 338 & 0.99 & 19 & 1.01 & 13 & 0.89 & 23 & 1.15 & 0.99 & 20 & 0.98 & 20 \\
\hline 15. & Electrical mach & $361-366$ & 1.01 & 13 & 1.00 & 14 & 1.18 & 5 & 1.14 & 0.99 & 21 & 1.00 & 14 \\
\hline $\begin{array}{l}16 . \\
17 .\end{array}$ & $\begin{array}{l}\text { Business services } \\
\text { Rubber products }\end{array}$ & $\begin{array}{l}83-88 \\
337\end{array}$ & $\begin{array}{l}1.18 \\
0.99\end{array}$ & $\begin{array}{c}3 \\
17\end{array}$ & $\begin{array}{l}1.17 \\
1.01\end{array}$ & $\begin{array}{c}5 \\
12\end{array}$ & $\begin{array}{l}0.87 \\
1.03\end{array}$ & $\begin{array}{l}26 \\
15\end{array}$ & $\begin{array}{l}1.13 \\
1.12\end{array}$ & $\begin{array}{l}1.00 \\
0.96\end{array}$ & $\begin{array}{l}19 \\
23\end{array}$ & $\begin{array}{l}1.03 \\
0.99\end{array}$ & $\begin{array}{c}6 \\
18\end{array}$ \\
\hline 18. & Other trnsp equipm & 384387 & 1.05 & 7 & 0.99 & 18 & 0.29 & 44 & 1.11 & 2.39 & 3 & 0.99 & 16 \\
\hline 19. & Machinery & $356-359$ & 1.06 & 6 & 0.86 & 33 & 0.99 & 17 & 1.11 & 0.99 & 22 & 0.96 & 26 \\
\hline 20. & Trade & $61-63$ & 1.06 & 5 & 0.98 & 19 & 0.83 & 32 & 1.10 & 0.93 & 27 & 0.99 & 17 \\
\hline $\begin{array}{l}21 . \\
22 .\end{array}$ & $\begin{array}{l}\text { Other chemicals } \\
\text { Soc serv: medical }\end{array}$ & $\begin{array}{l}335-336 \\
93\end{array}$ & $\begin{array}{l}1.04 \\
0.92\end{array}$ & $\begin{array}{c}8 \\
32\end{array}$ & $\begin{array}{l}0.99 \\
1.21\end{array}$ & $\begin{array}{c}17 \\
3\end{array}$ & $\begin{array}{l}0.70 \\
0.76\end{array}$ & $\begin{array}{l}37 \\
34\end{array}$ & $\begin{array}{l}1.08 \\
1.05\end{array}$ & $\begin{array}{l}0.79 \\
0.91\end{array}$ & $\begin{array}{l}33 \\
30\end{array}$ & $\begin{array}{l}0.96 \\
1.05\end{array}$ & $\begin{array}{c}22 \\
5\end{array}$ \\
\hline 23. & Transport & $71-74$ & 0.85 & 41 & 0.73 & 45 & 0.87 & 27 & 1.03 & 1.01 & 16 & 0.88 & 41 \\
\hline 24. & Other producer s & 98 & 1.01 & 12 & 1.00 & 16 & 1.00 & 16 & 1.01 & 1.01 & 17 & 1.00 & 13 \\
\hline 25. & Soc serv: other & 9496 & 0.93 & 30 & 1.19 & 4 & 0.75 & 35 & 1.01 & 0.90 & 32 & 0.98 & 19 \\
\hline 26. & Metal products & $353-355$ & 1.00 & 15 & 0.97 & 20 & 0.97 & 18 & 1.00 & 0.93 & 26 & 0.95 & 27 \\
\hline 27. & Basic chemicals & & 0.96 & 25 & 0.93 & 26 & 0.89 & 24 & 0.97 & 0.78 & 35 & 0.97 & 21 \\
\hline 28. & Mot veh \& access & $381-383$ & 0.94 & 29 & 0.79 & 43 & 0.83 & 30 & 0.96 & 1.04 & 15 & 0.89 & 40 \\
\hline 29. & Construction & 51 & 0.95 & 27 & 1.02 & 10 & 0.65 & 39 & 0.83 & 0.64 & 38 & 0.93 & 33 \\
\hline 30. & Coal mining & 21 & 0.78 & 43 & 1.14 & 6 & 0.48 & 43 & 0.83 & 0.76 & 36 & 1.00 & 12 \\
\hline $\begin{array}{l}31 . \\
32 .\end{array}$ & $\begin{array}{l}\text { Finance \& insurance } \\
\text { Other manufact }\end{array}$ & $\begin{array}{l}81-82 \\
392-393\end{array}$ & $\begin{array}{l}0.86 \\
0.79\end{array}$ & $\begin{array}{l}40 \\
42\end{array}$ & $\begin{array}{l}0.83 \\
0.83\end{array}$ & $\begin{array}{l}39 \\
40\end{array}$ & $\begin{array}{l}1.06 \\
1.07\end{array}$ & $\begin{array}{l}14 \\
13\end{array}$ & $\begin{array}{l}0.82 \\
0.79\end{array}$ & $\begin{array}{l}0.92 \\
0.95\end{array}$ & $\begin{array}{l}28 \\
25\end{array}$ & $\begin{array}{l}0.94 \\
0.90\end{array}$ & $\begin{array}{l}31 \\
36\end{array}$ \\
\hline 33. & Civil eng & $52-53$ & 0.97 & 23 & 0.92 & 27 & 0.58 & 40 & 0.77 & 0.58 & 40 & 0.89 & 39 \\
\hline 34. & Footwear & 317 & 0.93 & 31 & 0.88 & 32 & 1.20 & 3 & 0.74 & 0.16 & 45 & 0.96 & 25 \\
\hline 35. & Other mining & $22 / 24 / 25 / 29$ & 0.91 & 34 & 0.89 & 30 & 1.07 & 12 & 0.69 & 1.01 & 18 & 1.12 & 3 \\
\hline 36. & Glass and products & 341 & 0.87 & 38 & $\begin{array}{l}0.88 \\
0.80\end{array}$ & $\begin{array}{l}31 \\
42\end{array}$ & $\begin{array}{l}1.07 \\
0.53\end{array}$ & $\begin{array}{l}11 \\
42\end{array}$ & $\begin{array}{l}0.57 \\
0.49\end{array}$ & $\begin{array}{l}1.11 \\
0.51\end{array}$ & $\begin{array}{l}13 \\
42\end{array}$ & $\begin{array}{l}0.92 \\
0.81\end{array}$ & $\begin{array}{l}34 \\
45\end{array}$ \\
\hline $\begin{array}{l}37 . \\
38 .\end{array}$ & $\begin{array}{l}\text { Communication } \\
\text { Water supply }\end{array}$ & $\begin{array}{l}75 \\
42\end{array}$ & $\begin{array}{l}0.98 \\
0.59\end{array}$ & $\begin{array}{l}20 \\
45\end{array}$ & $\begin{array}{l}0.80 \\
1.02\end{array}$ & $\begin{array}{c}42 \\
9\end{array}$ & $\begin{array}{l}0.53 \\
1.13\end{array}$ & $\begin{array}{c}42 \\
7\end{array}$ & $\begin{array}{l}0.49 \\
0.45\end{array}$ & $\begin{array}{l}0.51 \\
0.78\end{array}$ & $\begin{array}{l}42 \\
34\end{array}$ & $\begin{array}{l}0.81 \\
1.17\end{array}$ & $\begin{array}{c}45 \\
2\end{array}$ \\
\hline & Petroleum products & $331-333$ & 0.91 & 33 & 1.25 & 2 & 1.13 & 8 & 0.35 & 0.90 & 31 & 0.96 & 24 \\
\hline 40. & Gold & 23 & 0.89 & 37 & 1.81 & 1 & 1.91 & 1 & 0.05 & 2.95 & 1 & 1.31 & 1 \\
\hline $\begin{array}{l}4 . \\
42 .\end{array}$ & $\begin{array}{l}\text { Basic iron \& steel } \\
\text { Basic nonferr met }\end{array}$ & $\begin{array}{l}351 \\
352\end{array}$ & $\begin{array}{l}0.97 \\
0.87\end{array}$ & $\begin{array}{l}24 \\
39\end{array}$ & $\begin{array}{l}0.84 \\
0.85\end{array}$ & $\begin{array}{l}36 \\
35\end{array}$ & $\begin{array}{l}0.69 \\
0.83\end{array}$ & $\begin{array}{l}38 \\
31\end{array}$ & $\begin{array}{l}-0.29 \\
-0.81\end{array}$ & $\begin{array}{l}0.56 \\
0.45\end{array}$ & $\begin{array}{l}41 \\
44\end{array}$ & $\begin{array}{l}0.88 \\
0.82\end{array}$ & $\begin{array}{l}43 \\
44\end{array}$ \\
\hline 43. & Prof \& sci equipm & $374-376$ & 0.99 & 16 & 0.90 & 29 & 0.94 & 21 & -1.43 & 2.19 & 4 & 0.95 & 28 \\
\hline 44. & Textiles & $311-312$ & 1.00 & 14 & 0.96 & 21 & 1.16 & 6 & -2.54 & 2.48 & 2 & 1.06 & 4 \\
\hline 45. & Non-met min & 342 & 0.98 & 21 & 1.01 & 11 & 0.83 & 33 & -7.15 & 0.62 & 39 & 0.94 & 32 \\
\hline 46. & Total val add at fct cst & $1-9$ & 0.92 & & 0.96 & & 0.86 & & 0.99 & 0.91 & & 0.97 & \\
\hline & Tradables & $1-3$ & 0.91 & & 1.00 & & 0.92 & & 1.16 & 0.96 & & 1.01 & \\
\hline & Non-trade & 49 & 0.95 & & 0.91 & & 0.83 & & 0.94 & 0.89 & & 0.94 & \\
\hline 49. & Mining & 2 & 0.88 & & 1.38 & & 0.89 & & 0.70 & 0.90 & & 1.16 & \\
\hline 50. & Manufact & 3 & 0.98 & & 0.90 & & 0.91 & & 1.15 & 0.94 & & 0.93 & \\
\hline 51. & Light manf & 301-302, 391 & 1.00 & & 0.95 & & 0.92 & & 1.45 & 1.09 & & 0.97 & \\
\hline 52. & Heavy manf & $323,331-355$ & 0.99 & & 0.83 & & 0.97 & & 1.12 & 0.99 & & 0.93 & \\
\hline 53. & Tech manf & $324-326,356-387,392$ & 0.95 & & 0.91 & & 0.83 & & 0.94 & 0.89 & & 0.94 & \\
\hline
\end{tabular}

Source: TIPS South African Standardised Industrial Data Base and own calculations 
The industries, where the growth in the mminal wage bill has outstripped the growth in nominal value added, are listed at the top of the table. They include sectors such as agriculture, electricity, leather products, paper products and TV and communications equipment producers. It is in these sectors that the share of labour in value added has increased during the second half of the 1990s. The opposite has taken place in industries listed towards the bottom of the industry ranking, including gold, basic metals, and textiles. In these industries, labour has been losing its share in value added. As mentioned above, tradables industries (including manufacturing as a whole and broken down into main components light, heavy and technology) have seen an increase in the share of labour while non-tradables and services have seen an increase in the share of capital.

Armed with the ingredients we can now turn to the application of equation 7. First we present results for the output effect. We expect that with a higher wage share, $\alpha$, and positive growth in value added, $\hat{v}$, the impact on real wage growth to be positive. Conversely, if growth in value added is negative, real wage growth will be affected negatively. The results are shown in the next table.

On average, the output effect on real wage growth has been positive during the second half of the 1990s as can be seen in row 46. The output effect has been higher than during the first half of the decade as well as the 1980. This growth can be attributed to non-tradables as opposed to tradables (see rows 48 and 47 respectively). In terms of manufacturing, positive output growth contributions to real wage increases have mainly been generated by technology intensive industries, while heavy industry has made no contribution and light manufacturing a negative contribution to real wage growth. Nevertheless, some light manufacturing such as plastic products (row 3) and textiles (row 4) show relatively high contributions, but these are off-set by negative contributions by industries such as food (row 41) and footwear (row 45). Similarly, with regards to heavy industries the positive contributions by non-metallic minerals (row 1 ) is counter balanced by negative growth in the coal mining (row 35), petroleum products (row 39) and paper (row 42) sectors. 
Table A 6: The Output Effect on Real Wage Growth

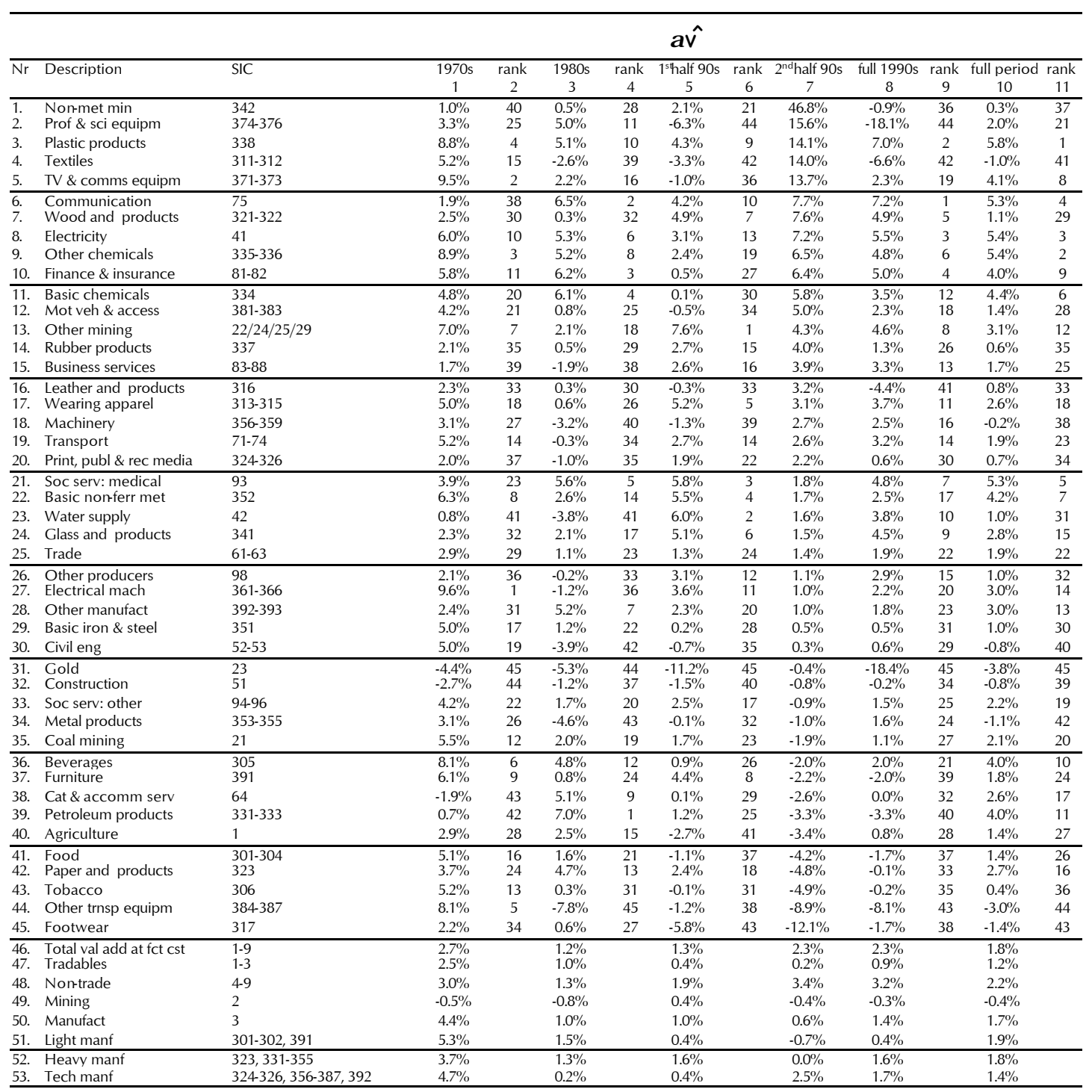

Source: TIPS South African Standardised Industrial Data Base and own calculations 
The employment effect, shown in the next table, is straightforward, in that it records the growth in employment. With higher employment growth, real wage growth will be affected negatively, since the wage bill will be shared with more workers. Typical to the insider-outsider dilemma, negative employment growth will have a positive impact on real wage growth.

On the whole, all sectors together have over the entire period barely experienced an increase in their labour absorption capacity. Row 39 shows that while employment grew by almost $2 \%$ in 1970 , this had declined to $0.2 \%$ during the $1980 \mathrm{~s}$ and it turned negative $1.6 \%$ in the first half of the 1990s. The second half of the 1990s produced the worst performance with a $-2.6 \%$ decline. Tradables and non-tradables show the same pattern but the latter is always better off, showing higher or less negative growth rates. In rows $50-53$ it can be seen that while manufacturing as a whole shows a similar trend as for all sectors together, the picture is slightly rosier. Interestingly, the performance of the technology-rich manufacturing sectors was better than the other manufacturing sectors during the first half of the 1990s but this turned around during the second half of the 1990s. Disastrous employment performances during the second half of the 1990s are recorded by textiles, glass and products, other transport equipment, construction, footwear, basic iron \& steel and gold (rows 38 - 44). 
Table A 7: The Employment Effect on Real Wage Growth

\begin{tabular}{|c|c|c|c|c|c|c|c|c|c|c|c|c|c|}
\hline & & & & & & & $\hat{L}$ & & & & & & \\
\hline$\overline{\mathrm{Nr}}$ & Description & SIC & $\begin{array}{c}1970 \mathrm{~s} \\
1\end{array}$ & $\begin{array}{c}\text { rank } \\
2\end{array}$ & $\begin{array}{c}1980 \mathrm{~s} \\
3\end{array}$ & $\begin{array}{c}\text { rank } \\
4\end{array}$ & $\begin{array}{c}1^{\text {sh half } 90 \mathrm{~s}} \\
5\end{array}$ & $\begin{array}{c}\text { rank } \\
6\end{array}$ & $\begin{array}{c}2^{\text {nd half } 90 \mathrm{~s}} \\
7\end{array}$ & $\begin{array}{c}\text { full } 1990 \mathrm{~s} \\
8\end{array}$ & $\begin{array}{c}\text { rank } \\
9\end{array}$ & $\begin{array}{c}\text { full period } \\
10\end{array}$ & $\begin{array}{c}\text { rank } \\
11\end{array}$ \\
\hline$\overline{1 .}$ & Leather and products & 316 & $1.9 \%$ & 27 & $2.4 \%$ & 10 & $-5.3 \%$ & 37 & $7.6 \%$ & $\begin{array}{c}0 \\
-2.5 \%\end{array}$ & 25 & $-0.1 \%$ & 26 \\
\hline 2. & Plastic products & 338 & $5.5 \%$ & 2 & $4.7 \%$ & 1 & $0.2 \%$ & 15 & $6.9 \%$ & $2.9 \%$ & 1 & $4.5 \%$ & 1 \\
\hline 3. & Wood and products & $321-322$ & $1.3 \%$ & 31 & $1.3 \%$ & 15 & $2.9 \%$ & 4 & $5.6 \%$ & $2.7 \%$ & 2 & $1.4 \%$ & 15 \\
\hline 4. & Trade & $61-63$ & $2.7 \%$ & 23 & $0.5 \%$ & 27 & $-1.4 \%$ & 23 & $4.8 \%$ & $1.4 \%$ & 7 & $0.8 \%$ & 20 \\
\hline 5. & Print, publ \& rec media & $324-326$ & $2.4 \%$ & 25 & $1.3 \%$ & 16 & $0.6 \%$ & 13 & $4.7 \%$ & $1.3 \%$ & 8 & $1.8 \%$ & 8 \\
\hline$\overline{6 .}$ & Soc serv: medical & 93 & $3.6 \%$ & 11 & $2.5 \%$ & 9 & $1.0 \%$ & 10 & $4.1 \%$ & $0.2 \%$ & 11 & $1.7 \%$ & 9 \\
\hline 7. & Soc serv: other & 9496 & $2.4 \%$ & 24 & $2.1 \%$ & 11 & $3.0 \%$ & 3 & $3.8 \%$ & $1.5 \%$ & 6 & $0.5 \%$ & 24 \\
\hline 8. & Other chemicals & $335-336$ & $3.5 \%$ & 14 & $2.1 \%$ & 12 & $-1.7 \%$ & 25 & $2.5 \%$ & $-0.3 \%$ & 16 & $1.9 \%$ & 7 \\
\hline 9. & TV \& comms equipm & $371-373$ & $5.4 \%$ & 4 & $-0.1 \%$ & 31 & $0.0 \%$ & 16 & $2.4 \%$ & $1.6 \%$ & 4 & $2.2 \%$ & 6 \\
\hline 10. & Other producers & 98 & $3.6 \%$ & 12 & $2.5 \%$ & 8 & $1.0 \%$ & 11 & $2.2 \%$ & $-0.1 \%$ & 14 & $1.7 \%$ & 11 \\
\hline 11. & Basic chemicals & 334 & $4.7 \%$ & 6 & $1.2 \%$ & 18 & $-2.4 \%$ & 28 & $2.0 \%$ & $-0.7 \%$ & 17 & $1.5 \%$ & 14 \\
\hline 12. & Business services & $83-88$ & $5.5 \%$ & 3 & $3.8 \%$ & 5 & $1.6 \%$ & 7 & $1.0 \%$ & $1.6 \%$ & 5 & $3.6 \%$ & 2 \\
\hline 13. & Electricity & 41 & $7.4 \%$ & 1 & $0.9 \%$ & 21 & $-4.8 \%$ & 35 & $0.7 \%$ & $-0.7 \%$ & 18 & $1.2 \%$ & 16 \\
\hline 14. & Coal mining & 21 & $3.0 \%$ & 19 & $-1.9 \%$ & 41 & $-6.1 \%$ & 39 & $-0.8 \%$ & $-1.9 \%$ & 20 & $-1.2 \%$ & 37 \\
\hline 15. & Mot veh \& access & $381-383$ & $3.7 \%$ & 8 & $-1.1 \%$ & 37 & $-0.6 \%$ & 20 & $-1.4 \%$ & $0.0 \%$ & 13 & $0.6 \%$ & 21 \\
\hline 16. & Wearing apparel & $313-315$ & $3.0 \%$ & 20 & $0.1 \%$ & 30 & $3.2 \%$ & 1 & $-1.5 \%$ & $2.0 \%$ & 3 & $1.2 \%$ & 17 \\
\hline 17. & Beverages & 305 & $3.2 \%$ & 17 & $1.5 \%$ & 14 & $-3.6 \%$ & 33 & $-1.9 \%$ & $-3.1 \%$ & 27 & $0.6 \%$ & 22 \\
\hline 18. & Furniture & 391 & $1.0 \%$ & 34 & $2.7 \%$ & 7 & $3.0 \%$ & 2 & $-2.1 \%$ & $0.4 \%$ & 10 & $2.4 \%$ & 5 \\
\hline 19. & Paper and products & 323 & $0.5 \%$ & 38 & $4.0 \%$ & 3 & $-0.2 \%$ & 17 & $-2.3 \%$ & $-1.7 \%$ & 19 & $1.7 \%$ & 12 \\
\hline 20. & Water supply & 42 & $0.8 \%$ & 37 & $0.8 \%$ & 23 & $-5.0 \%$ & 36 & $-2.6 \%$ & $-4.3 \%$ & 34 & $-0.5 \%$ & 34 \\
\hline 21. & Finance \& insurance & $81-82$ & $2.7 \%$ & 22 & $3.4 \%$ & 6 & $1.8 \%$ & 6 & $-2.7 \%$ & $1.0 \%$ & 9 & $3.2 \%$ & 3 \\
\hline 22. & Machinery & $356-359$ & $3.2 \%$ & 16 & $-1.9 \%$ & 42 & $-0.5 \%$ & 18 & $-3.0 \%$ & $0.0 \%$ & 12 & $-0.3 \%$ & 28 \\
\hline 23. & Agriculture & 1 & $-0.2 \%$ & 41 & $-0.9 \%$ & 36 & $-0.9 \%$ & 21 & $-3.1 \%$ & $-2.0 \%$ & 21 & $-1.0 \%$ & 36 \\
\hline 24. & Other mining & $22 / 24 / 25 / 29$ & $3.7 \%$ & 9 & $0.7 \%$ & 25 & $-7.2 \%$ & 43 & $-3.6 \%$ & $-3.7 \%$ & 30 & $-0.5 \%$ & 33 \\
\hline 25. & Food & $301-304$ & $3.1 \%$ & 18 & $1.2 \%$ & 17 & $-2.8 \%$ & 29 & $-3.6 \%$ & $-2.7 \%$ & 26 & $0.5 \%$ & 23 \\
\hline 26. & Other manufact & $392-393$ & $-0.6 \%$ & 42 & $4.5 \%$ & 2 & $2.7 \%$ & 5 & $-3.8 \%$ & $-0.2 \%$ & 15 & $2.4 \%$ & 4 \\
\hline 27. & Tobacco & 306 & $1.9 \%$ & 28 & $-0.4 \%$ & 33 & $-7.1 \%$ & 42 & $-4.6 \%$ & $-5.1 \%$ & 37 & $-1.7 \%$ & 41 \\
\hline 28. & Rubber products & 337 & $2.4 \%$ & 26 & $-0.1 \%$ & 32 & $-0.5 \%$ & 19 & $-4.8 \%$ & $-2.0 \%$ & 22 & $-0.4 \%$ & 31 \\
\hline 29. & Prof \& sci equipm & $374-376$ & $-1.5 \%$ & 44 & $3.9 \%$ & 4 & $1.4 \%$ & 8 & $-4.9 \%$ & $-2.5 \%$ & 24 & $1.7 \%$ & 10 \\
\hline 30. & Electrical mach & $361-366$ & $3.3 \%$ & 15 & $1.2 \%$ & 19 & $0.5 \%$ & 14 & $-5.0 \%$ & $-3.4 \%$ & 28 & $1.5 \%$ & 13 \\
\hline$\overline{31 .}$ & Basic nonferr met & 352 & $3.7 \%$ & 10 & $-0.8 \%$ & 35 & $-5.9 \%$ & 38 & $-5.2 \%$ & $-5.8 \%$ & 40 & $-0.8 \%$ & 35 \\
\hline 32. & Metal products & $353-355$ & $1.8 \%$ & 29 & $-1.8 \%$ & 40 & $-1.5 \%$ & 24 & $-5.7 \%$ & $-2.0 \%$ & 23 & $-0.4 \%$ & 30 \\
\hline 33. & Transport & $71-74$ & $3.5 \%$ & 13 & $-3.4 \%$ & 44 & $-6.2 \%$ & 40 & $-5.8 \%$ & $-4.6 \%$ & 36 & $-2.0 \%$ & 42 \\
\hline 34. & Petroleum products & $331-333$ & $5.1 \%$ & 5 & $0.5 \%$ & 28 & $-3.6 \%$ & 32 & $-6.9 \%$ & $-5.2 \%$ & 38 & $1.1 \%$ & 18 \\
\hline 35. & Cat \& accomm serv & 64 & $1.3 \%$ & 32 & $0.5 \%$ & 29 & $-2.1 \%$ & 26 & $-6.9 \%$ & $-3.6 \%$ & 29 & $0.0 \%$ & 25 \\
\hline 36. & Communication & 75 & $3.0 \%$ & 21 & $2.0 \%$ & 13 & $-2.3 \%$ & 27 & $-7.0 \%$ & $-3.8 \%$ & 31 & $1.0 \%$ & 19 \\
\hline 37. & Civil eng & $52-53$ & $0.3 \%$ & 39 & $0.9 \%$ & 22 & $1.3 \%$ & 9 & $-9.1 \%$ & $-4.2 \%$ & 33 & $-0.3 \%$ & 29 \\
\hline 38. & Textiles & $311-312$ & $0.9 \%$ & 36 & $-1.3 \%$ & 39 & $-7.7 \%$ & 44 & $-9.5 \%$ & $-4.4 \%$ & 35 & $-2.2 \%$ & 43 \\
\hline 39. & Glass and products & 341 & $-1.2 \%$ & 43 & $0.8 \%$ & 24 & $0.8 \%$ & 12 & $-9.7 \%$ & $-4.0 \%$ & 32 & $-0.2 \%$ & 27 \\
\hline 40. & Other trnsp equipm & $384-387$ & $1.5 \%$ & 30 & $-5.7 \%$ & 45 & $-10.7 \%$ & 45 & $-10.5 \%$ & $-7.6 \%$ & 43 & $-3.9 \%$ & 45 \\
\hline$\overline{41 .}$ & Construction & 51 & $-1.8 \%$ & 45 & $-1.2 \%$ & 38 & $-4.3 \%$ & 34 & $-10.8 \%$ & $-7.4 \%$ & 42 & $-1.6 \%$ & 40 \\
\hline 42. & Footwear & 317 & $1.0 \%$ & 35 & $1.1 \%$ & 20 & $-1.2 \%$ & 22 & $-11.4 \%$ & $-5.6 \%$ & 39 & $-0.4 \%$ & 32 \\
\hline 43. & Basic iron \& steel & 351 & $4.3 \%$ & 7 & $-3.3 \%$ & 43 & $-6.2 \%$ & 41 & $-11.7 \%$ & $-7.3 \%$ & 41 & $-2.2 \%$ & 44 \\
\hline 44. & Gold & 23 & $1.3 \%$ & 33 & $0.6 \%$ & 26 & $-3.3 \%$ & 30 & $-12.9 \%$ & $-7.8 \%$ & 45 & $-1.3 \%$ & 39 \\
\hline 45. & Non-met min & 342 & $0.3 \%$ & 40 & $-0.6 \%$ & 34 & $-3.5 \%$ & 31 & $-15.7 \%$ & $-7.7 \%$ & 44 & $-1.3 \%$ & 38 \\
\hline 46. & Total val add at fct cst & $1-9$ & $1.8 \%$ & & $0.2 \%$ & & $-1.6 \%$ & & $-2.6 \%$ & $-1.8 \%$ & & $0.1 \%$ & \\
\hline 47. & Tradables & $1-3$ & $1.4 \%$ & & $-0.1 \%$ & & $-1.8 \%$ & & $-4.1 \%$ & $-2.5 \%$ & & $-0.3 \%$ & \\
\hline 48. & Non-trade & 49 & $2.4 \%$ & & $0.5 \%$ & & $-1.4 \%$ & & $-0.8 \%$ & $-0.9 \%$ & & $0.5 \%$ & \\
\hline 49. & Mining & 2 & $2.1 \%$ & & $0.3 \%$ & & $-4.6 \%$ & & $-8.7 \%$ & $-5.9 \%$ & & $-1.1 \%$ & \\
\hline 50. & Manufact & 3 & $2.4 \%$ & & $0.3 \%$ & & $-1.2 \%$ & & $-3.0 \%$ & $-1.5 \%$ & & $0.5 \%$ & \\
\hline 51. & Light manf & $301-302,391$ & $2.4 \%$ & & $0.9 \%$ & & $-1.5 \%$ & & $-2.8 \%$ & $-1.2 \%$ & & $0.5 \%$ & \\
\hline 52. & Heavy manf & $323,331-355$ & $2.4 \%$ & & $-0.4 \%$ & & $-2.0 \%$ & & $-3.8 \%$ & $-2.5 \%$ & & $0.0 \%$ & \\
\hline 53. & Tech manf & $324-326,356-387,392$ & $2.4 \%$ & & $0.2 \%$ & & $0.2 \%$ & & $-2.3 \%$ & $-0.8 \%$ & & $1.0 \%$ & \\
\hline
\end{tabular}

Source: TIPS South African Standardised Industrial Data Base and own calculations 
The third component of the real wage growth decomposition is the wage share effect. If the wage share parameter, $\alpha$, is less than 1 , any positive effect on real wage growth emanating from the producer price inflation, $\hat{P_{p}}$, is appropriated by capital. The results are shown in Table A 8 .

For the economy as a whole we see in row 46 that the wage share effect has been slightly negative during the second half of the 1990s since labour has lost some of its share in value added. As a result the economy-wide increase in the producer price benefited capital rather than labour. However, some improvement has been recorded compared to the first half of the 1990s when the wage share effect was more negative. In the case of tradables, the wage share effect was positive during the second half of the 1990s, while that of non-tradables was negative. In the case of the former it has been light manufacturing where labour has managed to benefit from producer price increases, especially leather (row 3), food (row 4), beverages (5) and clothing (row 11) although they were to some degree off-set by losses in the textiles (row 43). During the same time, the mining sector as a whole recorded significant losses in the wage share effect, as opposed to significant gains during the 1980s (see row 49). 
Table A 8: The Wage Share Effect on Real Wage Growth

\begin{tabular}{|c|c|c|c|c|c|c|c|c|c|c|c|c|c|}
\hline \multirow[b]{2}{*}{$\overline{\mathrm{Nr}}$} & \multirow[b]{2}{*}{ Description } & \multirow[b]{2}{*}{ SIC } & \multicolumn{7}{|c|}{$(\alpha-1) \hat{P_{p}}$} & \multirow[b]{2}{*}{$\begin{array}{c}\text { full } 1990 \mathrm{~s} \\
8\end{array}$} & \multirow[b]{2}{*}{$\begin{array}{c}\text { rank } \\
9\end{array}$} & \multirow[b]{2}{*}{$\begin{array}{c}\text { full period } \\
10\end{array}$} & \multirow[b]{2}{*}{$\begin{array}{c}\text { rank } \\
11\end{array}$} \\
\hline & & & $\begin{array}{c}1970 \mathrm{~s} \\
1\end{array}$ & $\begin{array}{l}\text { rank } \\
2\end{array}$ & $\begin{array}{c}1980 \mathrm{~s} \\
3\end{array}$ & $\begin{array}{c}\text { rank } \\
4\end{array}$ & $\begin{array}{l}1^{\text {sthalf } 90 s} \\
5\end{array}$ & $\begin{array}{c}\text { rank } \\
6\end{array}$ & $\begin{array}{c}2^{\text {nd half }} \text { 90s } \\
7\end{array}$ & & & & \\
\hline $\begin{array}{l}1 . \\
2 .\end{array}$ & $\begin{array}{l}\text { Agriculture } \\
\text { Paper and products }\end{array}$ & $\begin{array}{l}1 \\
323\end{array}$ & $\begin{array}{l}0.2 \% \\
-1.1 \%\end{array}$ & $\begin{array}{l}11 \\
34\end{array}$ & $\begin{array}{l}-2.0 \% \\
-3.5 \%\end{array}$ & $\begin{array}{l}33 \\
42\end{array}$ & $\begin{array}{l}1.7 \% \\
-1.4 \%\end{array}$ & $\begin{array}{c}5 \\
26\end{array}$ & $\begin{array}{l}8.1 \% \\
7.0 \%\end{array}$ & $\begin{array}{l}1.5 \% \\
0.7 \%\end{array}$ & $\begin{array}{l}10 \\
13\end{array}$ & $\begin{array}{l}0.2 \% \\
-1.5 \%\end{array}$ & $\begin{array}{c}7 \\
39\end{array}$ \\
\hline 3. & Leather and products & 316 & $-0.5 \%$ & 25 & $-3.7 \%$ & 43 & $-3.0 \%$ & 35 & $5.7 \%$ & $4.6 \%$ & 4 & $-1.5 \%$ & 40 \\
\hline 4. & Food & $301-304$ & $-0.1 \%$ & 17 & $0.5 \%$ & 7 & $-0.6 \%$ & 20 & $5.5 \%$ & $1.1 \%$ & 11 & $0.1 \%$ & 9 \\
\hline 5. & Beverages & 305 & $0.9 \%$ & 4 & $-2.0 \%$ & 34 & $-5.9 \%$ & 43 & $5.3 \%$ & $-2.4 \%$ & 37 & $-1.2 \%$ & 35 \\
\hline $\begin{array}{l}6 . \\
7 .\end{array}$ & $\begin{array}{l}\text { Tobacco } \\
\text { TV \& comms equipm }\end{array}$ & $\begin{array}{l}306 \\
371-373\end{array}$ & $\begin{array}{l}4.9 \% \\
-0.9 \%\end{array}$ & $\begin{array}{c}1 \\
32\end{array}$ & $\begin{array}{l}0.4 \% \\
-1.0 \%\end{array}$ & $\begin{array}{c}9 \\
22\end{array}$ & $\begin{array}{l}-11.7 \% \\
2.0 \%\end{array}$ & $\begin{array}{c}45 \\
3\end{array}$ & $\begin{array}{l}4.2 \% \\
4.0 \%\end{array}$ & $\begin{array}{l}-7.3 \% \\
4.2 \%\end{array}$ & $\begin{array}{c}45 \\
6\end{array}$ & $\begin{array}{l}-0.5 \% \\
0.0 \%\end{array}$ & $\begin{array}{l}23 \\
11\end{array}$ \\
\hline 8. & Cat \& accomm serv & 64 & $3.4 \%$ & 2 & $-2.8 \%$ & 39 & $-2.2 \%$ & 33 & $3.6 \%$ & $-0.8 \%$ & 29 & $-1.4 \%$ & 37 \\
\hline 9. & Print, publ \& rec media & 324326 & $-0.3 \%$ & 22 & $-1.1 \%$ & 26 & $-1.8 \%$ & 29 & $3.2 \%$ & $-0.5 \%$ & 25 & $-0.7 \%$ & 30 \\
\hline 10. & Wood and products & $321-322$ & $-0.6 \%$ & 27 & $-1.0 \%$ & 23 & $-0.3 \%$ & 19 & $2.6 \%$ & $1.0 \%$ & 12 & $-0.7 \%$ & 29 \\
\hline $\begin{array}{l}11 . \\
12 .\end{array}$ & $\begin{array}{l}\text { Wearing apparel } \\
\text { Electricity }\end{array}$ & $\begin{array}{l}313-315 \\
41\end{array}$ & $\begin{array}{l}0.3 \% \\
-4.0 \%\end{array}$ & $\begin{array}{l}10 \\
43\end{array}$ & $\begin{array}{l}-1.0 \% \\
0.0 \%\end{array}$ & $\begin{array}{l}24 \\
15\end{array}$ & $\begin{array}{l}0.7 \% \\
-0.7 \%\end{array}$ & $\begin{array}{l}11 \\
22\end{array}$ & $\begin{array}{l}2.1 \% \\
1.9 \%\end{array}$ & $\begin{array}{l}2.0 \% \\
2.3 \%\end{array}$ & $\begin{array}{l}9 \\
8\end{array}$ & $\begin{array}{l}0.1 \% \\
0.0 \%\end{array}$ & $\begin{array}{c}8 \\
15\end{array}$ \\
\hline 13. & Furniture & 391 & $0.3 \%$ & 9 & $-1.1 \%$ & 27 & $4.9 \%$ & 2 & $1.8 \%$ & $4.5 \%$ & 5 & $0.1 \%$ & 10 \\
\hline 14. & Business services & 83-88 & $1.8 \%$ & 3 & $2.6 \%$ & 5 & $-1.8 \%$ & 28 & $1.3 \%$ & $0.0 \%$ & 19 & $0.4 \%$ & 6 \\
\hline 15. & Plastic products & 338 & $-0.2 \%$ & 19 & $0.1 \%$ & 13 & $-0.6 \%$ & 21 & $0.9 \%$ & $-0.1 \%$ & 20 & $-0.3 \%$ & 20 \\
\hline $\begin{array}{l}16 . \\
17 .\end{array}$ & $\begin{array}{l}\text { Electrical mach } \\
\text { Rubber products }\end{array}$ & $\begin{array}{l}361-366 \\
337\end{array}$ & $\begin{array}{l}0.1 \% \\
-0.1 \%\end{array}$ & $\begin{array}{l}13 \\
18\end{array}$ & $\begin{array}{l}0.1 \% \\
0.2 \%\end{array}$ & $\begin{array}{l}14 \\
12\end{array}$ & $\begin{array}{l}1.4 \% \\
0.3 \%\end{array}$ & $\begin{array}{c}6 \\
15\end{array}$ & $\begin{array}{l}0.7 \% \\
0.6 \%\end{array}$ & $\begin{array}{l}-0.1 \% \\
-0.2 \%\end{array}$ & $\begin{array}{l}21 \\
23\end{array}$ & $\begin{array}{l}0.0 \% \\
-0.1 \%\end{array}$ & $\begin{array}{l}14 \\
18\end{array}$ \\
\hline 18. & Trade & $61-63$ & $0.7 \%$ & 6 & $-0.4 \%$ & 20 & $-2.1 \%$ & 32 & $0.6 \%$ & $-0.6 \%$ & 27 & $-0.1 \%$ & 17 \\
\hline 19. & Soc serv: medical & 93 & $-0.8 \%$ & 31 & $3.2 \%$ & 2 & $-4.6 \%$ & 39 & $0.5 \%$ & $-1.2 \%$ & 31 & $0.7 \%$ & 5 \\
\hline 20. & Other chemicals & $335-336$ & $0.5 \%$ & 8 & $-0.1 \%$ & 17 & $-2.5 \%$ & 34 & $0.5 \%$ & $-1.4 \%$ & 34 & $-0.5 \%$ & 22 \\
\hline $\begin{array}{l}21 . \\
22 .\end{array}$ & $\begin{array}{l}\text { Machinery } \\
\text { Transport }\end{array}$ & $\begin{array}{l}356-359 \\
71-74\end{array}$ & $\begin{array}{l}0.7 \% \\
-1.7 \%\end{array}$ & $\begin{array}{c}5 \\
37\end{array}$ & $\begin{array}{l}-2.0 \% \\
-4.1 \%\end{array}$ & $\begin{array}{l}35 \\
44\end{array}$ & $\begin{array}{l}-0.1 \% \\
-1.2 \%\end{array}$ & $\begin{array}{l}17 \\
25\end{array}$ & $\begin{array}{l}0.3 \% \\
0.2 \%\end{array}$ & $\begin{array}{l}-0.1 \% \\
0.1 \%\end{array}$ & $\begin{array}{l}22 \\
16\end{array}$ & $\begin{array}{l}-0.6 \% \\
-1.4 \%\end{array}$ & $\begin{array}{l}25 \\
38\end{array}$ \\
\hline 23. & Other trnsp equipm & $384-387$ & $0.5 \%$ & 7 & $-0.3 \%$ & 18 & $-3.9 \%$ & 37 & $0.1 \%$ & $3.3 \%$ & 7 & $-0.1 \%$ & 16 \\
\hline 24. & Other producers & 98 & $0.1 \%$ & 12 & $0.0 \%$ & 16 & $0.0 \%$ & 16 & $0.1 \%$ & $0.1 \%$ & 17 & $0.0 \%$ & 13 \\
\hline 25. & Soc serv: other & 9496 & $-0.7 \%$ & 30 & $2.8 \%$ & 3 & $-4.8 \%$ & 40 & $0.1 \%$ & $-1.4 \%$ & 32 & $-0.2 \%$ & 19 \\
\hline $\begin{array}{l}26 . \\
27 .\end{array}$ & $\begin{array}{l}\text { Metal products } \\
\text { Basic chemicals }\end{array}$ & $\begin{array}{l}353-355 \\
334\end{array}$ & $\begin{array}{l}-0.1 \% \\
-0.4 \%\end{array}$ & $\begin{array}{l}16 \\
24\end{array}$ & $\begin{array}{l}-0.4 \% \\
-1.1 \%\end{array}$ & $\begin{array}{l}19 \\
25\end{array}$ & $\begin{array}{l}-0.3 \% \\
-0.9 \%\end{array}$ & $\begin{array}{l}18 \\
23\end{array}$ & $\begin{array}{l}0.0 \% \\
-0.1 \%\end{array}$ & $\begin{array}{l}-0.5 \% \\
-1.4 \%\end{array}$ & $\begin{array}{l}26 \\
33\end{array}$ & $\begin{array}{l}-0.6 \% \\
-0.4 \%\end{array}$ & $\begin{array}{l}28 \\
21\end{array}$ \\
\hline 28. & Mot veh \& access & $381-383$ & $-0.6 \%$ & 29 & $-4.2 \%$ & 45 & $-1.9 \%$ & 31 & $-0.2 \%$ & $0.3 \%$ & 15 & $-1.7 \%$ & 43 \\
\hline 29. & Other manufact & $392-393$ & $-2.4 \%$ & 41 & $-2.7 \%$ & 38 & $0.7 \%$ & 12 & $-0.9 \%$ & $-0.3 \%$ & 24 & $-1.3 \%$ & 36 \\
\hline 30. & Construction & 51 & $-0.6 \%$ & 28 & $0.4 \%$ & 10 & $-5.1 \%$ & 41 & $-1.0 \%$ & $-3.5 \%$ & 41 & $-1.0 \%$ & 33 \\
\hline $\begin{array}{l}31 . \\
32 .\end{array}$ & $\begin{array}{l}\text { Coal mining } \\
\text { Footwear }\end{array}$ & $\begin{array}{l}21 \\
317\end{array}$ & $\begin{array}{l}-6.4 \% \\
-1.0 \%\end{array}$ & $\begin{array}{l}45 \\
33\end{array}$ & $\begin{array}{l}1.6 \% \\
-1.7 \%\end{array}$ & $\begin{array}{c}6 \\
31\end{array}$ & $\begin{array}{l}-4.1 \% \\
1.8 \%\end{array}$ & $\begin{array}{c}38 \\
4\end{array}$ & $\begin{array}{l}-1.1 \% \\
-1.3 \%\end{array}$ & $\begin{array}{l}-2.0 \% \\
-5.7 \%\end{array}$ & $\begin{array}{l}35 \\
44\end{array}$ & $\begin{array}{l}0.0 \% \\
-0.6 \%\end{array}$ & $\begin{array}{l}12 \\
24\end{array}$ \\
\hline 33. & Finance \& insurance & 81-82 & $-1.5 \%$ & 35 & $-2.8 \%$ & 40 & $0.8 \%$ & 10 & $-1.4 \%$ & $-0.7 \%$ & 28 & $-0.8 \%$ & 31 \\
\hline 34. & Civil eng & $52-53$ & $-0.4 \%$ & 23 & $-1.2 \%$ & 28 & $-6.1 \%$ & 44 & $-1.4 \%$ & $-4.1 \%$ & 43 & $-1.6 \%$ & 41 \\
\hline 35. & Glass and products & 341 & $-1.7 \%$ & 38 & $-1.8 \%$ & 32 & $0.6 \%$ & 13 & $-1.5 \%$ & $0.5 \%$ & 14 & $-1.1 \%$ & 34 \\
\hline $\begin{array}{l}36 . \\
37 .\end{array}$ & $\begin{array}{l}\text { Communication } \\
\text { Other mining }\end{array}$ & $\begin{array}{l}75 \\
22 / 24 / 25 / 29\end{array}$ & $\begin{array}{l}-0.2 \% \\
-1.8 \%\end{array}$ & $\begin{array}{l}20 \\
39\end{array}$ & $\begin{array}{l}-3.3 \% \\
-1.7 \%\end{array}$ & $\begin{array}{l}41 \\
30\end{array}$ & $\begin{array}{l}-5.2 \% \\
0.6 \%\end{array}$ & $\begin{array}{l}42 \\
14\end{array}$ & $\begin{array}{l}-1.6 \% \\
-3.5 \%\end{array}$ & $\begin{array}{l}-3.3 \% \\
0.0 \%\end{array}$ & $\begin{array}{l}40 \\
18\end{array}$ & $\begin{array}{l}-2.5 \% \\
1.5 \%\end{array}$ & $\begin{array}{c}45 \\
3\end{array}$ \\
\hline 38. & Gold & 23 & $-3.6 \%$ & 42 & $9.5 \%$ & 1 & $7.3 \%$ & 1 & $-4.2 \%$ & $14.1 \%$ & 1 & $4.2 \%$ & 1 \\
\hline 39. & Basic iron \& steel & 351 & $-0.5 \%$ & 26 & $-2.3 \%$ & 36 & $-3.1 \%$ & 36 & $-5.8 \%$ & $-3.2 \%$ & 39 & $-1.7 \%$ & 42 \\
\hline 40. & Water supply & 42 & $-6.3 \%$ & 44 & $0.4 \%$ & 8 & $0.9 \%$ & 9 & $-8.0 \%$ & $-2.2 \%$ & 36 & $2.1 \%$ & 2 \\
\hline $\begin{array}{l}4 . \\
42 .\end{array}$ & $\begin{array}{l}\text { Petroleum products } \\
\text { Basic nonferr met }\end{array}$ & $\begin{array}{l}331-333 \\
352\end{array}$ & $\begin{array}{l}-1.8 \% \\
-1.6 \%\end{array}$ & $\begin{array}{l}40 \\
36\end{array}$ & $\begin{array}{l}2.6 \% \\
-2.4 \%\end{array}$ & $\begin{array}{c}4 \\
37\end{array}$ & $\begin{array}{l}0.9 \% \\
-1.6 \%\end{array}$ & $\begin{array}{c}8 \\
27\end{array}$ & $\begin{array}{l}-8.3 \% \\
-9.6 \%\end{array}$ & $\begin{array}{l}-0.9 \% \\
-3.7 \%\end{array}$ & $\begin{array}{l}30 \\
42\end{array}$ & $\begin{array}{l}-0.6 \% \\
-2.3 \%\end{array}$ & $\begin{array}{l}26 \\
44\end{array}$ \\
\hline 43. & Textiles & $311-312$ & $0.0 \%$ & 14 & $-0.6 \%$ & 21 & $1.0 \%$ & 7 & $-15.1 \%$ & $8.2 \%$ & 3 & $0.7 \%$ & 4 \\
\hline 44. & Prof \& sci equipm & $374-376$ & $0.0 \%$ & 15 & $-1.5 \%$ & 29 & $-1.0 \%$ & 24 & $-17.0 \%$ & $13.0 \%$ & 2 & $-0.6 \%$ & 27 \\
\hline 45. & Non-met min & 342 & $-0.3 \%$ & 21 & $0.2 \%$ & 11 & $-1.8 \%$ & 30 & $-57.7 \%$ & $-3.1 \%$ & 38 & $-0.9 \%$ & 32 \\
\hline $\begin{array}{l}46 . \\
47 .\end{array}$ & $\begin{array}{l}\text { Total val add at fct cst } \\
\text { Tradables }\end{array}$ & $\begin{array}{l}1-9 \\
1-3\end{array}$ & $\begin{array}{l}-1.1 \% \\
-1.4 \%\end{array}$ & & $\begin{array}{l}-0.7 \% \\
0.1 \%\end{array}$ & & $\begin{array}{l}-1.6 \% \\
-0.8 \%\end{array}$ & & $\begin{array}{c}-0.1 \% \\
0.9 \%\end{array}$ & $\begin{array}{l}-0.8 \% \\
-0.3 \%\end{array}$ & & $\begin{array}{l}-0.5 \% \\
0.1 \%\end{array}$ & \\
\hline 48. & Non-trade & 49 & $-0.5 \%$ & & $-1.4 \%$ & & $-2.1 \%$ & & $-0.4 \%$ & $-1.0 \%$ & & $-0.8 \%$ & \\
\hline 49. & Mining & 2 & $-3.4 \%$ & & $4.5 \%$ & & $-0.8 \%$ & & $-2.2 \%$ & $-0.8 \%$ & & $2.2 \%$ & \\
\hline 50. & Manufact & 3 & $-0.3 \%$ & & $-1.5 \%$ & & $-0.9 \%$ & & $0.9 \%$ & $-0.4 \%$ & & $-0.9 \%$ & \\
\hline 51. & Light manf & $301-302,391$ & $-0.1 \%$ & & $-0.7 \%$ & & $-0.8 \%$ & & $3.1 \%$ & $0.7 \%$ & & $-0.3 \%$ & \\
\hline 52. & Heavy manf & $323,331-355$ & $-0.5 \%$ & & $-1.2 \%$ & & $-1.4 \%$ & & $-0.4 \%$ & $-1.4 \%$ & & $-1.2 \%$ & \\
\hline 53. & Tech manf & $324-326,356-387,392$ & $-0.1 \%$ & & $-2.7 \%$ & & $-0.3 \%$ & & $0.6 \%$ & $-0.1 \%$ & & $-1.0 \%$ & \\
\hline
\end{tabular}

Source: TIPS South African Standardised Industrial Data Base and own calculations 
In terms of the tradable - non-tradable distinction, it is perhaps interesting to note that nontradable sectors have recorded onsistently lower since the 1980s, or more negative wage share effects. The reason is that the producer price inflation on non-tradables has consistently been higher than tradables (see

Table A 3), while the technology parameter has consistently been in favour of capital (see Table A $5)$.

The final component of the real wage growth decomposition is the domestic real exchange rate. If consumer price inflation is higher than producer price inflation, real wage growth is eroded. In row 46 it can be seen that on average, for all sectors, the domestic real exchange rate has had a neutral impact on real wage growth during the second half of the 1990s, while it was also flat during the 1980s but positive during the 1970s and the first half of the 1990s. 
Table A 9: The Domestic Real Exchange Rate

\begin{tabular}{|c|c|c|c|c|c|c|c|c|c|c|c|c|c|}
\hline & & & & & & & $\hat{P_{p}}-\hat{P_{c}}$ & & & & & & \\
\hline \multirow[t]{2}{*}{$\mathrm{Nr}$} & Description & SIC & 1970s & rank & $1980 \mathrm{~s}$ & rank & $1^{\text {sthalf } 90 s}$ & rank & $2^{\text {nd half } 90 \mathrm{~s}}$ & full 1990s & rank & full period & rank \\
\hline & & & 1 & 2 & 3 & 4 & 5 & 6 & 7 & 8 & 9 & 10 & 11 \\
\hline 1. & Water supply & 42 & $4.0 \%$ & 8 & $0.0 \%$ & 28 & $-3.6 \%$ & 42 & $8.1 \%$ & $1.9 \%$ & 8 & $-0.2 \%$ & 37 \\
\hline 2. & Petroleum products & $331-333$ & $9.3 \%$ & 3 & $-4.3 \%$ & 45 & $-3.3 \%$ & 41 & $6.4 \%$ & $1.4 \%$ & 13 & $1.4 \%$ & 13 \\
\hline 3. & Tobacco & 306 & $-3.4 \%$ & 43 & $-2.3 \%$ & 41 & $5.9 \%$ & 4 & $5.9 \%$ & $6.2 \%$ & 1 & $0.5 \%$ & 23 \\
\hline 4. & Other producers & 98 & $-0.6 \%$ & 29 & $1.1 \%$ & 15 & $1.4 \%$ & 14 & $5.3 \%$ & $3.6 \%$ & 5 & $1.4 \%$ & 14 \\
\hline 5. & Other mining & $22 / 24 / 25 / 29$ & $8.0 \%$ & 4 & $0.6 \%$ & 20 & $-2.2 \%$ & 39 & $5.2 \%$ & $1.3 \%$ & 14 & $-0.4 \%$ & 38 \\
\hline 6. & Soc serv: medical & 93 & $-1.1 \%$ & 35 & $0.4 \%$ & 23 & $9.1 \%$ & 2 & $4.3 \%$ & $5.2 \%$ & 2 & $1.9 \%$ & 4 \\
\hline 7. & Soc serv: other & 9496 & $-1.3 \%$ & 36 & $-0.3 \%$ & 32 & $9.1 \%$ & 1 & $4.1 \%$ & $5.0 \%$ & 3 & $1.5 \%$ & 12 \\
\hline 8. & Business services & $83-88$ & $-1.5 \%$ & 37 & $0.4 \%$ & 24 & $3.7 \%$ & 7 & $3.7 \%$ & $4.1 \%$ & 4 & $1.7 \%$ & 9 \\
\hline 9. & Furniture & 391 & $-4.0 \%$ & 45 & $-1.7 \%$ & 39 & $-0.7 \%$ & 26 & $2.6 \%$ & $0.0 \%$ & 21 & $-0.4 \%$ & 39 \\
\hline 10. & Print, publ \& rec media & 324326 & $0.1 \%$ & 23 & $1.5 \%$ & 9 & $1.1 \%$ & 18 & $2.6 \%$ & $1.8 \%$ & 9 & $1.7 \%$ & 8 \\
\hline 11. & Beverages & 305 & $-2.8 \%$ & 40 & $-1.3 \%$ & 37 & $2.9 \%$ & 11 & $2.3 \%$ & $1.6 \%$ & 11 & $-0.2 \%$ & 35 \\
\hline 12. & Finance \& insurance & 81-82 & $-0.9 \%$ & 33 & $1.9 \%$ & 6 & $3.6 \%$ & 8 & $1.5 \%$ & $1.1 \%$ & 16 & $1.6 \%$ & 10 \\
\hline 13. & Non-met min & 342 & $1.8 \%$ & 14 & $0.6 \%$ & 21 & $0.4 \%$ & 21 & $0.7 \%$ & $0.1 \%$ & 19 & $1.6 \%$ & 11 \\
\hline 14. & Prof \& sci equipm & 374376 & $-2.1 \%$ & 39 & $-0.1 \%$ & 29 & $7.2 \%$ & 3 & $0.6 \%$ & $2.8 \%$ & 6 & $0.5 \%$ & 24 \\
\hline 15. & Paper and products & 323 & $0.3 \%$ & 21 & $2.7 \%$ & 4 & $1.6 \%$ & 13 & $0.4 \%$ & $1.2 \%$ & 15 & $2.0 \%$ & 3 \\
\hline 16. & Food & $301-304$ & $0.5 \%$ & 20 & $-0.9 \%$ & 36 & $1.4 \%$ & 15 & $0.4 \%$ & $0.7 \%$ & 17 & $0.6 \%$ & 22 \\
\hline 17. & Coal mining & 21 & $18.2 \%$ & 2 & $-3.4 \%$ & 44 & $-2.2 \%$ & 38 & $0.3 \%$ & $0.5 \%$ & 18 & $1.8 \%$ & 5 \\
\hline 18. & Other chemicals & $335-336$ & $1.0 \%$ & 15 & $0.5 \%$ & 22 & $-1.9 \%$ & 33 & $0.2 \%$ & $-1.2 \%$ & 29 & $0.7 \%$ & 21 \\
\hline 19. & Plastic products & 338 & $4.3 \%$ & 7 & $-1.6 \%$ & 38 & $-4.3 \%$ & 44 & $0.1 \%$ & $-1.2 \%$ & 28 & $0.2 \%$ & 32 \\
\hline 20. & Cat \& accomm serv & 64 & $-0.5 \%$ & 28 & $2.3 \%$ & 5 & $3.5 \%$ & 9 & $0.0 \%$ & $2.2 \%$ & 7 & $2.0 \%$ & 2 \\
\hline 21. & Civil eng & $52-53$ & $0.7 \%$ & 18 & $0.7 \%$ & 18 & $4.6 \%$ & 5 & $-0.3 \%$ & $1.7 \%$ & 10 & $1.7 \%$ & 7 \\
\hline 22. & Construction & 51 & $-0.2 \%$ & 25 & $1.2 \%$ & 12 & $4.4 \%$ & 6 & $-0.4 \%$ & $1.6 \%$ & 12 & $1.8 \%$ & 6 \\
\hline 23. & Wearing apparel & $313-315$ & $-3.6 \%$ & 44 & $-0.7 \%$ & 35 & $-2.1 \%$ & 37 & $-0.8 \%$ & $-1.8 \%$ & 37 & $-1.2 \%$ & 44 \\
\hline 24. & Trade & $61-63$ & $0.2 \%$ & 22 & $1.3 \%$ & 11 & $2.2 \%$ & 12 & $-0.9 \%$ & $0.1 \%$ & 20 & $1.3 \%$ & 15 \\
\hline 25. & Basic non-ferr met & 352 & $0.8 \%$ & 16 & $1.6 \%$ & 8 & $-0.8 \%$ & 27 & $-1.1 \%$ & $-1.4 \%$ & 34 & $0.1 \%$ & 34 \\
\hline 26. & Wood and products & $321-322$ & $-0.4 \%$ & 27 & $1.3 \%$ & 10 & $-1.4 \%$ & 31 & $-1.1 \%$ & $-0.8 \%$ & 22 & $1.3 \%$ & 17 \\
\hline 27. & Electrical mach & $361-366$ & $-3.2 \%$ & 42 & $-0.5 \%$ & 34 & $-2.1 \%$ & 35 & $-1.2 \%$ & $-2.4 \%$ & 41 & $-0.9 \%$ & 43 \\
\hline 28. & Transport & $71-74$ & $-0.3 \%$ & 26 & $0.4 \%$ & 25 & $-0.9 \%$ & 28 & $-1.3 \%$ & $-1.1 \%$ & 27 & $-0.2 \%$ & 36 \\
\hline 29. & Leather and products & 316 & $0.8 \%$ & 17 & $3.2 \%$ & 3 & $1.3 \%$ & 16 & $-1.4 \%$ & $-1.0 \%$ & 26 & $0.2 \%$ & 30 \\
\hline 30. & Footwear & 317 & $1.9 \%$ & 13 & $-0.2 \%$ & 31 & $-0.9 \%$ & 29 & $-1.4 \%$ & $-1.3 \%$ & 32 & $0.5 \%$ & 25 \\
\hline 31. & Rubber products & 337 & $3.3 \%$ & 9 & $-2.0 \%$ & 40 & $-1.4 \%$ & 30 & $-1.6 \%$ & $-1.9 \%$ & 38 & $0.1 \%$ & 33 \\
\hline 32. & Mot veh \& access & $381-383$ & $-1.1 \%$ & 34 & $5.6 \%$ & 1 & $1.3 \%$ & 17 & $-1.7 \%$ & $-0.9 \%$ & 25 & $2.5 \%$ & 1 \\
\hline 33. & Basic iron \& steel & 351 & $4.7 \%$ & 6 & $-0.1 \%$ & 30 & $-0.1 \%$ & 24 & $-1.9 \%$ & $-0.8 \%$ & 23 & $1.2 \%$ & 18 \\
\hline 34. & Gold & 23 & $19.9 \%$ & 1 & $-3.1 \%$ & 43 & $-2.1 \%$ & 36 & $-1.9 \%$ & $-0.9 \%$ & 24 & $0.8 \%$ & 20 \\
\hline 35. & Textiles & $311-312$ & $-2.0 \%$ & 38 & $1.2 \%$ & 14 & $-3.7 \%$ & 43 & $-2.1 \%$ & $-2.6 \%$ & 42 & $-0.7 \%$ & 42 \\
\hline 36. & Other manufact & $392-393$ & $0.0 \%$ & 24 & $0.9 \%$ & 17 & $-0.1 \%$ & 23 & $-2.2 \%$ & $-1.4 \%$ & 36 & $0.5 \%$ & 27 \\
\hline 37. & TV \& comms equipm & $371-373$ & $-3.1 \%$ & 41 & $0.0 \%$ & 27 & $0.1 \%$ & 22 & $-2.3 \%$ & $-1.4 \%$ & 33 & $-0.5 \%$ & 40 \\
\hline 38. & Basic chemicals & 334 & $0.6 \%$ & 19 & $0.7 \%$ & 19 & $-2.0 \%$ & 34 & $-2.9 \%$ & $-2.0 \%$ & 39 & $0.5 \%$ & 26 \\
\hline 39. & Glass and products & 341 & $2.0 \%$ & 11 & $1.0 \%$ & 16 & $-1.8 \%$ & 32 & $-2.9 \%$ & $-3.2 \%$ & 43 & $1.1 \%$ & 19 \\
\hline 40. & Metal products & $353-355$ & $2.7 \%$ & 10 & $0.3 \%$ & 26 & $0.8 \%$ & 20 & $-3.2 \%$ & $-1.3 \%$ & 31 & $1.3 \%$ & 16 \\
\hline 41. & Communication & 75 & $-0.7 \%$ & 30 & $1.6 \%$ & 7 & $1.0 \%$ & 19 & $-3.3 \%$ & $-1.4 \%$ & 35 & $0.3 \%$ & 28 \\
\hline 42. & Machinery & $356-359$ & $1.9 \%$ & 12 & $-0.3 \%$ & 33 & $-0.3 \%$ & 25 & $-3.7 \%$ & $-2.3 \%$ & 40 & $0.3 \%$ & 29 \\
\hline 43. & Agriculture & 1 & $-0.9 \%$ & 32 & $-2.7 \%$ & 42 & $3.5 \%$ & 10 & $-5.1 \%$ & $-1.2 \%$ & 30 & $-1.8 \%$ & 45 \\
\hline 44. & Electricity & 41 & $5.1 \%$ & 5 & $1.2 \%$ & 13 & $-2.5 \%$ & 40 & $-5.4 \%$ & $-4.5 \%$ & 44 & $-0.6 \%$ & 41 \\
\hline 45. & Other trnsp equipm & 384387 & $-0.7 \%$ & 31 & $4.2 \%$ & 2 & $-4.6 \%$ & 45 & $-5.4 \%$ & $-5.7 \%$ & 45 & $0.2 \%$ & 31 \\
\hline 46. & Total val add at fct cst & $1-9$ & $2.5 \%$ & & $0.0 \%$ & & $1.2 \%$ & & $0.0 \%$ & $0.4 \%$ & & $0.8 \%$ & \\
\hline 47. & Tradables & $1-3$ & $5.1 \%$ & & $-1.1 \%$ & & $-0.2 \%$ & & $-0.9 \%$ & $-0.6 \%$ & & $0.3 \%$ & \\
\hline 48. & Non-trade & 49 & $0.1 \%$ & & $1.0 \%$ & & $2.3 \%$ & & $0.5 \%$ & $1.0 \%$ & & $1.2 \%$ & \\
\hline 49. & Mining & 2 & $16.7 \%$ & & $-2.8 \%$ & & $-2.3 \%$ & & $1.0 \%$ & $0.0 \%$ & & $0.7 \%$ & \\
\hline 50. & Manufact & 3 & $0.8 \%$ & & $0.4 \%$ & & $-0.2 \%$ & & $-0.7 \%$ & $-0.7 \%$ & & $0.8 \%$ & \\
\hline 51. & Light manf & 301-302, 391 & $-0.9 \%$ & & $-0.7 \%$ & & $0.1 \%$ & & $0.5 \%$ & $0.0 \%$ & & $0.1 \%$ & \\
\hline 52. & Heavy manf & $323,331-355$ & $2.8 \%$ & & $0.2 \%$ & & $-0.7 \%$ & & $-0.7 \%$ & $-0.7 \%$ & & $1.3 \%$ & \\
\hline 53. & Tech manf & $324-326,356-387,392$ & $-0.1 \%$ & & $1.6 \%$ & & $0.0 \%$ & & $-1.6 \%$ & $-1.3 \%$ & & $0.8 \%$ & \\
\hline
\end{tabular}

Source: TIPS South African Standardised Industrial Data Base and own calculations 
The weighted average domestic real exchange rate of tradables has been negative during the second half of 1990s, while it was positive for non-tradables. In terms of manufacturing the domestic real exchange rate has worked against growth in real wages, mainly due to heavy and technology intensive industries. The contribution by the domestic real exchange rate to real wage growth in mining was positive, after being negative during the earlier part of the 1990s and the 1980s; this and the services sector (see row 47) have, from this point of view, been better off. All other broad manufacturing clusters have experienced a negative domestic real exchange rate effect, except light manufacturing. The impact on the latter is expected, as light manufacturing probably has a relatively large weight in the consumer price inflation. With regard to mining, the positive impact of the domestic real exchange rate in the coal mining sector is more than outweighed by the negative impact of gold and other mining.

Since the decomposition method is additive in nature it is possible to sum the two price components into a single price effect as suggested by equation 6 above. In row 46 it can be seen that, on average, the 'price-effect' on real wage growth has been negative during the 1980s and 1990s after being positive during the 1970s. However, the trend has become less negative since the 1980s with an almost flat price effect during the second half of the 1990s which suggests that the producer price increases appropriated by labour have been more or less on par with the consumer price increases.

In the next two rows (47 and 48) it can be seen that throughout the whole period workers in the non-tradable industries have been better off than workers in the tradables industries, i.e., the price effect has been more negative. Within manufacturing, the picture is more mixed but at least during the second half of the 1990s, the price effect in light manufacturing was positive compared to negative effects recorded for the other manufacturing industries. These include industries such as beverages (row 2) and food (row 4). 
Table A 10: The Price Effect

\begin{tabular}{|c|c|c|c|c|c|c|c|c|c|c|c|c|c|}
\hline$\overline{\mathrm{Nr}}$ & Description & $\overline{S I C}$ & $\begin{array}{c}1970 \mathrm{~s} \\
1\end{array}$ & $\begin{array}{c}\text { rank } \\
2\end{array}$ & $\begin{array}{c}1980 \mathrm{~s} \\
3\end{array}$ & $\begin{array}{c}\text { rank } \\
4\end{array}$ & $\begin{array}{l}1^{\text {sh half } 90 \mathrm{~s}} \\
5\end{array}$ & $\begin{array}{c}\text { rank } \\
6\end{array}$ & $\begin{array}{c}2^{\text {nd }} \text { half } 90 \mathrm{~s} \\
7\end{array}$ & $\begin{array}{c}\text { full } 1990 \mathrm{~s} \\
8\end{array}$ & $\begin{array}{c}\text { rank } \\
9\end{array}$ & $\begin{array}{c}\text { full period } \\
10\end{array}$ & $\begin{array}{c}\text { rank } \\
11\end{array}$ \\
\hline$\overline{1 .}$ & Tobacco & 306 & $1.5 \%$ & 11 & $-1.9 \%$ & 38 & $-5.8 \%$ & 43 & $10.1 \%$ & $-1.1 \%$ & 26 & $0.0 \%$ & 26 \\
\hline 2. & Beverages & 305 & $-1.9 \%$ & 33 & $-3.2 \%$ & 43 & $-3.0 \%$ & 37 & $7.6 \%$ & $-0.8 \%$ & 24 & $-1.4 \%$ & 41 \\
\hline 3. & Paper and products & 323 & $-0.9 \%$ & 29 & $-0.8 \%$ & 24 & $0.2 \%$ & 16 & $7.4 \%$ & $1.9 \%$ & 11 & $0.5 \%$ & 20 \\
\hline 4. & Food & $301-304$ & $0.3 \%$ & 17 & $-0.4 \%$ & 18 & $0.8 \%$ & 13 & $5.9 \%$ & $1.7 \%$ & 12 & $0.7 \%$ & 16 \\
\hline 5. & Print, publ \& rec media & 324326 & $-0.3 \%$ & 24 & $0.4 \%$ & 13 & $-0.7 \%$ & 22 & $5.8 \%$ & $1.3 \%$ & 15 & $1.0 \%$ & 10 \\
\hline$\overline{6 .}$ & Other producers & 98 & $-0.5 \%$ & 25 & $1.1 \%$ & 9 & $1.4 \%$ & 10 & $5.4 \%$ & $3.7 \%$ & 7 & $1.4 \%$ & 6 \\
\hline 7. & Business services & $83-88$ & $0.3 \%$ & 19 & $3.0 \%$ & 4 & $1.9 \%$ & 9 & $5.1 \%$ & $4.1 \%$ & 5 & $2.1 \%$ & 3 \\
\hline 8. & Soc serv: medical & 93 & $-1.9 \%$ & 34 & $3.6 \%$ & 3 & $4.5 \%$ & 4 & $4.9 \%$ & $4.0 \%$ & 6 & $2.6 \%$ & 2 \\
\hline 9. & Furniture & 391 & $-3.7 \%$ & 44 & $-2.9 \%$ & 42 & $4.2 \%$ & 7 & $4.4 \%$ & $4.5 \%$ & 4 & $-0.3 \%$ & 33 \\
\hline 10. & Leather and products & 316 & $0.3 \%$ & 20 & $-0.5 \%$ & 22 & $-1.7 \%$ & 29 & $4.3 \%$ & $3.6 \%$ & 9 & $-1.3 \%$ & 40 \\
\hline$\overline{11 .}$ & Soc serv: other & 9496 & $-2.0 \%$ & 37 & $2.5 \%$ & 5 & $4.3 \%$ & 6 & $4.1 \%$ & $3.6 \%$ & 8 & $1.2 \%$ & 7 \\
\hline 12. & Cat $\&$ accomm serv & 64 & $2.9 \%$ & 8 & $-0.5 \%$ & 21 & $1.3 \%$ & 11 & $3.5 \%$ & $1.4 \%$ & 13 & $0.6 \%$ & 18 \\
\hline 13. & Agriculture & 1 & $-0.7 \%$ & 26 & $-4.6 \%$ & 45 & $5.2 \%$ & 3 & $3.0 \%$ & $0.3 \%$ & 18 & $-1.6 \%$ & 42 \\
\hline 14. & TV \& comms equipm & $371-373$ & $-4.0 \%$ & 45 & $-1.0 \%$ & 28 & $2.1 \%$ & 8 & $1.8 \%$ & $2.8 \%$ & 10 & $-0.4 \%$ & 34 \\
\hline 15. & Other mining & $22 / 24 / 25 / 29$ & $6.2 \%$ & 4 & $-1.0 \%$ & 29 & $-1.7 \%$ & 28 & $1.7 \%$ & $1.3 \%$ & 14 & $1.1 \%$ & 9 \\
\hline 16. & Wood and products & $321-322$ & $-1.0 \%$ & 31 & $0.4 \%$ & 15 & $-1.8 \%$ & 30 & $1.5 \%$ & $0.2 \%$ & 19 & $0.6 \%$ & 19 \\
\hline 17. & Wearing apparel & $313-315$ & $-3.3 \%$ & 43 & $-1.7 \%$ & 32 & $-1.4 \%$ & 25 & $1.4 \%$ & $0.2 \%$ & 20 & $-1.1 \%$ & 39 \\
\hline 18. & Plastic products & 338 & $4.1 \%$ & 6 & $-1.5 \%$ & 30 & $-5.0 \%$ & 42 & $1.1 \%$ & $-1.3 \%$ & 27 & $-0.1 \%$ & 31 \\
\hline 19. & Other chemicals & $335-336$ & $1.4 \%$ & 13 & $0.4 \%$ & 14 & $-4.3 \%$ & 41 & $0.7 \%$ & $-2.6 \%$ & 38 & $0.2 \%$ & 21 \\
\hline 20. & Finance \& insurance & $81-82$ & $-2.4 \%$ & 41 & $-0.9 \%$ & 27 & $4.4 \%$ & 5 & $0.1 \%$ & $0.4 \%$ & 17 & $0.8 \%$ & 14 \\
\hline$\overline{21 .}$ & Water supply & 42 & $-2.2 \%$ & 39 & $0.3 \%$ & 16 & $-2.7 \%$ & 35 & $0.1 \%$ & $-0.3 \%$ & 21 & $1.8 \%$ & 5 \\
\hline 22. & Trade & $61-63$ & $1.0 \%$ & 15 & $0.9 \%$ & 10 & $0.1 \%$ & 17 & $-0.4 \%$ & $-0.5 \%$ & 22 & $1.2 \%$ & 8 \\
\hline 23. & Electrical mach & $361-366$ & $-3.1 \%$ & 42 & $-0.5 \%$ & 20 & $-0.6 \%$ & 20 & $-0.4 \%$ & $-2.5 \%$ & 37 & $-0.9 \%$ & 38 \\
\hline 24. & Coal mining & 21 & $11.8 \%$ & 2 & $-1.7 \%$ & 35 & $-6.3 \%$ & 44 & $-0.8 \%$ & $-1.6 \%$ & 28 & $1.9 \%$ & 4 \\
\hline 25. & Rubber products & 337 & $3.2 \%$ & 7 & $-1.8 \%$ & 37 & $-1.1 \%$ & 23 & $-1.0 \%$ & $-2.2 \%$ & 32 & $-0.1 \%$ & 29 \\
\hline 26. & Transport & $71-74$ & $-1.9 \%$ & 35 & $-3.7 \%$ & 44 & $-2.1 \%$ & 31 & $-1.2 \%$ & $-1.0 \%$ & 25 & $-1.6 \%$ & 43 \\
\hline 27. & Construction & 51 & $-0.8 \%$ & 28 & $1.6 \%$ & 6 & $-0.7 \%$ & 21 & $-1.4 \%$ & $-1.9 \%$ & 31 & $0.8 \%$ & 12 \\
\hline 28. & Civil eng & $52-53$ & $0.3 \%$ & 18 & $-0.5 \%$ & 23 & $-1.6 \%$ & 27 & $-1.7 \%$ & $-2.4 \%$ & 36 & $0.1 \%$ & 24 \\
\hline 29. & Mot veh \& access & $381-383$ & $-1.6 \%$ & 32 & $1.4 \%$ & 7 & $-0.6 \%$ & 19 & $-1.8 \%$ & $-0.7 \%$ & 23 & $0.8 \%$ & 13 \\
\hline 30. & Petroleum products & $331-333$ & $7.5 \%$ & 3 & $-1.7 \%$ & 34 & $-2.4 \%$ & 33 & $-1.9 \%$ & $0.5 \%$ & 16 & $0.9 \%$ & 11 \\
\hline$\overline{31 .}$ & Footwear & 317 & $0.9 \%$ & 16 & $-2.0 \%$ & 39 & $0.9 \%$ & 12 & $-2.7 \%$ & $-7.0 \%$ & 45 & $-0.1 \%$ & 28 \\
\hline 32. & Basic chemicals & 334 & $0.1 \%$ & 22 & $-0.5 \%$ & 19 & $-2.9 \%$ & 36 & $-3.0 \%$ & $-3.4 \%$ & 41 & $0.1 \%$ & 22 \\
\hline 33. & Other manufact & 392-393 & $-2.4 \%$ & 40 & $-1.8 \%$ & 36 & $0.6 \%$ & 14 & $-3.1 \%$ & $-1.7 \%$ & 29 & $-0.8 \%$ & 37 \\
\hline 34. & Metal products & $353-355$ & $2.6 \%$ & 10 & $-0.1 \%$ & 17 & $0.5 \%$ & 15 & $-3.2 \%$ & $-1.8 \%$ & 30 & $0.7 \%$ & 17 \\
\hline 35. & Machinery & $356-359$ & $2.7 \%$ & 9 & $-2.3 \%$ & 40 & $-0.4 \%$ & 18 & $-3.4 \%$ & $-2.3 \%$ & 34 & $-0.3 \%$ & 32 \\
\hline 36. & Electricity & 41 & $1.1 \%$ & 14 & $1.2 \%$ & 8 & $-3.2 \%$ & 38 & $-3.4 \%$ & $-2.2 \%$ & 33 & $-0.7 \%$ & 36 \\
\hline 37. & Glass and products & 341 & $0.2 \%$ & 21 & $-0.8 \%$ & 26 & $-1.1 \%$ & 24 & $-4.4 \%$ & $-2.7 \%$ & 39 & $0.0 \%$ & 25 \\
\hline 38. & Communication & 75 & $-0.9 \%$ & 30 & $-1.7 \%$ & 33 & $-4.2 \%$ & 40 & $-4.9 \%$ & $-4.6 \%$ & 43 & $-2.2 \%$ & 44 \\
\hline 39. & Other trnsp equipm & 384387 & $-0.2 \%$ & 23 & $4.0 \%$ & 2 & $-8.5 \%$ & 45 & $-5.3 \%$ & $-2.4 \%$ & 35 & $0.1 \%$ & 23 \\
\hline 40. & Gold & 23 & $16.3 \%$ & 1 & $6.3 \%$ & 1 & $5.2 \%$ & 2 & $-6.2 \%$ & $13.3 \%$ & 2 & $5.0 \%$ & 1 \\
\hline$\overline{41 .}$ & Basic iron \& steel & 351 & $4.2 \%$ & 5 & $-2.4 \%$ & 41 & $-3.3 \%$ & 39 & $-7.7 \%$ & $-4.0 \%$ & 42 & $-0.5 \%$ & 35 \\
\hline 42. & Basic nonferr met & 352 & $-0.7 \%$ & 27 & $-0.8 \%$ & 25 & $-2.3 \%$ & 32 & $-10.7 \%$ & $-5.1 \%$ & 44 & $-2.2 \%$ & 45 \\
\hline 43. & Prof \& sci equipm & $374-376$ & $-2.1 \%$ & 38 & $-1.5 \%$ & 31 & $6.2 \%$ & 1 & $-16.4 \%$ & $15.9 \%$ & 1 & $-0.1 \%$ & 30 \\
\hline 44. & Textiles & $311-312$ & $-2.0 \%$ & 36 & $0.6 \%$ & 12 & $-2.6 \%$ & 34 & $-17.2 \%$ & $5.6 \%$ & 3 & $0.0 \%$ & 27 \\
\hline 45. & Non-met min & 342 & $1.5 \%$ & 12 & $0.8 \%$ & 11 & $-1.4 \%$ & 26 & $-57.0 \%$ & $-3.0 \%$ & 40 & $0.7 \%$ & 15 \\
\hline 46. & Total val add at fct cst & $1-9$ & $1.4 \%$ & & $-0.7 \%$ & & $-0.3 \%$ & & $-0.1 \%$ & $-0.4 \%$ & & $0.3 \%$ & \\
\hline 47. & Tradables & $1-3$ & $3.7 \%$ & & $-1.0 \%$ & & $-1.0 \%$ & & $0.0 \%$ & $-0.9 \%$ & & $0.4 \%$ & \\
\hline 48. & Non-trade & 49 & $-0.4 \%$ & & $-0.4 \%$ & & $0.2 \%$ & & $0.1 \%$ & $0.0 \%$ & & $0.3 \%$ & \\
\hline 49. & Mining & 2 & $13.4 \%$ & & $1.7 \%$ & & $-3.1 \%$ & & $-1.3 \%$ & $-0.8 \%$ & & $2.8 \%$ & \\
\hline 50. & Manufact & 3 & $0.5 \%$ & & $-1.1 \%$ & & $-1.1 \%$ & & $0.2 \%$ & $-1.1 \%$ & & $-0.1 \%$ & \\
\hline 51. & Light manf & $301-302,391$ & $-0.9 \%$ & & $-1.4 \%$ & & $-0.7 \%$ & & $3.6 \%$ & $0.8 \%$ & & $-0.3 \%$ & \\
\hline $\begin{array}{l}52 . \\
53 .\end{array}$ & $\begin{array}{l}\text { Heavy manf } \\
\text { Tech manf }\end{array}$ & $\begin{array}{l}323,331-355 \\
324-326,356-387,392\end{array}$ & $\begin{array}{l}2.3 \% \\
-0.2 \%\end{array}$ & & $\begin{array}{l}-1.0 \% \\
-1.1 \%\end{array}$ & & $\begin{array}{l}-2.1 \% \\
-0.3 \%\end{array}$ & & $\begin{array}{l}-1.1 \% \\
-1.0 \%\end{array}$ & $\begin{array}{l}-2.1 \% \\
-1.3 \%\end{array}$ & & $\begin{array}{l}0.0 \% \\
-0.1 \%\end{array}$ & \\
\hline
\end{tabular}

Source: TIPS South African Standardised Industrial Data Base and own calculations 
Industries with a distinctly negative price effect during the second half of the 1990s are gold (row 40), basic metals (rows 41- 42) and textiles (row 44). In these sectors the consumer price increases by far outstripped the producer price increase captured by labour which had a negative effect on real wage growth.

The net effect of all components is shown in the last table. It can be seen that on average (row 46) real wage growth was robust in the 1970s than dropped off a bit during the 1980s but came back again during the 1990s, especially during the second half. Except for the 1970s nontradables have recorded higher real wage growth than tradables, while the boom in gold and coal ensured higher real wage growth for tradables during the 1970s. 
Table A 11: Real Wage Growth

\begin{tabular}{|c|c|c|c|c|c|c|c|c|c|c|c|c|c|}
\hline $\mathrm{Nr}$ & Description & SIC & $\begin{array}{c}1970 \mathrm{~s} \\
1\end{array}$ & $\begin{array}{c}\text { rank } \\
2\end{array}$ & $\begin{array}{c}1980 \mathrm{~s} \\
3\end{array}$ & $\begin{array}{c}\text { rank } \\
4\end{array}$ & $\begin{array}{l}1^{\text {shhalf }} 90 \mathrm{~s} \\
5\end{array}$ & $\begin{array}{c}\text { rank } \\
6\end{array}$ & $\begin{array}{c}2^{\text {nd }} \text { half } 90 \mathrm{~s} \\
7\end{array}$ & $\begin{array}{c}\text { full 1990s } \\
8\end{array}$ & $\begin{array}{c}\text { rank } \\
9\end{array}$ & $\begin{array}{c}\text { full period } \\
10\end{array}$ & $\begin{array}{c}\text { rank } \\
11\end{array}$ \\
\hline $\begin{array}{l}1 . \\
2 .\end{array}$ & $\begin{array}{l}\text { TV \& comms equipm } \\
\text { Tobacco }\end{array}$ & $\begin{array}{l}371-373 \\
306\end{array}$ & $\begin{array}{l}0.0 \% \\
4.9 \%\end{array}$ & $\begin{array}{c}32 \\
9\end{array}$ & $\begin{array}{l}1.3 \% \\
-1.3 \%\end{array}$ & $\begin{array}{l}18 \\
34\end{array}$ & $\begin{array}{l}1.1 \% \\
1.2 \%\end{array}$ & $\begin{array}{l}31 \\
30\end{array}$ & $\begin{array}{l}13.1 \% \\
9.8 \%\end{array}$ & $\begin{array}{l}3.5 \% \\
3.8 \%\end{array}$ & $\begin{array}{l}19 \\
14\end{array}$ & $\begin{array}{l}1.6 \% \\
2.1 \%\end{array}$ & $\begin{array}{l}25 \\
18\end{array}$ \\
\hline 3. & Communication & 75 & $-2.0 \%$ & 42 & $2.8 \%$ & 8 & $2.3 \%$ & 23 & $9.8 \%$ & $6.4 \%$ & 6 & $2.1 \%$ & 20 \\
\hline 4. & Other mining & $22 / 24 / 25 / 29$ & $9.5 \%$ & 3 & $0.3 \%$ & 21 & $13.2 \%$ & 1 & $9.5 \%$ & $9.6 \%$ & 1 & $4.7 \%$ & 3 \\
\hline 5. & Finance \& insurance & $81-82$ & $0.8 \%$ & 27 & $1.9 \%$ & 14 & $3.1 \%$ & 16 & $9.2 \%$ & $4.3 \%$ & 11 & $1.6 \%$ & 22 \\
\hline $\begin{array}{l}6 . \\
7 .\end{array}$ & $\begin{array}{l}\text { Construction } \\
\text { Plastic products }\end{array}$ & $\begin{array}{l}51 \\
338\end{array}$ & $\begin{array}{l}-1.7 \% \\
7.4 \%\end{array}$ & $\begin{array}{c}41 \\
4\end{array}$ & $\begin{array}{l}1.6 \% \\
-1.2 \%\end{array}$ & $\begin{array}{l}16 \\
31\end{array}$ & $\begin{array}{l}2.1 \% \\
-0.9 \%\end{array}$ & $\begin{array}{l}24 \\
40\end{array}$ & $\begin{array}{l}8.6 \% \\
8.3 \%\end{array}$ & $\begin{array}{l}5.3 \% \\
2.8 \%\end{array}$ & $\begin{array}{c}9 \\
24\end{array}$ & $\begin{array}{l}1.6 \% \\
1.2 \%\end{array}$ & $\begin{array}{l}21 \\
27\end{array}$ \\
\hline 8. & Business services & 83-88 & $-3.5 \%$ & 45 & $-2.8 \%$ & 40 & $2.9 \%$ & 17 & $8.0 \%$ & $5.8 \%$ & 8 & $0.2 \%$ & 36 \\
\hline 9. & Cat $\&$ accomm serv & 64 & $-0.3 \%$ & 36 & $4.2 \%$ & 5 & $3.5 \%$ & 11 & $7.9 \%$ & $4.9 \%$ & 10 & $3.1 \%$ & 8 \\
\hline 10. & Rubber products & 337 & $2.9 \%$ & 15 & $-1.2 \%$ & 33 & $2.1 \%$ & 25 & $7.8 \%$ & $1.1 \%$ & 37 & $0.9 \%$ & 30 \\
\hline $\begin{array}{l}11 . \\
12 .\end{array}$ & $\begin{array}{l}\text { Civil eng } \\
\text { Beverages }\end{array}$ & $\begin{array}{l}52-53 \\
305\end{array}$ & $\begin{array}{l}5.0 \% \\
3.1 \%\end{array}$ & $\begin{array}{c}7 \\
13\end{array}$ & $\begin{array}{l}-5.3 \% \\
0.1 \%\end{array}$ & $\begin{array}{l}45 \\
22\end{array}$ & $\begin{array}{l}-3.6 \% \\
1.5 \%\end{array}$ & $\begin{array}{l}44 \\
29\end{array}$ & $\begin{array}{l}7.7 \% \\
7.6 \%\end{array}$ & $\begin{array}{l}2.4 \% \\
4.3 \%\end{array}$ & $\begin{array}{l}30 \\
12\end{array}$ & $\begin{array}{l}-0.4 \% \\
2.1 \%\end{array}$ & $\begin{array}{l}43 \\
19\end{array}$ \\
\hline 13. & Transport & $71-74$ & $-0.3 \%$ & 34 & $-0.6 \%$ & 26 & $6.8 \%$ & 5 & $7.1 \%$ & $6.8 \%$ & 4 & $2.3 \%$ & 16 \\
\hline 14. & Glass and products & 341 & $3.7 \%$ & 11 & $0.5 \%$ & 20 & $3.2 \%$ & 15 & $6.8 \%$ & $5.8 \%$ & 7 & $3.1 \%$ & 9 \\
\hline 15. & Gold & 23 & $10.7 \%$ & 2 & $0.5 \%$ & 19 & $-2.7 \%$ & 43 & $6.3 \%$ & $2.7 \%$ & 26 & $2.6 \%$ & 14 \\
\hline $\begin{array}{l}16 . \\
17 .\end{array}$ & $\begin{array}{l}\text { Textiles } \\
\text { Wearing apparel }\end{array}$ & $\begin{array}{l}311-312 \\
313-315\end{array}$ & $\begin{array}{l}2.3 \% \\
-1.4 \%\end{array}$ & $\begin{array}{l}21 \\
39\end{array}$ & $\begin{array}{l}-0.8 \% \\
-1.1 \%\end{array}$ & $\begin{array}{l}28 \\
30\end{array}$ & $\begin{array}{l}1.8 \% \\
0.7 \%\end{array}$ & $\begin{array}{l}27 \\
33\end{array}$ & $\begin{array}{l}6.3 \% \\
5.9 \%\end{array}$ & $\begin{array}{l}3.4 \% \\
1.9 \%\end{array}$ & $\begin{array}{l}20 \\
32\end{array}$ & $\begin{array}{l}1.2 \% \\
0.2 \%\end{array}$ & $\begin{array}{l}28 \\
34\end{array}$ \\
\hline 18. & Electrical mach & $361-366$ & $3.2 \%$ & 12 & $-2.8 \%$ & 39 & $2.5 \%$ & 20 & $5.6 \%$ & $3.1 \%$ & 22 & $0.5 \%$ & 33 \\
\hline 19. & Non-met min & 342 & $2.2 \%$ & 22 & $1.9 \%$ & 15 & $4.2 \%$ & 8 & $5.5 \%$ & $3.7 \%$ & 16 & $2.4 \%$ & 15 \\
\hline 20. & Food & $301-304$ & $2.3 \%$ & 20 & $-0.1 \%$ & 24 & $2.4 \%$ & 21 & $5.3 \%$ & $2.7 \%$ & 25 & $1.6 \%$ & 23 \\
\hline $\begin{array}{l}21 . \\
22 .\end{array}$ & $\begin{array}{l}\text { Paper and products } \\
\text { Other chemicals }\end{array}$ & $\begin{array}{l}323 \\
335-336\end{array}$ & $\begin{array}{l}2.4 \% \\
6.8 \%\end{array}$ & $\begin{array}{c}19 \\
5\end{array}$ & $\begin{array}{l}-0.1 \% \\
3.4 \%\end{array}$ & $\begin{array}{c}23 \\
6\end{array}$ & $\begin{array}{l}2.9 \% \\
-0.2 \%\end{array}$ & $\begin{array}{l}18 \\
37\end{array}$ & $\begin{array}{l}5.0 \% \\
4.8 \%\end{array}$ & $\begin{array}{l}3.6 \% \\
2.4 \%\end{array}$ & $\begin{array}{l}18 \\
27\end{array}$ & $\begin{array}{l}1.6 \% \\
3.7 \%\end{array}$ & $\begin{array}{c}24 \\
5\end{array}$ \\
\hline 23. & Mot veh \& access & $381-383$ & $-1.2 \%$ & 38 & $3.3 \%$ & 7 & $-0.5 \%$ & 39 & $4.5 \%$ & $1.6 \%$ & 35 & $1.5 \%$ & 26 \\
\hline 24. & Basic iron \& steel & 351 & $4.9 \%$ & 8 & $2.0 \%$ & 11 & $3.2 \%$ & 14 & $4.5 \%$ & $3.8 \%$ & 15 & $2.8 \%$ & 12 \\
\hline 25. & Water supply & 42 & $-2.2 \%$ & 44 & $-4.3 \%$ & 43 & $8.3 \%$ & 4 & $4.3 \%$ & $7.8 \%$ & 3 & $3.3 \%$ & 7 \\
\hline $\begin{array}{l}26 . \\
27 .\end{array}$ & $\begin{array}{l}\text { Other producers } \\
\text { Furniture }\end{array}$ & $\begin{array}{l}98 \\
391\end{array}$ & $\begin{array}{l}-2.0 \% \\
1.3 \%\end{array}$ & $\begin{array}{l}43 \\
25\end{array}$ & $\begin{array}{l}-1.6 \% \\
-4.8 \%\end{array}$ & $\begin{array}{l}35 \\
44\end{array}$ & $\begin{array}{l}3.6 \% \\
5.6 \%\end{array}$ & $\begin{array}{c}10 \\
6\end{array}$ & $\begin{array}{l}4.3 \% \\
4.3 \%\end{array}$ & $\begin{array}{l}6.7 \% \\
2.1 \%\end{array}$ & $\begin{array}{c}5 \\
31\end{array}$ & $\begin{array}{l}0.7 \% \\
-0.9 \%\end{array}$ & $\begin{array}{l}32 \\
44\end{array}$ \\
\hline 28. & Prof \& sci equipm & $374-376$ & $2.7 \%$ & 16 & $-0.4 \%$ & 25 & $-1.5 \%$ & 42 & $4.1 \%$ & $0.3 \%$ & 41 & $0.2 \%$ & 37 \\
\hline 29. & Wood and products & $321-322$ & $0.3 \%$ & 30 & $-0.7 \%$ & 27 & $0.2 \%$ & 35 & $3.5 \%$ & $2.4 \%$ & 29 & $0.2 \%$ & 35 \\
\hline 30. & Print, publ \& rec media & $324-326$ & $-0.6 \%$ & 37 & $-1.9 \%$ & 36 & $0.6 \%$ & 34 & $3.3 \%$ & $0.6 \%$ & 39 & $-0.2 \%$ & 40 \\
\hline $\begin{array}{l}31 . \\
32 .\end{array}$ & $\begin{array}{l}\text { Electricity } \\
\text { Agriculture }\end{array}$ & $\begin{array}{l}41 \\
1\end{array}$ & $\begin{array}{l}-0.3 \% \\
2.5 \%\end{array}$ & $\begin{array}{l}35 \\
18\end{array}$ & $\begin{array}{l}5.6 \% \\
-1.2 \%\end{array}$ & $\begin{array}{c}2 \\
32\end{array}$ & $\begin{array}{l}4.7 \% \\
3.4 \%\end{array}$ & $\begin{array}{c}7 \\
13\end{array}$ & $\begin{array}{l}3.1 \% \\
2.7 \%\end{array}$ & $\begin{array}{l}4.0 \% \\
3.0 \%\end{array}$ & $\begin{array}{l}13 \\
23\end{array}$ & $\begin{array}{l}3.5 \% \\
0.8 \%\end{array}$ & $\begin{array}{c}6 \\
31\end{array}$ \\
\hline 33. & Soc serv: medical & 93 & $-1.6 \%$ & 40 & $6.6 \%$ & 1 & $9.2 \%$ & 2 & $2.5 \%$ & $8.6 \%$ & 2 & $6.1 \%$ & 1 \\
\hline 34. & Machinery & $356-359$ & $2.6 \%$ & 17 & $-3.6 \%$ & 42 & $-1.1 \%$ & 41 & $2.3 \%$ & $0.2 \%$ & 42 & $-0.2 \%$ & 41 \\
\hline 35. & Other manufact & 392-393 & $0.6 \%$ & 29 & $-1.0 \%$ & 29 & $0.2 \%$ & 36 & $1.8 \%$ & $0.3 \%$ & 40 & $-0.1 \%$ & 39 \\
\hline $\begin{array}{l}36 . \\
37 .\end{array}$ & $\begin{array}{l}\text { Petroleum products } \\
\text { Metal products }\end{array}$ & $\begin{array}{l}331-333 \\
353-355\end{array}$ & $\begin{array}{l}3.0 \% \\
4.0 \%\end{array}$ & $\begin{array}{l}14 \\
10\end{array}$ & $\begin{array}{l}4.8 \% \\
-2.9 \%\end{array}$ & $\begin{array}{c}3 \\
41\end{array}$ & $\begin{array}{l}2.4 \% \\
2.0 \%\end{array}$ & $\begin{array}{l}22 \\
26\end{array}$ & $\begin{array}{l}1.7 \% \\
1.5 \%\end{array}$ & $\begin{array}{l}2.4 \% \\
1.8 \%\end{array}$ & $\begin{array}{l}28 \\
33\end{array}$ & $\begin{array}{l}3.8 \% \\
0.0 \%\end{array}$ & $\begin{array}{c}4 \\
38\end{array}$ \\
\hline 38. & Basic chemicals & 334 & $0.2 \%$ & 31 & $4.4 \%$ & 4 & $-0.4 \%$ & 38 & $0.8 \%$ & $0.8 \%$ & 38 & $3.0 \%$ & 10 \\
\hline 39. & Leather and products & 316 & $0.7 \%$ & 28 & $-2.6 \%$ & 38 & $3.4 \%$ & 12 & $-0.2 \%$ & $1.8 \%$ & 34 & $-0.3 \%$ & 42 \\
\hline 40. & Soc serv: other & 9496 & $-0.2 \%$ & 33 & $2.0 \%$ & 12 & $3.8 \%$ & 9 & $-0.5 \%$ & $3.7 \%$ & 17 & $2.9 \%$ & 11 \\
\hline $\begin{array}{l}41 . \\
42 .\end{array}$ & $\begin{array}{l}\text { Coal mining } \\
\text { Footwear }\end{array}$ & $\begin{array}{l}21 \\
317\end{array}$ & $\begin{array}{l}14.3 \% \\
2.1 \%\end{array}$ & $\begin{array}{c}1 \\
23\end{array}$ & $\begin{array}{l}2.2 \% \\
-2.5 \%\end{array}$ & $\begin{array}{l}10 \\
37\end{array}$ & $\begin{array}{l}1.5 \% \\
-3.6 \%\end{array}$ & $\begin{array}{l}28 \\
45\end{array}$ & $\begin{array}{l}-1.9 \% \\
-3.4 \%\end{array}$ & $\begin{array}{l}1.4 \% \\
-3.1 \%\end{array}$ & $\begin{array}{l}36 \\
45\end{array}$ & $\begin{array}{l}5.2 \% \\
-1.0 \%\end{array}$ & $\begin{array}{c}2 \\
45\end{array}$ \\
\hline 43. & Other trnsp equipm & $384-387$ & $6.3 \%$ & 6 & $2.0 \%$ & 13 & $1.1 \%$ & 32 & $-3.8 \%$ & $-2.8 \%$ & 44 & $1.0 \%$ & 29 \\
\hline 44. & Trade & $61-63$ & $1.2 \%$ & 26 & $1.5 \%$ & 17 & $2.8 \%$ & 19 & $-3.8 \%$ & $-0.1 \%$ & 43 & $2.2 \%$ & 17 \\
\hline 45. & Basic nonferr met & 352 & $1.9 \%$ & 24 & $2.6 \%$ & 9 & $9.0 \%$ & 3 & $-3.8 \%$ & $3.3 \%$ & 21 & $2.7 \%$ & 13 \\
\hline $\begin{array}{l}46 . \\
47 .\end{array}$ & $\begin{array}{l}\text { Total val add at fct cst } \\
\text { Tradables }\end{array}$ & $\begin{array}{l}1-9 \\
1-3\end{array}$ & $\begin{array}{l}2.4 \% \\
4.8 \%\end{array}$ & & $\begin{array}{l}0.4 \% \\
0.1 \%\end{array}$ & & $\begin{array}{l}2.6 \% \\
1.3 \%\end{array}$ & & $\begin{array}{l}4.8 \% \\
4.2 \%\end{array}$ & $\begin{array}{l}3.7 \% \\
2.5 \%\end{array}$ & & $\begin{array}{l}2.1 \% \\
1.9 \%\end{array}$ & \\
\hline 48. & Non-trade & 49 & $0.2 \%$ & & $0.5 \%$ & & $3.5 \%$ & & $4.3 \%$ & $4.2 \%$ & & $2.0 \%$ & \\
\hline 49. & Mining & 2 & $10.8 \%$ & & $0.6 \%$ & & $1.9 \%$ & & $7.0 \%$ & $4.8 \%$ & & $3.5 \%$ & \\
\hline 50. & Manufact & 3 & $2.6 \%$ & & $-0.4 \%$ & & $1.0 \%$ & & $3.9 \%$ & $1.8 \%$ & & $1.1 \%$ & \\
\hline 51. & Light manf & 301-302, 391 & $2.0 \%$ & & $-0.7 \%$ & & $1.3 \%$ & & $5.8 \%$ & $2.4 \%$ & & $1.1 \%$ & \\
\hline 52. & Heavy manf & $323,331-355$ & $3.7 \%$ & & $0.8 \%$ & & $1.6 \%$ & & $2.7 \%$ & $2.1 \%$ & & $1.8 \%$ & \\
\hline 53. & Tech manf & $324-326,356-387,392$ & $1.8 \%$ & & $-1.3 \%$ & & $0.0 \%$ & & $3.8 \%$ & $1.1 \%$ & & $0.3 \%$ & \\
\hline
\end{tabular}

Source: TIPS South African Standardised Industrial Data Base and own calculations 
Manufacturing as a whole (row 43) scored a much lower but still positive real wage growth during the 1990s, mainly due to manufacturing and technology rich manufacturing, such as TV and consumer electronics (row 1), plastics producers (row 7), and beverages (row 12). Other manufacturing industries that recorded negative real wage growth are basic non-ferrous metals (row 45), other tansport equipment (row 43) and footwear (row 42. The service sectors have experience positive and rising real wage growth over the whole period of observation, which is mainly due to the communications sector and to a lesser degree the social service providers.

How does this relate to the trade-off between employment growth and real wage growth? In order to investigate this issue we continue by presenting employment elasticities, defined here as the ratio of employment growth and growth in real value added. The results are shown in the next table. 
Table A 12: Employment Elasticities

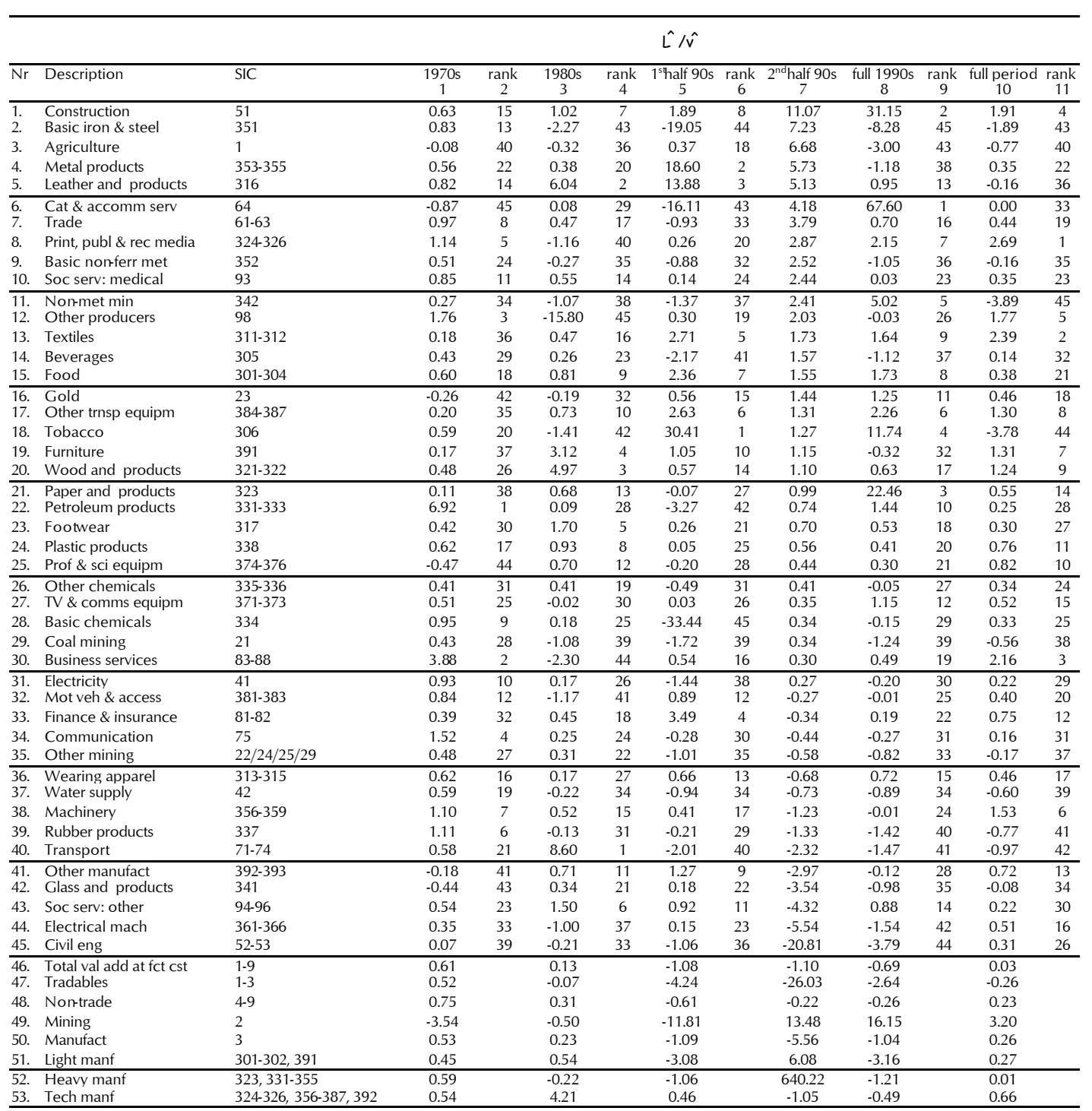

Source: TIPS South African Standardised Industrial Data Base and own calculations 
Similar to the employment growth rates shown in

Table A 7 above, the economy-wide employment elasticities have seen a steady decline into negative territory over the full period. While the elasticity was still positive during the 1970s, when a $1 \%$ increase in real value added resulted in a $0.6 \%$ increase in employment, the elasticity dropped to 0.13 during the 1980 s and was -0.7 during the 1990s. During the second half of the 1990s, the (formal sector) employment elasticity for the economy as a whole was 1.1, which means that for each $1 \%$ increase in value added, employment declined by $1.1 \%$. In the next row it can be seen that for tradables this was an incredible $260 \%$ decline and even the non-tradables showed a decline.

It should be noted that the employment elasticity can be somewhat deceptive in that it generate a positive number if both employment growth and growth in real value added are positive as well as when they are both negative. This typically explains why the elasticities for construction, basic iron and steel and agriculture (rows 1-3) are so highly positive. The question is whether this relationship will also hold during an expansionary phase in the mining sector.

Those sectors that have shown positive real increases in value added such as TV and electronics producers, plastics producers, finance and business services and communication (see top of Table A ) have shown low or negative employment elasticities during the second half of the 1990s (see rows 24, 27, 33 and 34 respectively). 